\title{
INVESTIGATION OF THE REGULATION OF EXPRESSION OF E. COLI COMMON PILUS SUBUNIT, ECPA, OF ENTEROHAEMORRHAGIC E. COLI 0157:H7 UNDER ACID STRESS
}

by

Hannah Tollman

Bachelor of Science, Winona State University, 2009

\author{
A thesis \\ presented to Ryerson University \\ in partial fulfillment of the \\ Requirements for the degree of \\ Master of Science \\ in the Program of \\ Molecular Science
}

Toronto, Ontario, Canada, 2013

(C) Hannah Tollman 2013 


\section{Author's Declaration}

I hereby declare that I am the sole author of this thesis. This is a true copy of the thesis, including any required final revisions, as accepted by my examiners.

I authorize Ryerson University to lend this thesis to other institutions or individuals for the purpose of scholarly research

I further authorize Ryerson University to reproduce this thesis by photocopying or by other means, in total or in part, at the request of other institutions or individuals for the purpose of scholarly research.

I understand that my thesis may be made electronically available to the public. 


\title{
INVESTIGATION OF THE REGULATION OF EXPRESSION OF E. COLI COMMON PILUS SUBUNIT, ECPA, OF ENTEROHAEMORRHAGIC E. COLI 0157:H7 UNDER ACID STRESS
}

\author{
Hannah Tollman \\ Master of Science, Molecular Science, Ryerson University, 2013
}

\begin{abstract}
Escherichia coli (EHEC) 0157:H7 is a pathogenic bacterial species that is most commonly linked to severe diarrhea, but is also the leading cause of the potentially fatal hemolytic-uremic syndrome (HUS). In order to establish infection in the colon, EHEC must endure different stresses encountered in the gastrointestinal (GI) tract, such as acid stress in the stomach, bile salt stress in the small intestine, and short-chain fatty acid (SCFA) stress in the colon. These bacteria are likely able to use GI stresses as indicators of their location, impacting gene expression of adhesion, motility, and virulence factors. The E. coli Common Pilus (ECP) has been shown to be an important factor for EHEC adhesion to epithelial cells, which is increased after either acid or SCFA stress. It has also been demonstrated via microarray that genes of this operon are upregulated after acid stress. The aim of this study is to determine how expression of the main subunit of this structure, EcpA, is regulated upon exposure of EHEC 0157:H7 to acid or SCFA-stress. Both transcriptional and translational regulation are hypothesized to be involved. Isogenic mutants have been constructed that lacked key regulators suspected to be important for each system. Two approaches are used to determine if the predicted regulatory systems are playing a role in response to stress: observing EcpA protein expression analysis through Western blotting with anti-EcpA antibodies, and examining differences in ecp operon promoter activity in regulatory mutants. In this study Western blots reconfirmed H-NS as a negative regulator of the ecp operon. However, beta-galactosidase assays show that H-NS does not modulate ecpA expression in direct response to acute acid stress. This suggests an alternate regulatory response in EHEC 0157:H7 to acute acid stress resulting in the upregulation of ecpA expression previously observed with microarray analysis.
\end{abstract}




\section{Acknowledgements}

It is with immense gratitude that I acknowledge the support and guidance of my supervisor, Dr. Debora Foster. Your encouragement, patience, and knowledge have helped me to complete this project. It wasn't always a straightforward journey, but it couldn't have happened at all without you.

I also thank Dr. Roberto Botelho and Dr. Kimberley Gilbride for serving on my supervisory committee. Your feedback was invaluable to my efforts and very much appreciated.

An enormous thank you to my friends and family, especially my parents: Bryan and Taali, Susan and Jim. Your love, support and patience while I was completing this work means the world to me, I truly could not have done this without you.

Last but not least, thank you to my fellow Molecular Science students as well as Ryerson faculty and staff member:. Seav-ly Tran, Yijing Yu, Ahferom Gebremedhin, Crystal Gadishaw Lue, Merlin Perez, Callista Yee, Shawn Clark, Grace Ha Eun Kim, Shannon Ho, Christopher Choy, Dr. Marie Killeen, Dr. Costin Antonescu, Dr. Anne Johnson, Miriam de Jong, Stephanie Grouios, Dulce Banegas, and Maria Landau. And of course Tracy Lackraj. 


\section{Table of Contents}

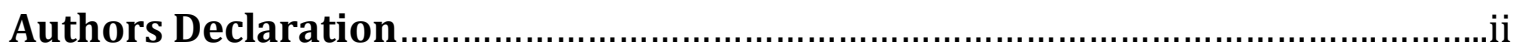

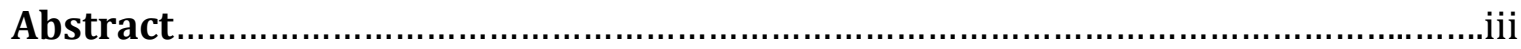

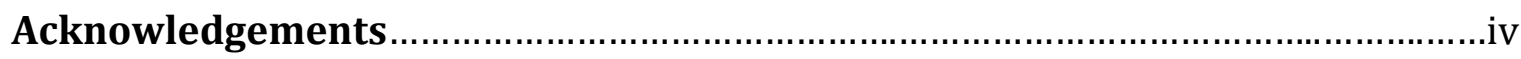

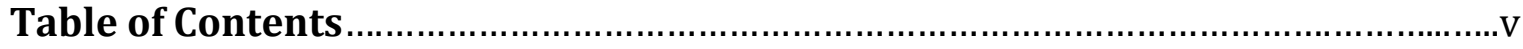

List of Tables.............................................................................................................

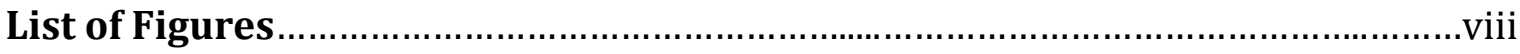

\section{INTRODUCTION}

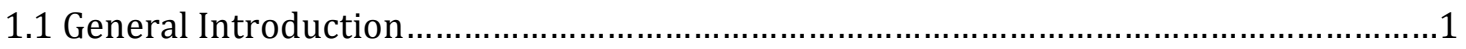

1.2 EHEC Infection and Pathogenic Mechanisms.............................................................

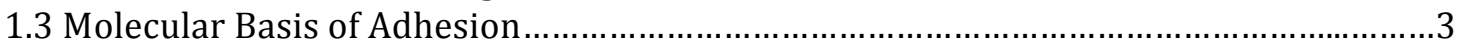

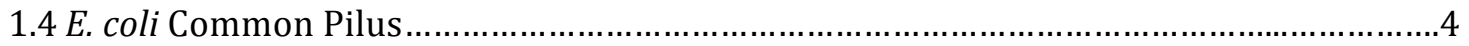

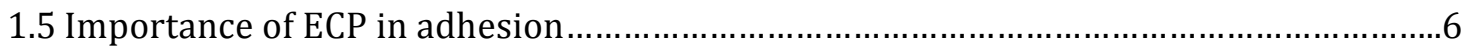

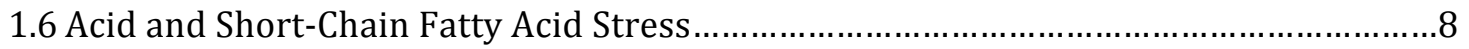

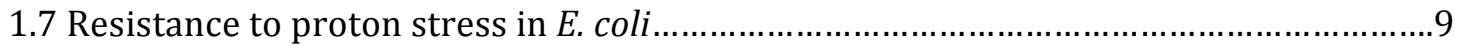

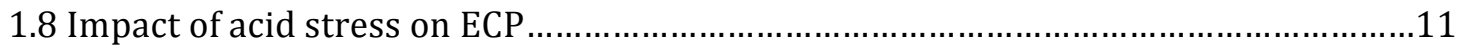

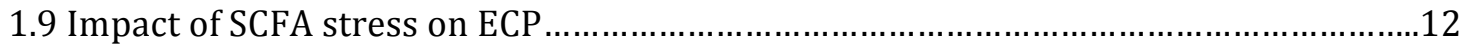

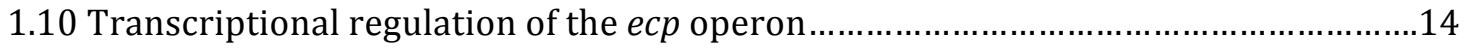

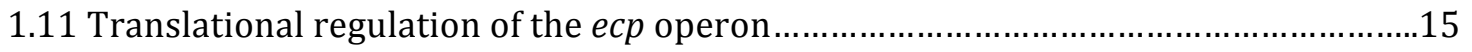

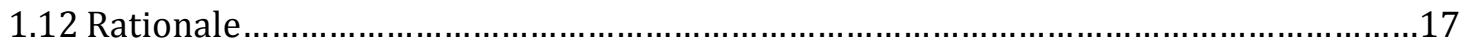

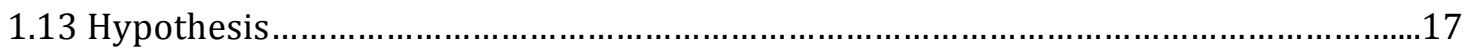

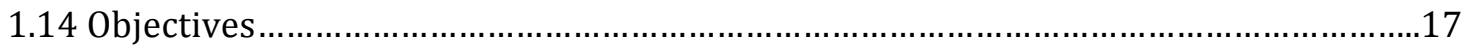

\section{MATERIALS AND METHODS}

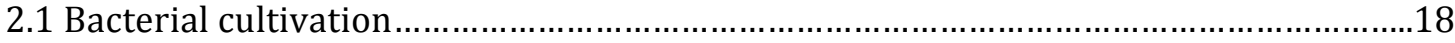

2.2 Creation of isogenic mutants

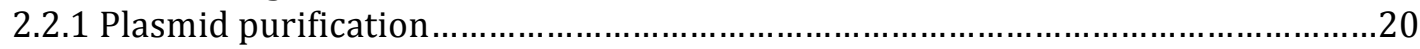

2.2.2 Primer design and PCR amplification of kanamycin resistance cassette...............20

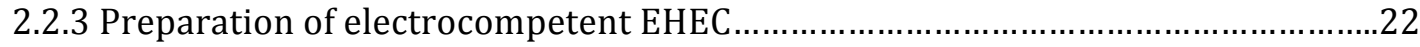

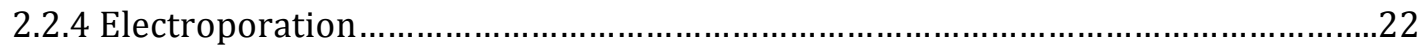

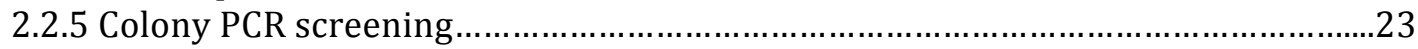

2.3 Construction of beta-galactosidase promoter fusion construct

2.3.1 Primer design and PCR amplification of ECP promoter region............................25

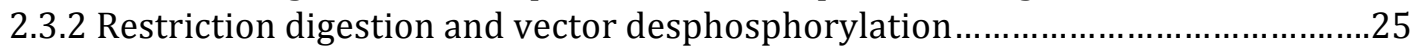

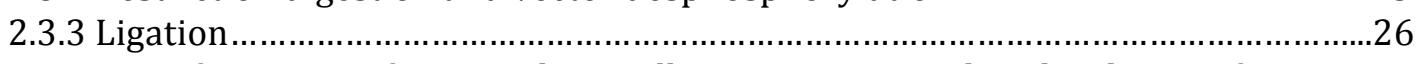

2.3.4 Transformation of TOP10 chemically competent E. coli and isolation of pMC1403-

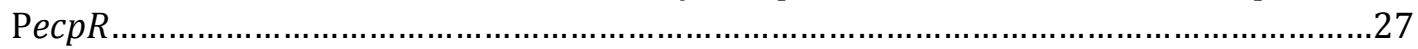

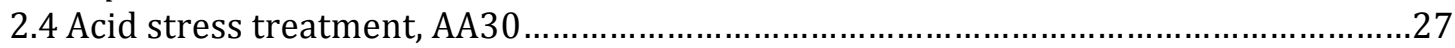

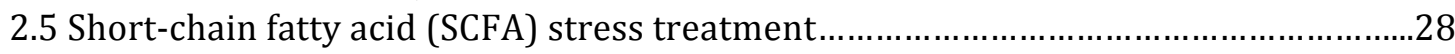

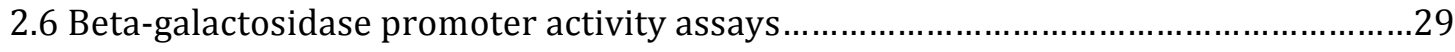

2.7 Western blotting

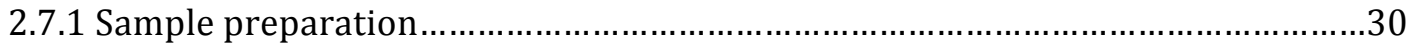




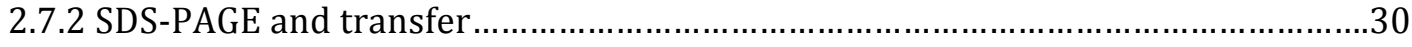

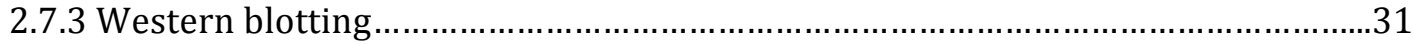

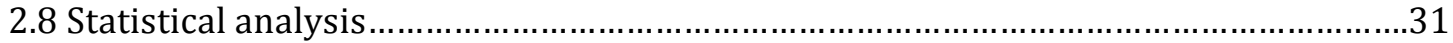

\section{RESULTS}

3.1 Construction of EDL933 isogenic mutants. .32

3.2 EcpA expression in E. coli 0157:H7 EDL933 and isogenic mutants.............................38

3.3 Construction of ecpR promoter fusion construct pMC1403-PecpR and subsequent

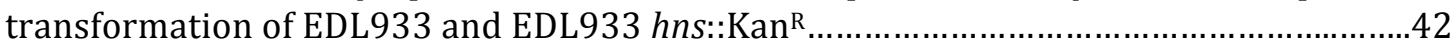

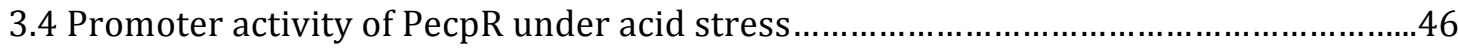

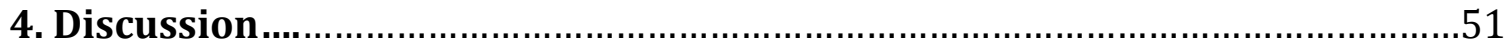

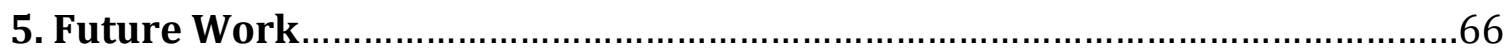

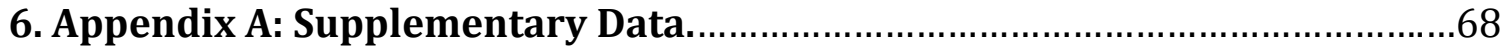

7. References 


\section{LIST OF TABLES}

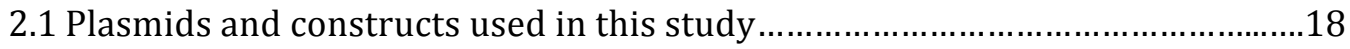

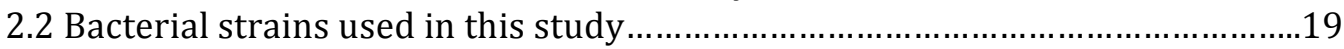

2.3 Standard antibiotic concentrations used in this study...................................19

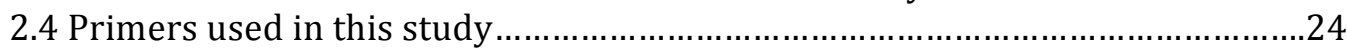

4.1 Impact of strain and culture conditions on EcpA expression.............................53

4.2 Impact of strain, culture conditions, and promoter region on ecp operon

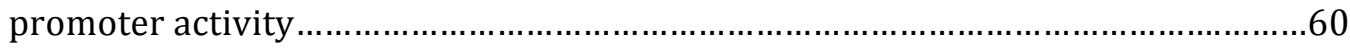




\section{LIST OF FIGURES}

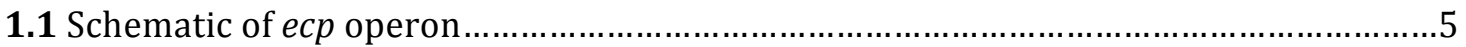

1.2 Schematic of chaperone/usher pathway pili assembly …………..............................

1.3 ECP in an important factor for EHEC adhesion to epithelial cells ..................................

1.4 Adhesion of EHEC is decreased significantly in the absence of EcpA............................

1.5 Schematic of Acid Resistance System 3 (AR3) ........................................................10

1.6 Microarray analysis of EHEC gene expression after acid stress...................................11

1.7 Exposure to acid stress increases EHEC ECP-mediated adhesion to epithelial cells...12

1.8 Exposure to 90mM SCFA stress increases EHEC ECP-mediated adhesion to epithelial

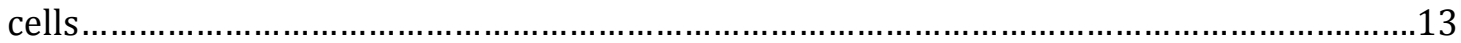

1.9 Schematic of ecp operon transcriptional regulation.................................................15

1.10 Schematic of hypothetical ecp operon translational regulation ..................................16

2.1 Overview of $\lambda$ red recombinase-mediated homologous recombination.......................21

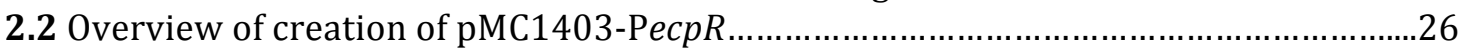

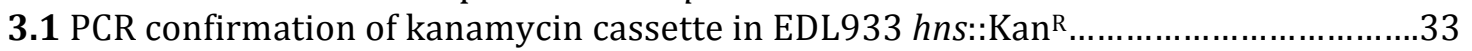

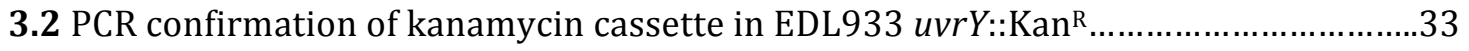

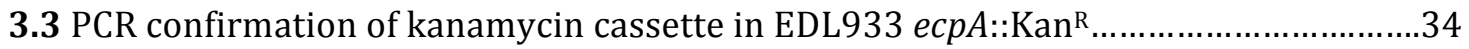

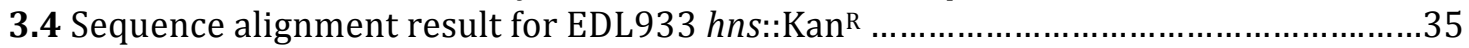

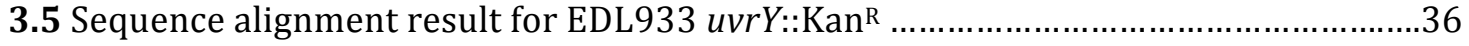

3.6 Sequence alignment result for EDL933 ecpA::Kan ${ }^{\mathrm{R}} \ldots \ldots \ldots \ldots \ldots \ldots \ldots \ldots \ldots \ldots \ldots \ldots \ldots \ldots \ldots \ldots \ldots \ldots . .37$

3.7 Western blotting of EcpA in EDL933 and EDL933 ecpA::Kann with $\alpha$-EcpA.................39

3.8 Western blotting of EcpA in EDL933 and EDL933 hns::Kan ${ }^{\mathrm{R}}$ with $\alpha$-EcpA....................40

3.9 Western blotting of EcpA in EDL933 and isogenic mutants with $\alpha$-EcpA A....................41

3.10 Sequence alignment result for pMC1403-Pecp $R \ldots \ldots \ldots \ldots \ldots \ldots \ldots \ldots \ldots \ldots \ldots \ldots \ldots \ldots \ldots \ldots \ldots \ldots \ldots . . .43$

3.11 PCR confirmation of transformation of EDL933 with pMC1403 and pMC1403-

PecpR

3.12 PCR confirmation of transformation of EDL933 hns:: $\operatorname{Kan}^{\mathrm{R}}$ with pMC1403 and

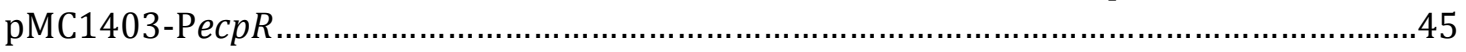

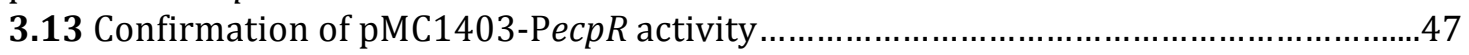

3.14 ecpR promoter activity in EDL933 after acid stress.............................................48

3.15 ecpR promoter activity in EDL933 hns::Kan ${ }^{\mathrm{R}}$ after acid stress..................................49

3.16 Effect of H-NS on ecpR promoter activity in EDL933 acid stress...............................50

4.1 Comparison of eсp operon promoter regions used for ecp operon transcriptional

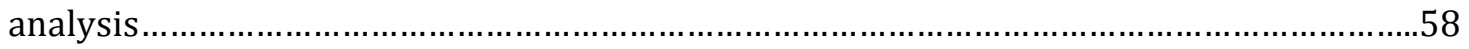

4.2 Potential mechanisms modulating ecpA expression in EHEC 0157:H7 under acid and SCFA stress. 


\section{Introduction}

\subsection{General Introduction}

Escherichia coli (E. coli) is a species of rod shaped, gram-negative bacteria that most frequently colonize the guts of the host organism ${ }^{7,45}$. There are many strains of $E$. coli found in many different host organisms. Most strains of $E$. coli are harmless and, in fact, share a symbiotic relationship with their host as commensal members of a diverse microflora ${ }^{45}$. There are others that have evolved the potential to cause serious illness upon infection, depending on the species of the host organism ${ }^{7}$ 45. The enterohaemorrhagic (EHEC) pathotype is one of the E. coli subsets known to be pathogenic to humans ${ }^{45}$.

E. coli $\mathrm{O} 157: \mathrm{H} 7$ is arguably the most well known serotype within the EHEC pathotype ${ }^{45,78}$. EHEC 0157:H7 was first identified in 1982 after being implicated as the cause of several outbreaks of food poisoning in humans, some of them fatal ${ }^{7,11,13,45}$. Those food poisoning incidents were traced back to the consumption of beef products that had not been cooked thoroughly, leaving the bacteria viable ${ }^{7,11}$. Anywhere from 150\% of cattle are colonized with EHEC O157:H7 at any given time, and those cattle shed the bacteria into their environment ${ }^{7,11,45}$. Processing of cattle for meat production allows for bacteria, such as EHEC, on the exterior surface of the cattle to come into contact with the interior tissues humans consume as meat; with many large-scale meat-processing plants currently in operation, there are ample opportunities for these accidentally contaminated products to make it to market ${ }^{11,45}$. EHEC O157:H7 outbreaks have also been traced back to dairy products, as well as contaminated produce ${ }^{7,11,45}$. The largest outbreak of EHEC O157:H7 infection, with 7966 confirmed cases, occurred in 1996 in Japan and was traced back to contaminated radish sprouts ${ }^{7,45}$. Studies have found that this type of contamination of produce can be linked back to exposure to feces of EHEC colonized cattle ${ }^{7,11,45}$. 


\subsection{EHEC Infection and Pathogenic Mechanisms}

Human infection with EHEC O157:H7 is associated with many different symptoms that range in severity and can present in varied combinations. The most common symptoms and developments stemming from EHEC O157:H7 infection include diarrhea, hemorrhagic colitis (HC), and hemolytic uremic syndrome (HUS) $7,11,13,45,48,61,66,75$. The majority of infections will present as a bout of diarrhea without blood, and are resolved without medical intervention. More severe infections will proceed to $\mathrm{HC}$, characterized by abdominal cramping, vomiting, and bloody diarrhea. Infected individuals who progress to $\mathrm{HC}$ have a much higher risk of developing HUS, a condition which can result in renal failure, and in some cases death ${ }^{7,11,13,45,61}$.

EHEC 0157:H7 infection includes two important and relatively unique events as compared to other enteric pathogens and E. coli serotypes: intimate attachment to host cells and the subsequent development of attaching and effacing (A/E) lesions, and the production of Shiga-like toxins (Stx1 and Stx2) $)^{7,45,48,66,75}$. In EHEC, intimate attachment to host cells is associated with a pathogenicity island, known as the locus of enterocyte effacement (LEE), which is composed of LEE operons 1-5. LEE operons 1-3 encode a type III secretion system (TTSS). This TTSS acts as a molecular syringe that EHEC uses to inject effector molecules into target host cells $\mathrm{s}^{45,66,75}$. LEE4 encodes many of the effector molecules that are injected into host cells ${ }^{48}$. LEE5 encodes both the translocated intimin receptor (Tir) and it's specific bacterial adhesin, intimin ${ }^{48}$. Tir is a protein, expressed in the bacteria, that integrates itself into the host cell membrane. Tir then serves as a receptor that is specifically recognized by an intimin, present on the surface of the bacterial cell, leading to intimate adhesion of the bacteria to its host ${ }^{17,22,23,45,48,66}$. Along with this intimate binding, the effector molecules are also able to "hijack" cellsignaling pathways of the host cell, leading to a rearrangement of actin filaments in the host cell under the bacteria such that the host cell surface alters to form a pedestal under the bacteria ${ }^{17,22,23,48,52,66}$. These structures are commonly referred to as attaching and effacement lesions as they are characterized by their smoothing of the normally microvilli-coated enterocyte surface ${ }^{45,75}$. 
This colonization of columnar epithelial cells in the colon is the cause of host cell damage and can lead to the development of $\mathrm{HC}^{7,45,48}$. While this colonization is in itself damaging, it also the precursor event by which infected individuals develop one of the more severe conditions associated with EHE; it is the release of Shiga-like toxins by colonized EHEC O157:H7 that promotes progression to HUS ${ }^{45}$. EHEC O157:H7 strains carry one or both Shiga-like toxins, Stx-1 or Stx $-2^{7,45}$. Both variations function in the same manner as Shiga toxin produced in virulent Shigella strains ${ }^{7}$. Each individual toxin is composed of an A subunit and five identical B subunits, with the A subunit serving as the active form of the $\operatorname{toxin}^{45}$. The $\mathrm{B}$ subunits bind globotriaosylceramide (Gb3) receptors, present in high numbers in human renal tissue, resulting in uptake of the A subunit ${ }^{45}$. Once internalized, the A subunit inhibits the eukaryotic $60 \mathrm{~S}$ ribosomal subunit, preventing continued protein synthesis in the affected cell, resulting in cellular death ${ }^{45}$.

\subsection{Molecular Basis of Adhesion}

It is important though for these bacteria to first colonize their host organism so that they can establish a sizable population capable of infection. While EHEC O157:H7 has been demonstrated to have a low infectious dose, 10-50 organisms are enough to cause infection; the number that survives to the point of colonization is even smaller ${ }^{7,11,45,48}$. Thus in order to produce sufficient amounts of toxin to impact the host, the bacterial count must increase to cause illness ${ }^{11,45,48}$. This is where fimbria, the structures that will serve as the main focus of this research, come into play. Fimbria, or pili, are hair-like structures that are present on the surface of many different bacterial species and can play an important role in receptor-specific adherence of bacteria to hostcells ${ }^{9,32,46,56,75}$. Because there are pili that are capable of exchanging genetic information between bacteria, the alternate term, fimbria, is used to discuss specifically pili that serve exclusively as adhesins, whether to host cells, abiotic surfaces, or other bacteria ${ }^{56}$. 


\subsection{E. coli Common Pilus (ECP)}

Of particular interest for this study is an E. coli fimbrial structure known as the $E$. coli common pilus (ECP) or, alternatively, as Mat fimbria ${ }^{43,57,58}$. The highly conserved ecp operon, that encodes the components of ECP pili, is present in the genome of most strains of $E$. coli, however expression levels are not consistent across the species, and are

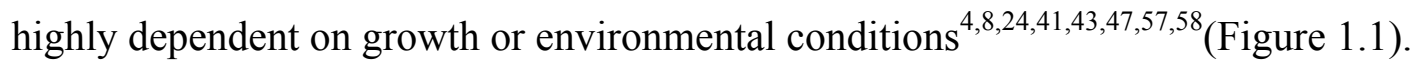

This fimbrial structure follows the chaperone/usher pathway of assembly, a pathway that has already been well established with E. coli Type 1 pili as a model $^{9,24,32,46,57}$. The basic structural idea of these chaperone/usher fimbria is that they are multimeric repeats of a major pilin subunit that extend outwards from the bacterial cell surface, and which are "capped off" with a different pilin subunit that contains an adhesin domain capable of recognizing and adhering to a specific receptor on a host cell ${ }^{9,24,32}$ (Figure 1.2).The subunits are transferred from the cytoplasm to a periplasmic chaperone protein that initiates a conformational folding of the subunit proteins before delivering the subunits to a membrane bound usher protein, allowing the subunits to exit the periplasmic space as they join the bottom of the growing fimbria ${ }^{9,24,32}$.

The ecp operon is comprised of six genes: ecpR, ecp $A, \operatorname{ecp} B, \operatorname{ecp} C, \operatorname{ecp} D$, and ecp $E^{24,57}$. EcpA is the major pilin subunit for ECP and is also referred to and known as $m a t B$ or $y a g Z^{24,27,43,57,58}$. This study preferentially refers to ecp $A$. For the other five genes in the ecp operon, four constitute the chaperone/usher proteins, and their roles are more specifically defined below (Figure 1.1). The last gene, ecpD, encodes the minor adhesin subunit of $\mathrm{ECP}^{24}$. 


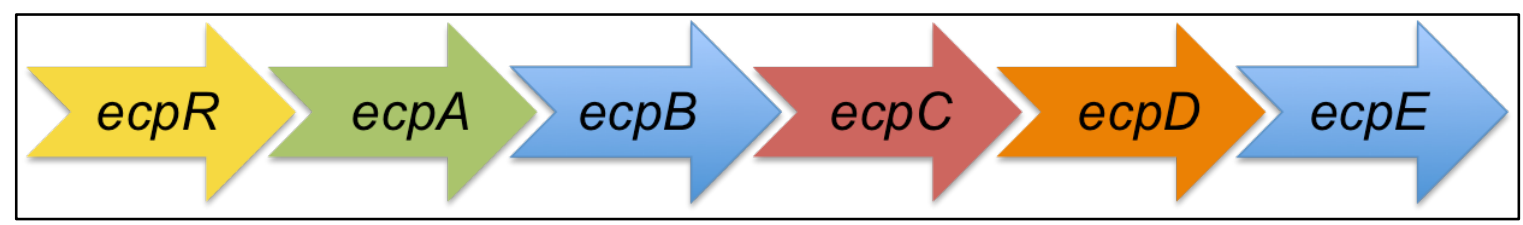

Figure 1.1: Schematic of ecp operon. ecpR is the gene for an operon specific promoter, еср$A$ is the gene for the major pilin subunit of the pilus, есрB is the gene for one of two chaperones, ecp $C$ is the gene for the usher, ecpD is the gene for the adhesin tip subunit, and ecp $E$ is the gene for the second chaperone. Image adapted from 57.

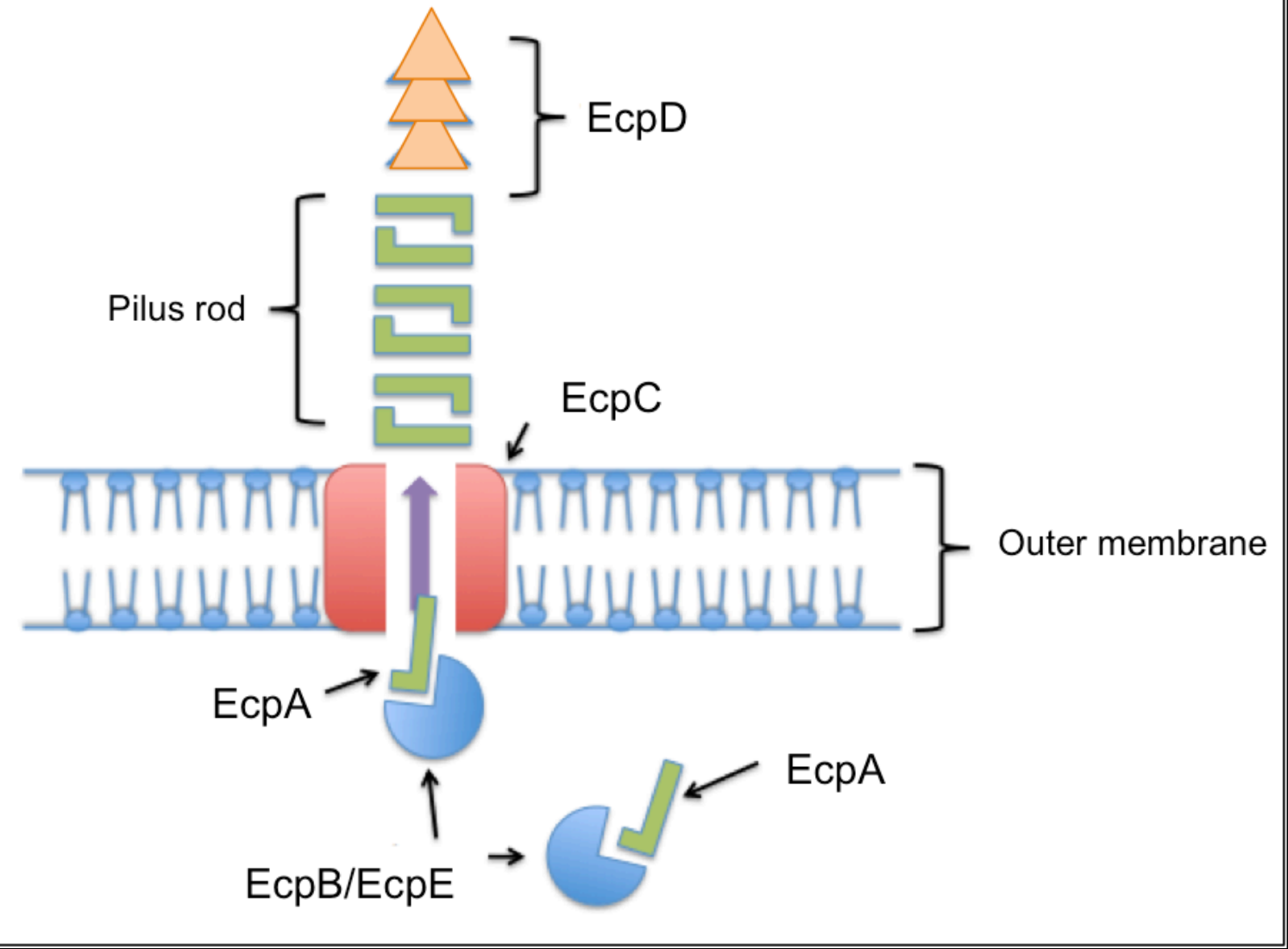

Figure 1.2: Schematic of chaperone/usher pathway pili assembly. Monomers of the major subunit undergo a conformational fold to allow for the formation of a multimer, which accounts for the majority of the structure. A specialized adhesin tip allows for receptor recognition and aids in adhesion to host cells. 


\subsection{Role for ECP in adhesion}

Previous reports have provided strong, multi-faceted evidence that ECP is an important adhesion factor for $E$. coli ${ }^{4,24,27,42,58,64}$. Adhesion assays and microscopy have demonstrated that isogenic EHEC mutants lacking ecpA show a significant decrease in adhesion to cultured HEp-2 and HeLa cells (Figures 1.3, 1.4), as well as to neighboring cells in microconlonies ${ }^{24,27,58}$. Similarly, in newborn meningitis-associated E. coli (NMEC, clinical isolate IHE 3034) ECP was found to promote adhesion to abiotic surfaces, plastic or glass, through biofilm formation ${ }^{42}$. ECP was shown to be important for both early biofilm development, and as an important component of strong mature biofilms both on abiotic surfaces, and also within host organisms ${ }^{24,42}$. As mentioned previously, the conditions under which strains of E. coli express EcpA, leading to formation of ECP, varies greatly; the two examples of ECP-mediated adhesion mentioned were observed under very different growth conditions ${ }^{24,27,4,58}$.

It has also been reported for NMEC strains the EcpR acts not only as a positive regulator for the ecp operon, it also negatively regulates flagellar master operon $f l h D C^{41}$. In this role, EcpR is modulating the shift between planktonic and sessile lifestyles ${ }^{41}$. This is in agreement with ECP's role as an important colonization factor in E. coli, downregulation of flagella is a logical response to an increase in expression of structures important for adhesion ${ }^{41}$. Similarly positive regulation of another important E. coli colonization factor, curli, has been demonstrated to negatively regulate flagellar expression $^{41}$.

These observations collectively support important roles for ECP in adhesion to host cells, other bacterial cells, as well as abiotic surfaces ${ }^{4,24,27,41,42,58,64}$. The adhesion capabilities conferred by ECP on pathogenic E. coli serotypes to both host cells and other bacterial cells is a major advantage in infection, establishing a larger population helps to ensure survival and increase severity of the infection ${ }^{7,11,45,48}$. The consensus from researchers in this field is that regardless of serotype and pathogenicity, expression of this highly conserved structure allows for bacterial persistence both within and outside of a host organism, and increases the likelihood of survival and transmission ${ }^{4,24,27,42,58,64}$. 


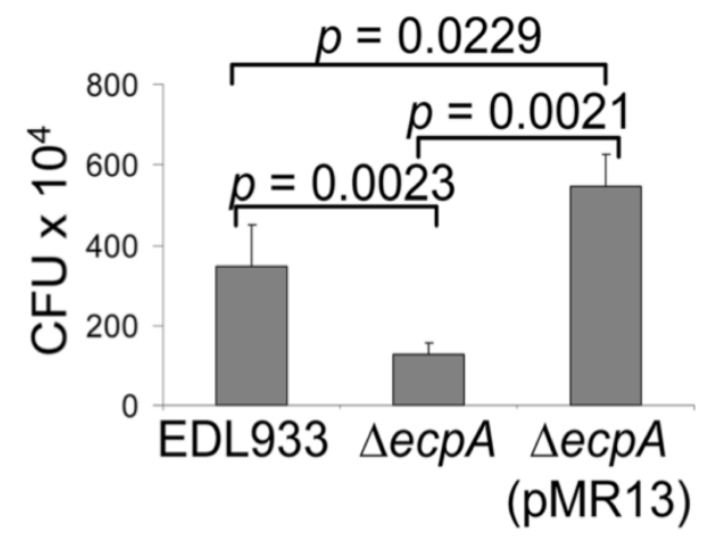

Figure 1.3: ECP is an important factor for EHEC adhesion to epithelial cells in vitro. An isogenic mutant strain lacking ecp $A$ shows a significant decrease in adhesion to HEp2 or HeLa cells when compared to the wild-type parental strain (EDL933). In the complimented isogenic mutant strain over-expressing ecp $A$, the adhesion phenotype is exaggerated (57).

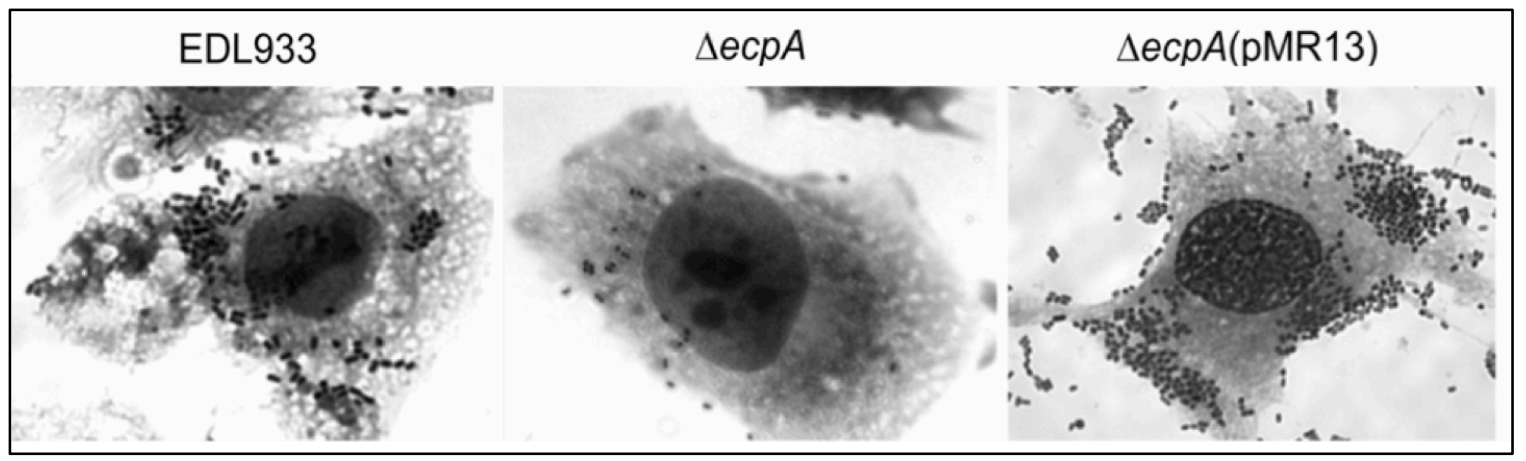

Figure 1.4: Adhesion of EHEC is decreased significantly in the absence of EcpA. These Giesma stained images demonstrate that an isogenic mutant lacking ecp $A$ is significantly less adherent to HEp-2 or HeLa cells in comparison to the parental strain (57). 


\subsection{Acid and Short-Chain Fatty Acid Stress}

The human gastrointestinal tract is a source of many bacterial environmental stresses. Among these are acute acid exposure in the stomach and exposure to short-chain fatty acids (SCFA) in the large intestine ${ }^{1,3,5,15,20,26,31,50,67}$. E. coli colonize columnar epithelial cells in the human large intestine and thus in order to reach their preferred environmental niche, all E. coli, both commensal and pathogenic, must survive both acid and SCFA exposure, both of which serve as sources of proton stress $3,11,19,20,45,50,63,71$.

The major damaging effect of acid or proton stresses is the alteration of the internal $\mathrm{pH}$ of the bacterial cell ${ }^{6,19,20,26}$. All bacteria have an optimum range of $\mathrm{pH}$ for activity of their intracellular components and processes, and to ensure a certain level of normal function they must maintain a cytoplasmic $\mathrm{pH}$ within that optimum range $\mathrm{e}^{6,19,20,26}$. Protons from $\mathrm{HCl}$ present in the stomach are able to diffuse across the bacterial cell membrane ${ }^{5,6,19}$. SCFAs, on the other hand, are weak acids and diffuse across the bacterial cell membrane without an immediate impact on $\mathrm{H}+$ concentration $^{60}$. However, once inside the cell's more alkaline cytoplasm, short-chain fatty acids dissociate into a lone hydrogen ion and an organic anion, effectively decreasing the internal $\mathrm{pH}^{5}$. E. coli have systems which counteract this effect, and they will be discussed later in more detail, but it is important to note that active re-alkalization of a bacterial cell requires energy in the form for adenosine triphosphate (ATP) and reliance on these systems could potentially deplete the cell's energy; a lack of available ATP for normal cell processes is in and of itself a negative effect ${ }^{54,60}$.

Beyond the acidification of the bacterial cytoplasm, the passive diffusion of shortchain fatty acids is damaging because it allows for the accumulation of organic anions within the cell, resulting in osmotic stress ${ }^{5,60}$. The build-up of these short-chain fatty acid derived organic anions, considered non-compatible solutes as they do effect cellular functions, leads to enlargement via increased turgor pressure within the cell as it works towards osmotic stability 5 . 


\subsection{Resistance to proton stress in $E$. coli}

E. coli have in place several acid resistance (AR) systems to combat proton stress. Which system the bacteria use to oppose proton stress is dependent on other environmental conditions $3,6,19,20,26,57,59,77$. The first system, acid resistance system 1 (AR 1) is known as oxidative or glucose repressed acid resistance ${ }^{3}$. This is a form of acid resistance that appears to originate not specifically from acid or proton stress, but occurs rather as a general protective stress response in stationary phase bacteria ${ }^{3,29}$. Interestingly, and as the name would suggest, upon addition of glucose to the environment, stationary cells lose this acid stress resistance ${ }^{3}$. AR 1 is linked to $\sigma^{\mathrm{S}}$, an alternate sigma factor that has been shown to be responsible for a major portion of the Salmonella acid tolerance system $^{3,29}$. The exact mechanisms by which AR 1 combats proton stress are unclear.

Acid resistance system 2 (AR 2) and 3 (AR 3) work via similar mechanisms, which can be described in combination, however it should be noted that they do differ in their levels of efficacy; AR 2 is E. coli's most effective acid stress response ${ }^{20}$. These systems work to combat proton stress by actively working to increase cytoplasmic $\mathrm{pH}$ levels ${ }^{20}$. Both AR2 and AR3 are comprised of an amino acid-specific decarboxylase and a cognate antiporter. AR 2 is a glutamate dependent system while AR 3 is dependent on $\operatorname{arginine} e^{20,77}$. This means that in order for the system to be active, the requisite amino acid must be present in the extracellular environment ${ }^{20}$. In brief, the decarboxylase removes the $\alpha$-carboxy group of its amino acid substrate, this process results in consumption of a proton from the cytoplasm ${ }^{20,77}$. The altered amino acid, glutamate/ $\gamma$-aminobutyric acid for AR 2 and agmatine for AR 3, are then transported out of the cell via the antiporter and exchanged for a new molecule of the original amino acid substrate (Figure 1.5) ${ }^{20}$. In addition to raising $\mathrm{pH}$ levels in the cytoplasm, the processing of amino acids to remove the $\alpha$-carboxy group and then releasing them back into the extracellular environment also help to increase extracellular $\mathrm{pH}$ levels ${ }^{3}$. 


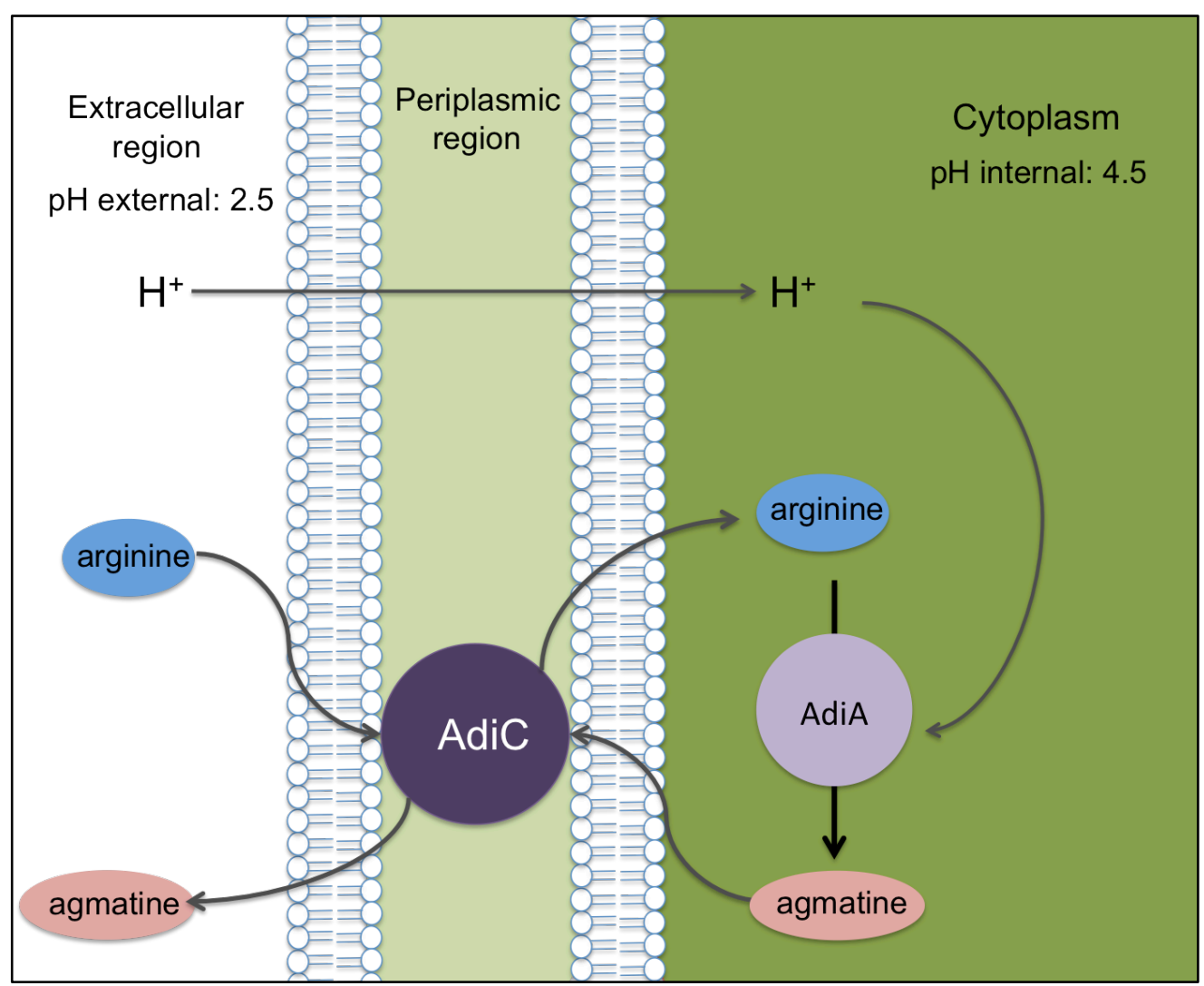

Figure 1.5: Schematic of Acid Resistance System 3 (AR3). In AR3, periplasmic antiporter AdiC internalizes extracellular arginine, and subsequently an arginine specific decarboxlase, AdiA, removes the $\alpha$-carboxy group from arginine. This process results in conversion of arginine to agmatine as well as the consumption of a cytoplasmic proton, leading to an increase in cytoplasmic $\mathrm{pH}$. Adapted from 20. 


\subsection{Impact of acid stress on ECP expression}

As was previously mentioned, during gastric passage bacteria such as EHEC are exposed to acutely acidic conditions in the human stomach. It has been reported that the $\mathrm{pH}$ of the human stomach can reach as levels high as $\mathrm{pH} 6$ and as low as $\mathrm{pH} 2^{20}$. DNA microarray analysis revealed a significant increase in expression of ecp $A$ in EHEC after a 1-hour acid adaptation at $\mathrm{pH} 5$, followed by a 30 -minute acute acid stress at $\mathrm{pH} 3^{31}$. A similar increase in ecpA expression was seen in EHEC that were not adapted to acid stress at $\mathrm{pH} 5$ (Figure 1.6) ${ }^{31}$. Both of these conditions are physiologically relevant and cover a broad range of potential stomach conditions to be potentially encountered by EHEC $^{20,31}$.

The microarray results were supported by subsequent adhesion assays that showed an increase in ECP-mediated adhesion. Acid adapted, acid stressed wild-type EHEC demonstrated an increase in levels of adhesion when compared to unstressed controls $^{27}$. When an isogenic mutant lacking ecpA was analyzed for levels of adhesion under the same acid stress and control conditions, both showed a significant decrease in comparison to the parental strain. Upon complementation of ecpA on a plasmid, the acidinduced adhesion phenotype was partially restored (Figure 1.7$)^{27}$.

\begin{tabular}{|lcc|}
\hline & \multicolumn{2}{c|}{ Relative-fold change } \\
\cline { 2 - 3 } Gene & $\mathrm{UA30}$ & AA30 \\
\hline $\begin{array}{l}\text { ecpA; major fimbrial subunit } \\
\text { of } E \text {. coli common pilus } \\
h n s ; \text { DNA-binding protein, } \\
\text { global translational } \\
\text { regulator }\end{array}$ & $5.6^{*}$ & $5.0^{*}$ \\
\hline
\end{tabular}

Figure 1.6: Microarray analysis of EHEC gene expression after acid stress. The gene encoding the major pilin subunit of ECP, ecp $A$, was upregulated at least 5-fold under both unadapted acid stress conditions and adapted acid stress conditions. (AA30: samples were adapted to acid stress at $\mathrm{pH} 5$ for 1 hour, followed by a 30 minute acute acid stress at $\mathrm{pH}$ 3.0. UA30 samples were not acid adapted, but were acute acid stressed at $\mathrm{pH} 3.0$ for 30 minutes) (31). 


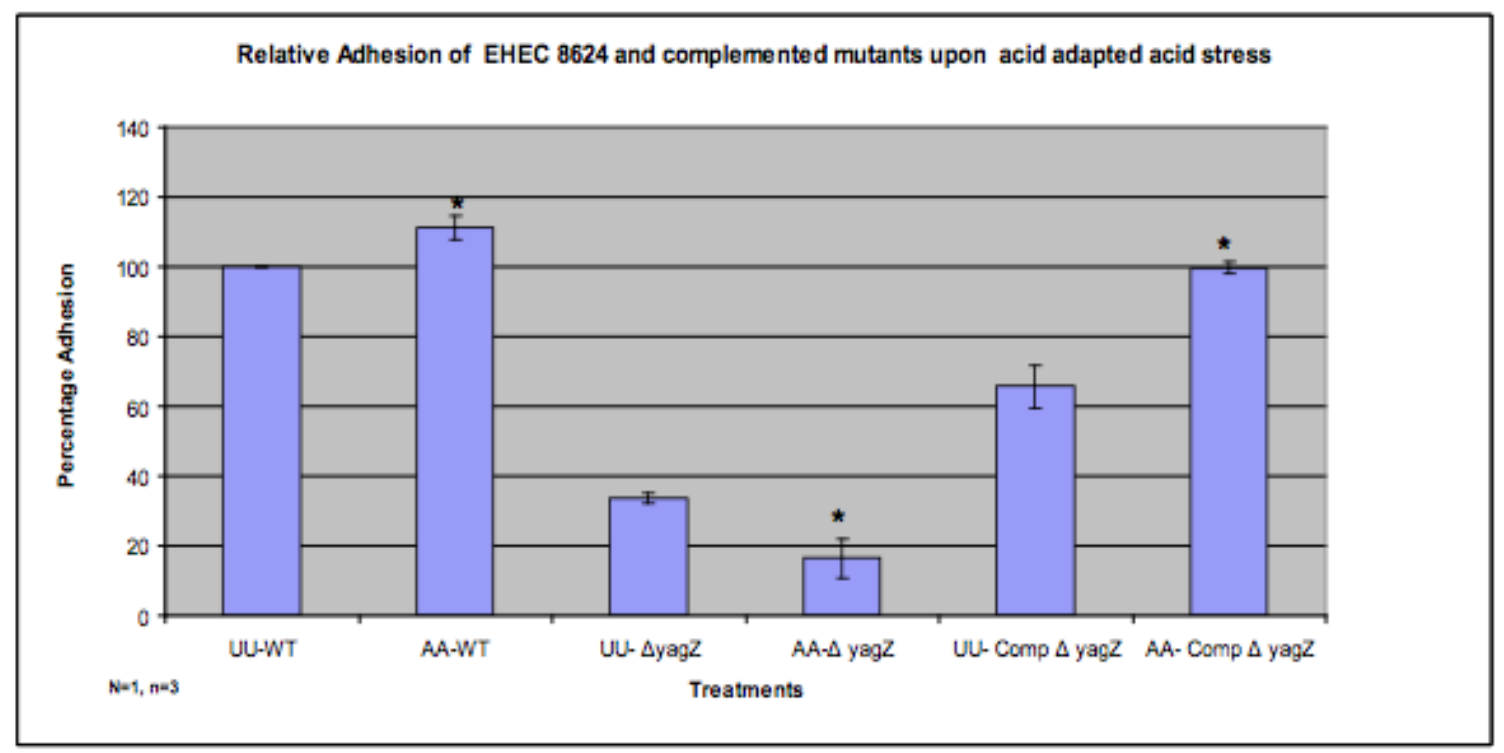

Figure 1.7: Exposure to acid stress increases EHEC ECP-mediated adhesion to epithelial cells. In wild-type EHEC, there is a significant increase in adhesion in acid stressed samples compared to unstressed control samples. That phenotype is lost in an isogenic mutant lacking ecpA (yagZ), but is restored upon complementation. (UU-WT: unadapted, unstressed wild-type EHEC, AA-WT: acid adapted, acid stressed 30 mins. wild-type, UU- $\operatorname{yag} Z$ : unadapted, unstressed isogenic ecpA mutant, AA-WT: acid adapted, acid stressed 30 mins. isogenic ecpA mutant, UU-Comp $\Delta y a g Z$ : unadapted, unstressed complimented isogenic ecpA mutant, AA-Comp $\triangle y a g Z$ : acid adapted, acid stressed 30 mins. complimented isogenic ecp $A$ mutant) (27)

\subsection{Impact of SCFA stress on ECP expression}

Enteric bacteria produce SCFAs as a byproduct of fermentation of soluble fiber ${ }^{1,15,25,60,80}$. The localization of SCFAs in the colon is due to the increasingly anaerobic conditions present in that portion of the gastrointestinal tract ${ }^{60}$. Starting in the distal ileum, SCFAs are found at a total concentration of 20-40 mM, in the proximal colon the concentration increases to $70-140 \mathrm{mM}$, and then decreases to $20-70 \mathrm{mM}$ in the distal colon; human feces have been reported to contain $172 \mathrm{mM}^{54,60,80}$. The three main SCFAs present in the human colon are, in descending order, acetate, propionate, and butyrate $^{54,60,80}$. The these compounds have been reported to be present in a ratio of $60: 25: 15$ of acetate:propionate:butyrate ${ }^{80}$. SCFA stress was experimentally defined as static exposure of bacteria to a $30 \mathrm{mM}, 90 \mathrm{mM}$, or $172 \mathrm{mM}$ mix of acetate, propionate, and butyrate for 2 hours in a $5 \% \mathrm{CO}_{2}$ atmosphere ${ }^{27,67}$. Adhesion of $90 \mathrm{mM}$ SCFA stressed wild-type EHEC to human epithelial cells was significantly higher than the unstressed 
control samples ${ }^{27,67}$. As was also seen with the acid stress adhesion assays, the isogenic ecpA mutant strain showed a significant decrease in adhesion in comparison to the parental $\operatorname{strain}^{27}$. Again the phenotype was partially restored upon plasmid complementation of ecpA in the isogenic mutant strain (Figure 1.8) ${ }^{27}$.

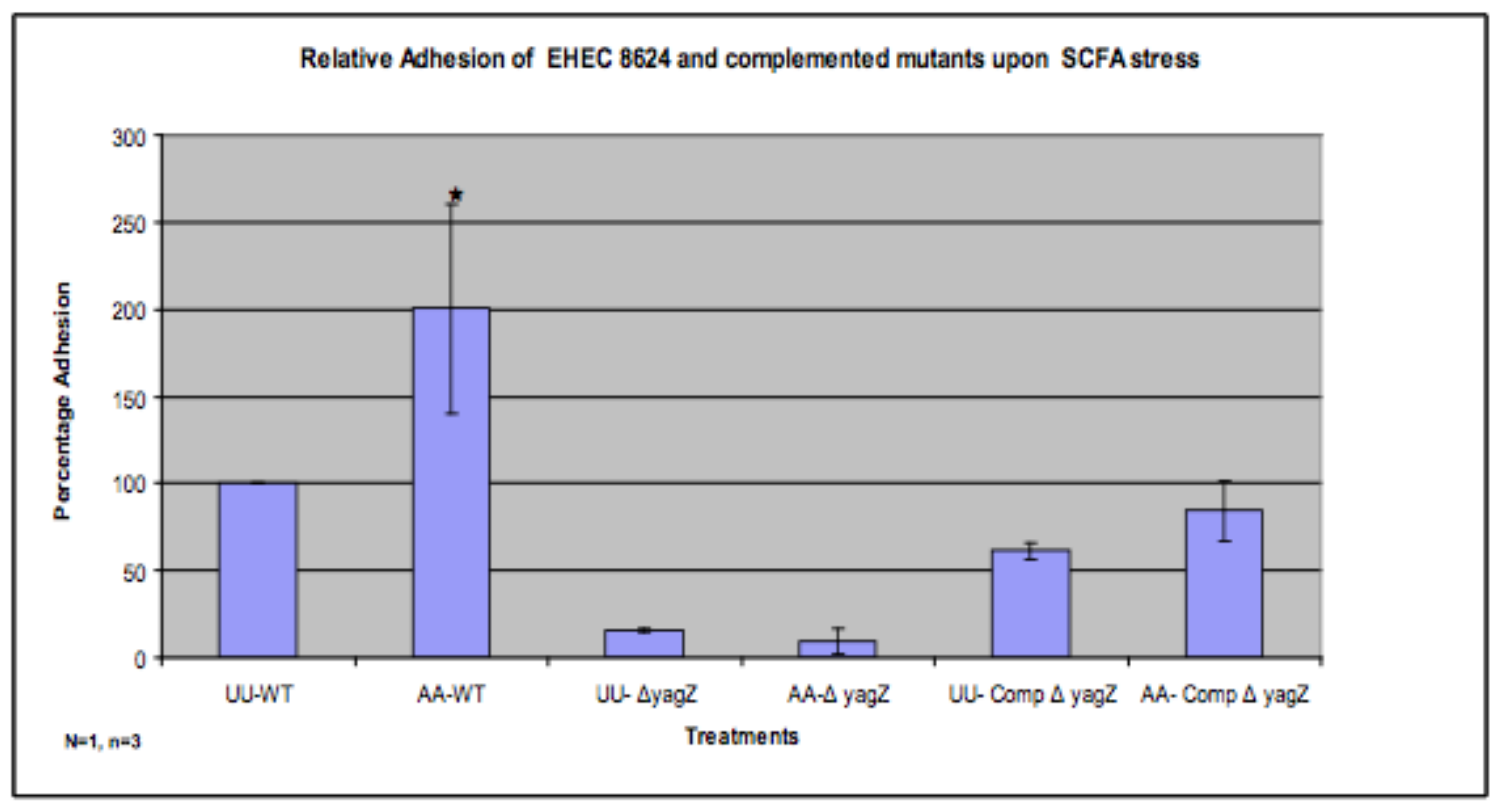

Figure 1.8: Exposure to 90mM SCFA stress increases EHEC ECP-mediated adhesion to epithelial cells. In wild-type EHEC, there is a significant increase in adhesion in SCFA stressed samples compared to unstressed control samples. That phenotype is lost in an isogenic mutant lacking ecpA (yagZ), but is restored upon complementation. (UU-WT: unstressed wild-type EHEC, AA-WT: 90mM SCFA mix stressed wild-type, UU-DyagZ: unstressed isogenic ecpA mutant, AA-WT: 90mM SCFA mix stressed isogenic ecpA mutant, UU-Comp $\triangle y a g Z$ : unstressed complimented isogenic eсpA mutant, AA-Comp $\triangle y a g Z$ : $90 \mathrm{mM}$ SCFA mix stressed complimented isogenic ecpA mutant) (27) 


\subsection{Transcriptional regulation of the ecp operon}

Transcription of the genes of the ECP fimbrial operon (ecp operon) has been shown to be regulated by three proteins: the histone-like nucleoid structuring protein $(\mathrm{H}-$ NS), integration host factor (IHF), and the previously mentioned intra-operon regulator $\mathrm{EcpR}^{43,47}$.

H-NS is a DNA-binding protein that has been implicated in regulating expression of upwards of $60 \mathrm{E}$. coli proteins, many of them are environmentally regulated or involved in stress tolerance. H-NS is most often known to negatively regulate target genes $^{2,14,18,36,47,53,62,69,73,74,76,79,81}$. Results also indicate a role of H-NS in repressing the transcription of the ecp operon ${ }^{43,47}$. Additionally, the previously mentioned DNA microarray showed a slight decrease in mRNA levels for hns upon AA30 acid stress that correlates with an increase in transcription of ecp $A^{31}$.

IHF is also a DNA binding protein that is not specifically a regulator of the ecp operon ${ }^{65}$. IHF does not act directly as a positive regulator of the ecp operon; rather it acts

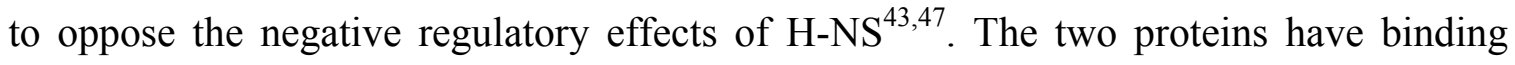
sites within a small stretch of DNA in the promoter region of the ecp operon, and because both IHF and H-NS act through winding or bending of DNA to allow or prevent transcription of the target gene, their oppositional roles in close proximity are logical as a method to control transcription of the ecp operon ${ }^{43,47,36,65,69}$.

The last member of the ecp operon transcriptional regulatory story is EcpR. EcpR is the first gene in the ecp operon, and like other first genes in an operon that encodes a chaperon/usher assembled fimbrial structure, EcpR acts as an intra-operon positive regulator, enhancing expression of the other genes in the operon through binding of promoter regions upstream of the ecp operon ${ }^{9,33,43,47}$. 


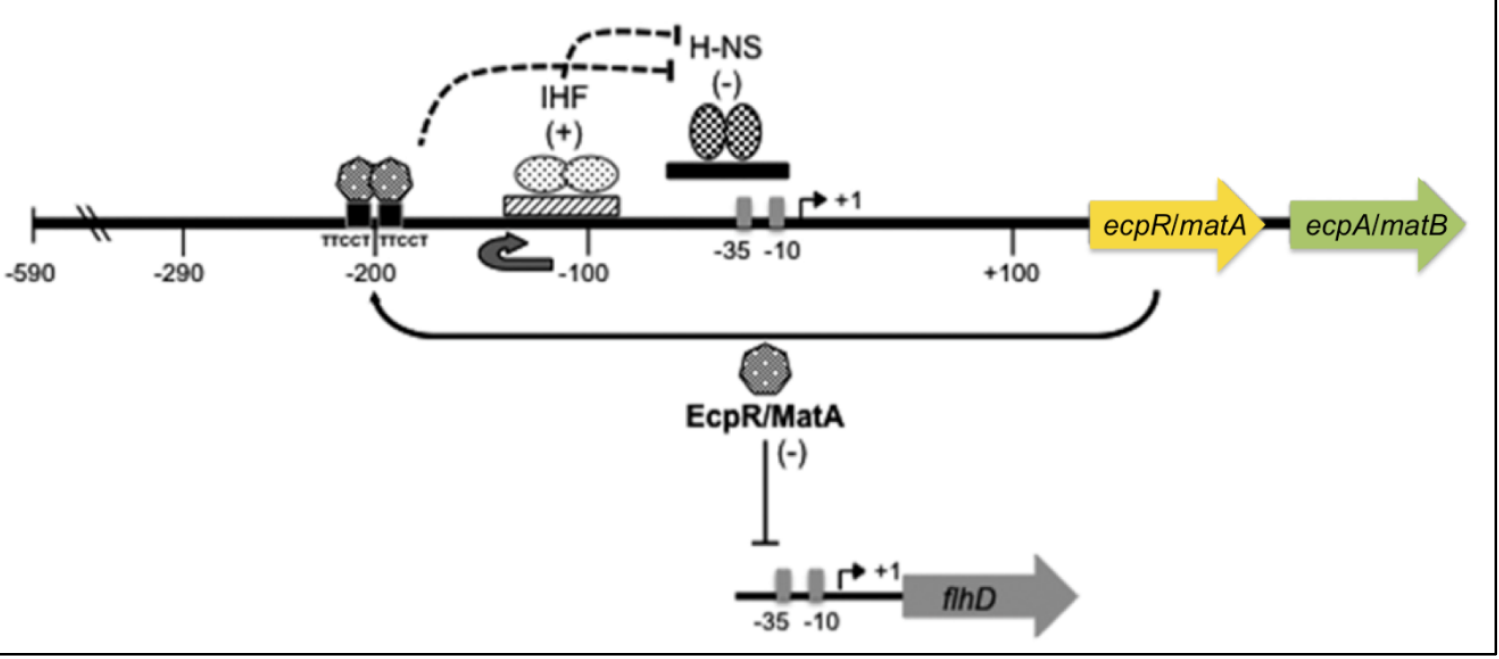

Figure 1.9: Schematic of ecp operon transcriptional regulation. Global regulator HNS has been shown to negatively regulate this operon, while the operon specific regulator EcpR is a positive regulator. The negative regulation imposed on the operon is opposed in the presence of IHF, allowing for expression. Image modified from 46.

\subsection{Translational regulation of the ecp operon}

Once есрA has been transcribed into mRNA, there is another regulatory system that can effect the expression of ecpA on a protein level. A translational regulatory system for the ecp $A$ has been pieced together from previously known components of other regulatory mechanisms present in E. coli. The two-component transduction system BarA/UvrY has been shown to be activated, through stimulation of BarA and subsequent activation of DNA-binding protein UvrY, by exposure to aliphatic carboxylic acids such as methyl acetate $(6 \mathrm{mM})$ and other SCFAs ${ }^{12,55}$. Activation of BarA/UvrY leads to an increase in expression of two small non-coding RNAs, CsrB and $\mathrm{CsrC}^{12,35,51,68,70,72}$.

This is the point at which the SCFA regulatory response in EHEC intersects with a global regulatory system suspected to regulate ecp $A$ translation. CsrA is an RNA binding protein that acts to regulate translation of target transcripts by sequestering and degrading mRNA ${ }^{34,35,68,70}$. CsrB and CsrC inhibit CsrA binding of target transcripts because the small non-coding RNAs will occupy RNA binding sites on CsrA, blocking CsrA from binding additional RNA ${ }^{34,35,68,70}$. The ecp $A$ transcript has been reported to be a target for CsrA sequestration and/or degradation (J. Puente, personal communication, 
May 26, 2011). This leads to the hypothesis that upon an increase in $\mathrm{CsrB} / \mathrm{CsrC}$ expression due to SCFA exposure, CsrA-mediated repression of ecpA translation would be decreased, and protein levels of EcpA would increase.

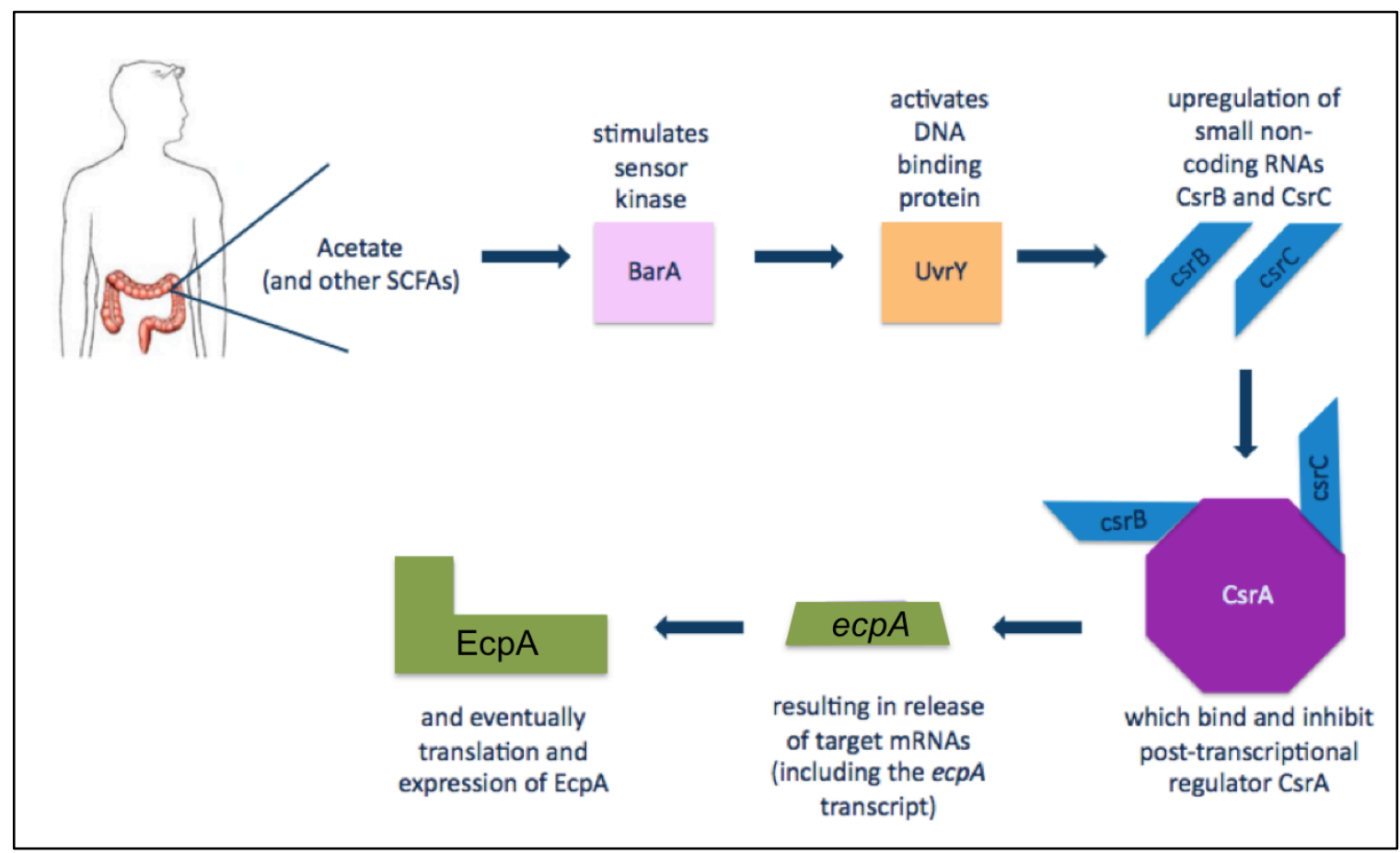

Figure 1.10: Schematic of hypothetical ecp operon translational regulation. Sensor kinase BarA is stimulated by exposure to the carboxylate group of aliphatic carboxylic acids, including SCFAs, and in turn activates its response regulator UvrY. Activation of UvrY increases expression of small non-coding RNAs CsrB and CsrC. $\mathrm{CsrB} / \mathrm{C}$ are known to inhibit a global post-transcriptional regulator, CsrA. CsrA acts by sequestering the transcripts of target genes, potentially included is the mRNA for ecp $A$, and preventing them from being translated. Upregulation of $\mathrm{CsrB} / \mathrm{C}$ via activation of BarA/UvrY after stimulation from SCFA exposure could lead to an increase in EcpA. 


\subsection{Rationale}

The E. coli common pilus (ECP) has been shown to contribute to adhesion of both pathogenic and non-pathogenic E. coli to epithelial cells. Previous work has shown that both acid and SCFA stress enhance ECP-mediated adhesion, and that acid stress increases expression of the ecpA transcript for EHEC O157:H7. Understanding how these GI stresses modulate the transcriptional and translational expression of EcpA, and ultimately the E. coli common pilus, can contribute to our understanding of how EHEC is able to gain an adhesive advantage after exposure to acid or SCFA stress.

\subsection{Hypothesis}

Microarray analysis has shown an increase in expression of ecp $A$ in acid stressed EHEC O157:H7, and adhesion assays have shown an increase in adhesion for EHEC O157:H7 upon acid and SCFA stress which is lost in mutant strains lacking ecpA, but partially restored in the ecpA complemented mutant. This increase in ecpA expression is modulated by environmental stresses by global transcriptional, as well as translational, regulators.

\subsection{Objectives:}

I. Determine changes in expression of EcpA in wild-type EHEC O157:H7 after exposure to GI stresses. EHEC will be exposed to acid or SCFA stress and levels of EcpA will be analyzed via Western blotting with $\alpha$-EcpA antibodies. Promoter activity for the ecp operon will be assessed with beta-galactosidase activity assays.

\section{Construction of hns, uvrY, or ecpA deficient mutants of EHEC 0157:H7.} Mutants deficient of each gene will be constructed via $\lambda$ red recombinase mediated homologous recombination.

III. Characterization of EHEC O157:H7 hns and $u v r Y$ mutants. Regulatory mutants will be exposed to acid or SCFA stress and levels of EcpA will be assessed via Western blotting with $\alpha$-EcpA antibodies. Promoter activity for the ecp operon will be assessed with beta-galactosidase activity assays in EDL933 hns::Kan ${ }^{\mathrm{R}}$. 


\section{Materials and Methods}

\subsection{Bacterial cultivation}

Bacterial strains, detailed in table 2.1 , were maintained at $-80^{\circ} \mathrm{C}$ as glycerol stocks $\left(15 \%\right.$ glycerol, v/v) and at $4^{\circ} \mathrm{C}$ as bacterial working stocks on Luria broth (LB) agar plates $(1 \%$ tryptone $\mathrm{w} / \mathrm{v}, 0.5 \%$ yeast extract $\mathrm{w} / \mathrm{v}, 1 \%$ sodium chloride $\mathrm{w} / \mathrm{v}, 1.5 \%$ agar w/v) with antibiotics added as needed for mutant or plasmid carrying strains. Standard concentrations of antibiotics are shown in table 2.3. Bacterial working stocks were typically incubated overnight at $37^{\circ} \mathrm{C}$, however strains carrying the temperature sensitive plasmids pKD46 or pCP20 were incubated at $30^{\circ} \mathrm{C}$. Bacterial working stocks were subcultured every two weeks. Overnight liquid cultures were inoculated with a single colony from the working stock, with antibiotics added to standard concentrations when needed, and grown overnight at the appropriate temperature for the strain in a shaking incubator $(200 \mathrm{rpm})$ for an average of 16 hours.

\section{Table 2.1: Plasmids and constructs used in this study}

\begin{tabular}{|l|l|c|}
\hline Name & Description & Source \\
\hline pKD4 & $\begin{array}{l}\text { Plasmid pKD4, source of kanamycin resistance } \\
\text { cassette, with flanking FRT-sites, used to create } \\
\text { isogenic mutants; Amp }{ }^{\mathrm{R}}, \mathrm{Kan}^{\mathrm{R}} / \mathrm{Neo}^{\mathrm{R}}\end{array}$ & 16 \\
\hline $\mathrm{pKD} 46$ & $\begin{array}{l}\text { Plasmid pKD46, provides } \lambda \text { red recombinase } \\
\text { system for homologous recombination; Amp }\end{array}$ & 16 \\
\hline pMC1403 & $\begin{array}{l}\text { Plasmid used for cloning promoters such that } \\
\text { they promote expression of beta-galactosidase } \\
\text { and allow for analysis of promoter activity levels; } \\
\text { Amp }{ }^{\mathrm{R}}\end{array}$ & 10 \\
\hline pMC1403-PecpR & $\begin{array}{l}\text { Promoter region of ecpR into XmaI/BamHI sites } \\
\text { of the multiple cloning site of pMC1403; Amp }\end{array}$ & This \\
study \\
\hline pMC1403-PacrA & $\begin{array}{l}\text { Promoter region of } \text { acrA into EcoRI/BamHI sites } \\
\text { of the multiple cloning site of pMC1403; Amp }{ }^{\mathrm{R}}\end{array}$ & 38 \\
\hline
\end{tabular}


Table 2.2: Bacterial strains used in this study

\begin{tabular}{|c|c|c|}
\hline Strain & Characteristics & Source \\
\hline EDL933 & Wild type E. coli $\mathrm{O} 157: \mathrm{H} 7$ & 44 \\
\hline EDL933 PecpR & $\begin{array}{l}\text { Wild type E. coli } \mathrm{O} 157: \mathrm{H} 7 \text { transformed } \\
\text { with pMC1403+PecpR; Amp }\end{array}$ & This study \\
\hline EDL933 pMC1403 & $\begin{array}{l}\text { Wild type E. coli } \mathrm{O} 157: \mathrm{H} 7 \text { transformed } \\
\text { with pMC1403; Amp }{ }^{\mathrm{R}}\end{array}$ & This study \\
\hline EDL933 pKD46 & $\begin{array}{l}\text { Wild type } E . \text { coli } \mathrm{O} 157: \mathrm{H} 7 \text { transformed } \\
\text { with pKD46; } \mathrm{Amp}^{\mathrm{R}}\end{array}$ & 82 \\
\hline EDL933 ecp $:: \operatorname{Kan}^{\mathrm{R}}$ & $\begin{array}{l}\text { EDL933 with } \operatorname{Kan}^{\mathrm{R}} \quad \text { chromosomal } \\
\text { disruption of ecpA; } \operatorname{Kan}^{\mathrm{R}}\end{array}$ & 57 \\
\hline EDL933 hns::Kan ${ }^{\mathrm{R}}$ & $\begin{array}{l}\text { EDL933 with } \operatorname{Kan}^{\mathrm{R}} \quad \text { chromosomal } \\
\text { disruption of } h n s ; \operatorname{Kan}^{\mathrm{R}}\end{array}$ & This study \\
\hline EDL933 hns::Kan ${ }^{\mathrm{R}} \mathrm{PecpR}$ & $\begin{array}{l}\text { EDL933 hns::Kan }{ }^{\mathrm{R}} \text { transformed with } \\
\text { pMC1403+PecpR; } \mathrm{Amp}^{\mathrm{R}}\end{array}$ & This study \\
\hline EDL933 hns::Kan ${ }^{\mathrm{R}}$ pMC1403 & $\begin{array}{l}\text { EDL933 hns::Kan }{ }^{\mathrm{R}} \text { transformed with } \\
\text { pMC1403, Amp }\end{array}$ & This study \\
\hline EDL933 uvrY::Kan ${ }^{\mathrm{R}}$ & $\begin{array}{l}\text { EDL933 with } \operatorname{Kan}^{\mathrm{R}} \quad \text { chromosomal } \\
\text { disruption of } u v r Y ; \operatorname{Kan}^{\mathrm{R}}\end{array}$ & This study \\
\hline 86-24 PacrA & $\begin{array}{l}\text { Wild-type E. coli } \mathrm{O} 157: \mathrm{H} 7 \text { transformed } \\
\text { with pMC1403+PacrA; } \mathrm{Amp}^{\mathrm{R}}\end{array}$ & 38 \\
\hline
\end{tabular}

Table 2.3: Standard antibiotic concentrations used in this study

\begin{tabular}{|l|l|}
\hline Antibiotic & Working concentration \\
\hline Ampicillin & $100 \mu \mathrm{g} / \mathrm{mL}$ \\
\hline Kanamycin & $50 \mu \mathrm{g} / \mathrm{mL}$ \\
\hline
\end{tabular}




\subsection{Creation of isogenic mutants}

EDL933 isogenic mutants were created for ecpA, hns, and $u v r Y$ through $\lambda$-red recombinase-mediated homologous recombination.

\subsubsection{Plasmid purification}

Plasmids used in this study, listed in Table 2.1, were all isolated with spin column minipreps (Qiagen). A $5 \mathrm{~mL}$ overnight culture of the parental strain of interest was incubated at the appropriate temperature for the plasmid to be purified, overnight, with shaking. The following morning the miniprep was completed, as per the manufacturer's directions. This included pelleting and subsequent lysis of bacteria, separation of cellular debris from DNA, binding of plasmid DNA to a silica resin, washing samples with ethanol, and finally elution of plasmid DNA in Tris-buffer. Purified plasmid DNA was stored at $-20^{\circ} \mathrm{C}$.

\subsubsection{Primer design and PCR amplification of kanamycin resistance cassette}

Primers were designed, using molecular biology computer programs SerialCloner and ApE, to amplify the kanamycin resistance cassette from $\mathrm{pKD} 4$, with $\sim 50 \mathrm{bp}$ extensions carrying homology to regions either upstream or downstream of the target gene. The built in regions of homology will allow for the subsequent PCR product to integrate into the chromosome, essentially inserting the kanamycin resistance cassette in place of the target gene. A BLAST search was performed to confirm that both the upstream and downstream homology regions used in each primer set were unique within the genome of EDL933. This was done to ensure that homologous recombination would occur only the region of the chromosome surrounding the target gene. 


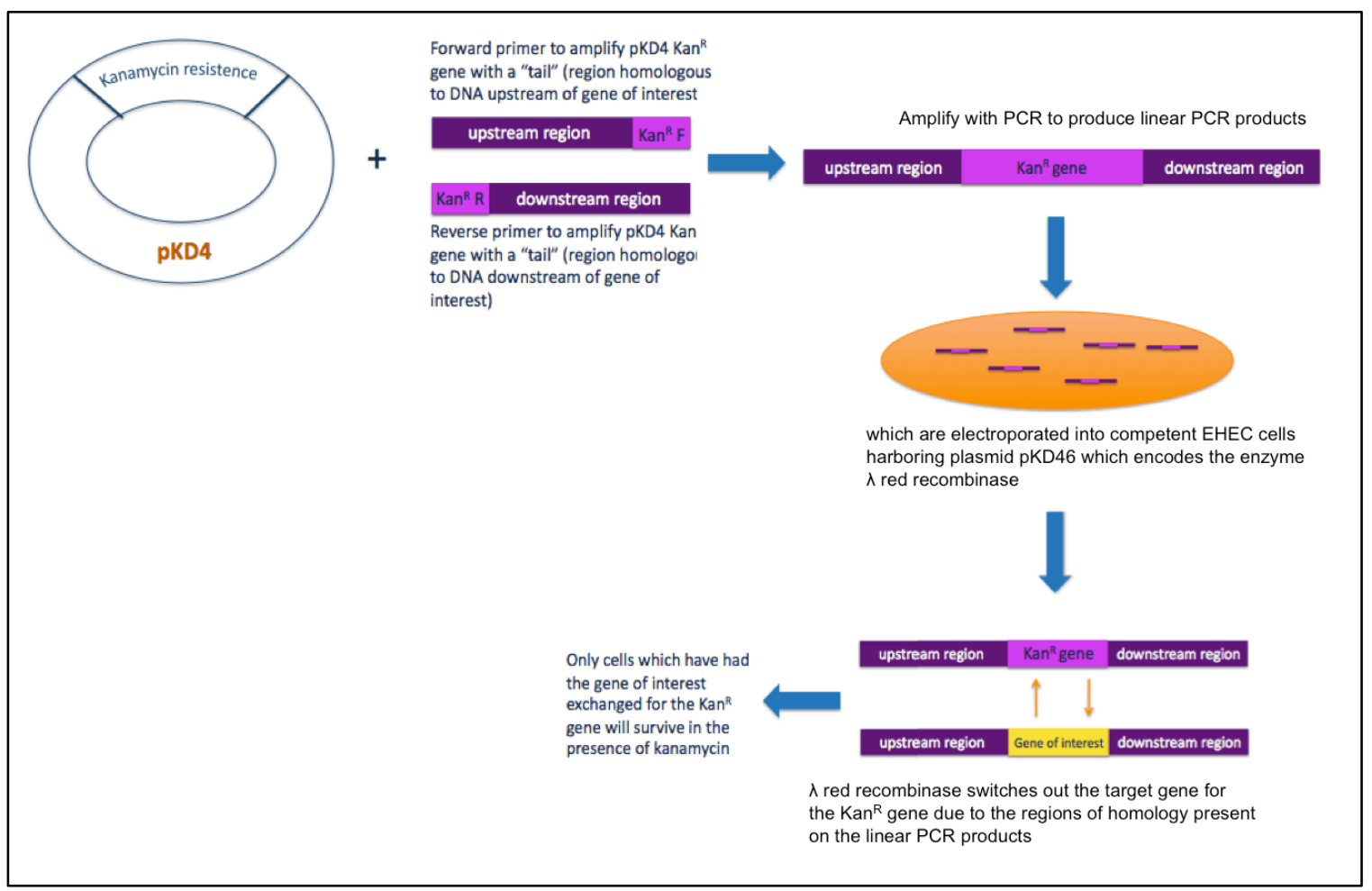

Figure 2.1: Overview of $\lambda$ red recombinase-mediated homologous recombination.

The kanamycin resistence $\left(\mathrm{Kan}^{\mathrm{R}}\right)$ gene of pKD4 is amplified with PCR using primers designed to integrate regions, upstream and downstream of the $\mathrm{Kan}^{\mathrm{R}}$ gene, homologous to upstream and downstream regions of the target gene. These linear PCR products are used to transform EHEC carrying pKD46, encoding $\lambda$ red recombinase, which mediates the integration of the $\mathrm{Kan}^{\mathrm{R}}$ gene into the bacterial chromosome, eliminating the target gene.

All primer sequences are listed in table 2.4. These primers were used in a $200 \mathrm{uL}$ PCR reaction as follows; 20uL 5X Phusion HF buffer, $1.6 \mathrm{uL} 10 \mathrm{mM}$ dNTP mix, 4uL $10 \mathrm{uM}$ forward primer, $4 \mathrm{uL} 10 \mathrm{uM}$ reverse primer, $4 \mathrm{uL}$ pKD4 miniprep, $49.6 \mathrm{uL}$ sterile PCR grade water, $0.8 \mathrm{uL}$ Phusion DNA polymerase. The reaction mixture was divided into four 50uL aliquots in flat-cap PCR tubes. All PCR reactions were run on a BioRad thermocycler. The cycling conditions were as follows; 30 second initial denaturation at $98^{\circ} \mathrm{C}, 35$ cycles of a 10 second denaturation at $98^{\circ} \mathrm{C}$ then a 30 second annealing at primer specific temperatures (see table 2.4 for details) and then a 30 second extension at $72^{\circ} \mathrm{C}$, a 10 minute final extension at $72^{\circ} \mathrm{C}$, and a $4^{\circ} \mathrm{C}$ hold until samples were collected. Results were visualized on a $1 \%$ agarose gel. Positive results were then subjected to gel extraction purification and sample concentration (Qiagen). 


\subsubsection{Preparation of electrocompetent EHEC}

In order to disrupt the target gene through integration of a kanamycin resistance cassette with $\lambda$-red recombinase mediated homologous recombination, linear PCR products generated in section 2.2.2 must be electroporated into EDL933 already carrying the $\lambda$-red recombinase encoding plasmid pKD46. An overnight culture of EDL933 (pKD46) was grown overnight at $30^{\circ} \mathrm{C}$ in $5 \mathrm{~mL}$ LB broth with $50 \mathrm{ug} / \mathrm{mL}$ ampicillin (Amp). The following morning the overnight culture was diluted 1:50 in 50ug/mL Amp, $100 \mathrm{mM}$ L-arabinose $\mathrm{LB}$ broth and incubated at $30^{\circ} \mathrm{C}$ with shaking until the $\mathrm{OD}_{600}$ reaches $\sim 0.4$. The subculture was placed in pre-chilled $50 \mathrm{~mL}$ centrifuge tubes, kept on ice for 10 minutes, and then the bacteria pelleted at $2061 \mathrm{x} \mathrm{g}(3100 \mathrm{rpm})$ at $4^{\circ} \mathrm{C}$ for 10 minutes. The supernatant was removed, and the pellet resuspended in 1/10 volume of the original subculture volume of ice-cold sterile distilled water. Cells were kept on ice for 10 minutes and re-spun as described previously. This step was repeated a second time. The bacterial pellet was then resuspended in $1 / 20$ volume of the original subculture volume of ice-cold sterile $10 \%$ glycerol water and re-spun as previously described. This step was also repeated a second time. After the second glycerol wash, the pellet was resuspended in 1/100 volume of the original subculture volume, divided into $100 \mathrm{uL}$ aliquots in pre-chilled microcentrifuge tubes, and kept on ice until needed for electroporation.

\subsubsection{Electroporation}

Between 1 and $5 \mathrm{uL}$ of concentrated and purified PCR reaction was used to transform 100uL of electrocompetent EDL933 (pKD46) in $1 \mathrm{~mm}$ gap electroporation cuvettes using an electroporation unit (BioRad) with the following settings; $2.5 \mathrm{kV}, 25 \mu \mathrm{F}$, $200 \Omega$. Electroporated bacteria were immediately added to $900 \mathrm{uL}$ of $30^{\circ} \mathrm{C}$ Super Optimum Broth with Catabolite repression (SOC) media $(0.5 \% \mathrm{w} / \mathrm{v}$ yeast extract, $2 \% \mathrm{w} / \mathrm{v}$ tryptone, $10 \mathrm{mM} \mathrm{NaCl}, 2.5 \mathrm{mM} \mathrm{KCl}, 10 \mathrm{mM} \mathrm{MgCl} 2,10 \mathrm{mM} \mathrm{MgSO}_{4}, 20 \mathrm{mM}$ glucose) and allowed to recover for 3 hours at $30^{\circ} \mathrm{C}$ with shaking. After recovery, bacteria were spread onto LB-kanamycin plates and incubated overnight at $37^{\circ} \mathrm{C}$. 


\subsubsection{Colony PCR screening}

Following transformation, all colonies obtained were re-streaked onto new LBkanamycin plates and screened, through colony PCR using primers designed to amplify a region outside of the target gene, for successful gene disruption and the integration of a kanamycin resistance cassette. The $25 \mathrm{uL}$ colony PCR reaction mix was as follows: $2.5 \mathrm{uL}$ Taq buffer with $\mathrm{Mg}^{2+}$ (Genscript), 0.5uL 10mM dNTP mix (Genscript), 0.5uL 50uM forward primer (ACGT), 0.5uL 50uM reverse primer (ACGT), 20uL sterile PCR grade water (Genscript), 0.25uL Taq DNA polymerase (Genscript). 25uL aliquots were each inoculated with a single candidate colony. The cycling conditions were as follows; 10 minute initial denaturation at $94^{\circ} \mathrm{C}, 35$ cycles of a 30 second denaturation at $94^{\circ} \mathrm{C}$ then a 45 second annealing at primer specific temperatures, see table 2.3 for details and then a 60 second extension at $72^{\circ} \mathrm{C}$, a 7 minute final extension at $72^{\circ} \mathrm{C}$, and a $4^{\circ} \mathrm{C}$ hold until samples were collected. Results were visualized on a $1 \%$ agarose gel. Positive results were confirmed with sequence analysis. 
Table 2.4: Primers used in this study

\begin{tabular}{|c|c|c|c|c|}
\hline Primer name & Sequence (5'-3') & $\begin{array}{l}\text { A. } \\
\text { Temp. }\end{array}$ & Product/Target & Source \\
\hline ecp $A /$ kanR F & $\begin{array}{l}\text { GTTCTGGCAATAGCTCTGGTAACG } \\
\text { GTGTTTACCGGGTGTAGGCTGGAG } \\
\text { CTGCTTCC }\end{array}$ & \multirow{2}{*}{$61^{\circ} \mathrm{C}$} & \multirow{2}{*}{$\begin{array}{l}\text { Kanamycin resistance } \\
\text { cassette from pKD4 } \\
\text { with ecp } A \text { upstream } \\
\text { and downstream } \\
\text { homology regions }\end{array}$} & \multirow[b]{2}{*}{57} \\
\hline ecpA/kanR R & $\begin{array}{l}\text { TTAACTGGTCCAGGTCGCGTCGAA } \\
\text { CTGTACGCTAACCATATGAATATCC } \\
\text { TCCTTAG }\end{array}$ & & & \\
\hline ecp $A$ check $\mathrm{F}$ & AACAGCAATATTAGGGGCGTG & \multirow{3}{*}{$51^{\circ} \mathrm{C}$} & \multirow{3}{*}{$\begin{array}{l}\text { Region of EDL } 933 \\
\text { chromosome outside } \\
\text { of ecpA }\end{array}$} & \multirow{3}{*}{57} \\
\hline & & & & \\
\hline ecp $A$ check $\mathrm{R}$ & GGATAACAGCAGAGCGAGAAG & & & \\
\hline hns/kanR F & $\begin{array}{l}\text { TCTATTATTACCTCAACAAACCACC } \\
\text { CCAATATAAGTTTGAGATTACTAC } \\
\text { AGTGTAGGCTGGAGCTGCTTC }\end{array}$ & \multirow{2}{*}{$50^{\circ} \mathrm{C}$} & \multirow{2}{*}{$\begin{array}{l}\text { Kanamycin resistance } \\
\text { cassette from pKD4 } \\
\text { with hns upstream } \\
\text { and downstream } \\
\text { homology regions }\end{array}$} & \multirow{2}{*}{$\begin{array}{l}\text { This } \\
\text { study }\end{array}$} \\
\hline hns/kanR R & $\begin{array}{l}\text { AAAAAATCCCGCCGATGGCGGGAT } \\
\text { TTTAAGCAAGTGCAATCTACAAAA } \\
\text { GAATGGGAATTAGCCATGGTCC }\end{array}$ & & & \\
\hline hns check F & TCCACGAAACGGCGTTGAGCAA & \multirow{3}{*}{$56^{\circ} \mathrm{C}$} & \multirow{3}{*}{$\begin{array}{l}\text { Region of EDL } 933 \\
\text { chromosome outside } \\
\text { of } h n s\end{array}$} & \multirow{3}{*}{$\begin{array}{l}\text { This } \\
\text { study }\end{array}$} \\
\hline & & & & \\
\hline hns check R & CCTTACATTCCTGGCTATTGCACA & & & \\
\hline$u v r Y / \operatorname{kanR} \mathrm{F}$ & $\begin{array}{l}\text { TAACTATCAGTAGCGTTATCCCTAT } \\
\text { TTCTGGAGATATTCCTGTGTAGGCT } \\
\text { GGAGCTGCTTC }\end{array}$ & \multirow{2}{*}{$50^{\circ} \mathrm{C}$} & \multirow{2}{*}{$\begin{array}{l}\text { Kanamycin resistance } \\
\text { cassette from pKD4 } \\
\text { with } u v r Y \text { upstream } \\
\text { and downstream } \\
\text { homology regions }\end{array}$} & \multirow{2}{*}{$\begin{array}{l}\text { This } \\
\text { study }\end{array}$} \\
\hline$u v r Y / \operatorname{kanR} \mathrm{R}$ & $\begin{array}{l}\text { TTACGGTTTTTAAAAACGCTTTTGC } \\
\text { GTCAAACTGATCACATGGGAATTA } \\
\text { GCCATGGTCC }\end{array}$ & & & \\
\hline$u v r Y$ check $\mathrm{F}$ & CCGACATAGATAACCGTACCA & \multirow{3}{*}{$50^{\circ} \mathrm{C}$} & \multirow{3}{*}{$\begin{array}{l}\text { Region of EDL } 933 \\
\text { chromosome outside } \\
\text { of } u v r Y\end{array}$} & \multirow{3}{*}{$\begin{array}{l}\text { This } \\
\text { study }\end{array}$} \\
\hline & & & & \\
\hline$u v r Y$ check $\mathrm{R}$ & CGTGACCATAACTGTGGACA & & & \\
\hline $\mathrm{PecpR}$ XmaI F & $\begin{array}{l}\text { GAGAGACCCGGGTCCATTACACAA } \\
\text { CACATTAAGAC }\end{array}$ & \multirow[b]{2}{*}{$69^{\circ} \mathrm{C}$} & \multirow{2}{*}{$\begin{array}{l}\text { EDL933 ecpR } \\
\text { promoter region with } \\
5 \text { 'XmaI recognition } \\
\text { site and downstream } \\
\text { BamHI recognition } \\
\text { site }\end{array}$} & \multirow{2}{*}{$\begin{array}{l}\text { This } \\
\text { study }\end{array}$} \\
\hline PecpR BamHI R & $\begin{array}{l}\text { GAGAGAGGATCCATGTCACTACTT } \\
\text { TCCAAACCTGTA }\end{array}$ & & & \\
\hline pMC1403 F & TGCCACCTGACGTCTAAGAA & \multirow{3}{*}{$48^{\circ} \mathrm{C}$} & \multirow{3}{*}{$\begin{array}{l}\text { Multiple cloning } \\
\text { region of pMC1403 }\end{array}$} & \multirow{3}{*}{38} \\
\hline & 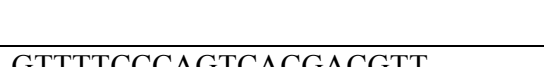 & & & \\
\hline pMC1403 R & GTTTTCCCAGTCACGACGTT & & & \\
\hline
\end{tabular}

* "A. Temp." refers to annealing temperature of a primer set

** "check" is in reference to these primers use as a means to versify successful integration of the kanamycin resistance cassette 


\subsection{Construction of beta-galactosidase promoter fusion construct}

\subsubsection{Primer design and PCR amplification of ECP promoter region}

In order to observe ecpR promoter activity under different environmental conditions, the ecpR promoter region was placed upstream of a promoter-less gene encoding beta-galactosidase. Activity of the promoter region may then be assessed through the levels of beta-galactosidase activity in a sample. Primers were designed to amplify the promoter region for the ECP operon that upon amplification would contain an upstream XmaI recognition sequence and a downstream BamHI recognition sequence (see table 2.4 for details). These restriction enzymes were selected because of their presence in the multiple cloning site in front of the promoter-less lac $Z$ gene of pMC1403. The primers were also designed to ensure that upon ligation of this region into pMC1403, the first three codons of $e c p R$ would be in the same reading frame as the aforementioned lacZ gene. The promoter region was amplified with a PCR reaction with the same components and cycling conditions as described in section 2.2.1. After completion of PCR, the samples were subjected to spin column PCR cleanup (GE Healthcare).

\subsubsection{Restriction digestion and vector dephosphorylation}

Both the cleaned promoter region and an aliquot of a miniprep of pMC1403 underwent simultaneous digestion with both XmaI (New England Biolabs) and BamHI (New England Biolabs), each in a 50uL restriction reaction composed as follows: $5 \mathrm{uL}$ 10X NEBuffer 3 (New England Biolabs), 0.5uL 100X BSA (New England Biolabs), 1uL XmaI, 1uL BamHI, 3uL DNA ( 1ug), and sterile distilled water to achieve a final volume of $50 \mathrm{uL}$. This mixture was incubated at $37^{\circ} \mathrm{C}$ for 1 hour. The now digested pMC1403 was subjected to dephosphorylation with Antarctic phosphatase (New England Biolabs) with the addition of 5uL 10X Antarctic phosphatase buffer and 1uL Antarctic phosphatase and incubated at $37^{\circ} \mathrm{C}$ for 20 minutes. Both samples were then subjected to spin column enzymatic reaction cleanup. 


\subsubsection{Ligation}

To successfully assemble the beta-galactosidase promoter construct through ligation of the ecpR promoter region into the multiple cloning site of pMC1403, A $20 \mathrm{uL}$ ligation mixture was prepared as follows: $4 \mathrm{uL} 5 \mathrm{X}$ ligase reaction buffer, $3 \mathrm{uL}$ digested and dephosphorylated pMC1403, 11uL digested ECP promoter region, $1 \mathrm{U}$ in $1 \mathrm{uL} \mathrm{T}_{4}$ DNA ligase, $1 \mathrm{uL}$ sterile distilled water. This mixture was incubated at room temperature for 1 hour, and then diluted with $80 \mathrm{uL}$ of sterile distilled water.

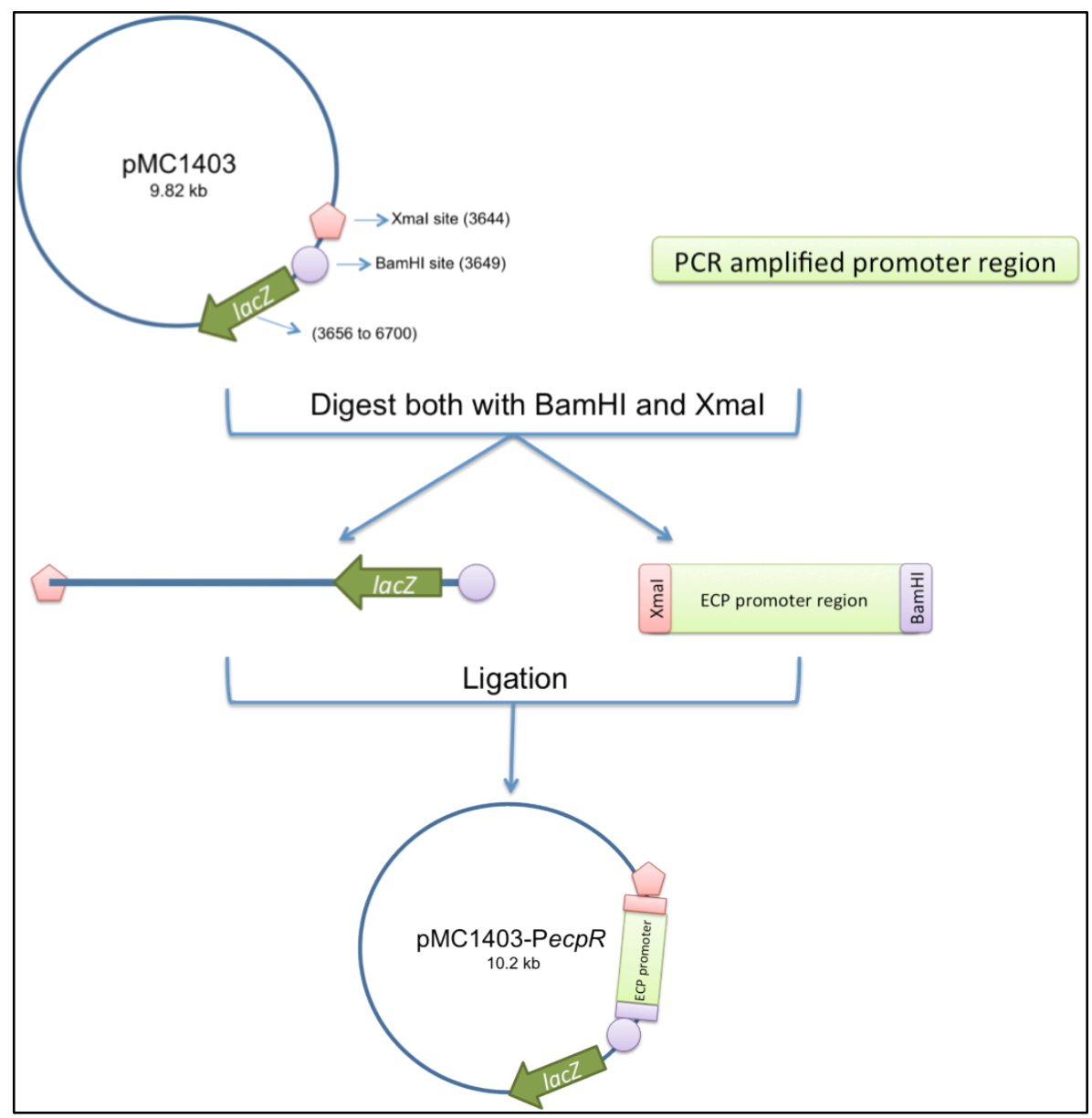

Figure 2.2: Overview of creation of pMC1403-PecpR. Summary image of sections 2.3.1-2.3.3. Parental plasmid, pMC1403, and PCR amplified promoter region for ecp operon are both digested with BamHI and Xmal, the sticky ends of pMC1403 were dephosphorylated with Antarctic phosphatase, and subsequently the promoter region and plasmid were ligated such that the ecp operon promoter region was inserted in front of promoter-less lacZ of pMC1403. 


\subsubsection{Transformation of TOP10 chemically competent $E$. coli and isolation of pMC1403-PecpR}

The ligation reaction from section 2.3.3 was used to transform chemically competent $E$. coli so that potentially successful ligation products could be identified based on conference of ampicillin resistance. $100 \mathrm{uL}$ of TOP10 chemically competent $E$. coli was thawed on ice for 10 minutes. $20 \mathrm{uL}$ of dilute ligation reaction was added to the cells, which were kept on ice for an additional 20 minutes. The cells were then incubated at $37^{\circ} \mathrm{C}$ for 5 minutes, and then placed back on ice for 1 minute. $500 \mathrm{uL}$ of SOC media was added to the cells, followed by 1 hour recovery period at $37^{\circ} \mathrm{C}$ with shaking. $100 \mathrm{uL}$ of the transformed cells were plated onto LB-Amp. Resulting colonies were subjected to colony PCR, as described in section 2.2.5, with primers pMC1403 F and pMC1403 R. Positive results were confirmed with sequence analysis. Electrocompetent EDL933 and EDL933 $h n s:: k a n^{\mathrm{r}}$ were both transformed with the final construct.

\subsection{Acid stress treatment, AA30}

Overnight cultures were grown in $10 \mathrm{~mL}$ LB broth, with antibiotics when needed, at $37^{\circ} \mathrm{C}$ with shaking. $1.5 \mathrm{~mL}$ of the overnight culture was subcultured into $8.5 \mathrm{~mL}$ of high glucose (4.5 g/L) Dubellco's Minimal Media (DMEM) supplemented with 25mM MOPS, adjusted to $\mathrm{pH} 7.4$ from 7.8 with concentrated hydrochloric acid $(\mathrm{HCl})$. For each strain, two such subcultures were made. The subcultures were incubated at $37^{\circ} \mathrm{C}$ with shaking for approximately 3 hours, or until the $\mathrm{OD}_{600}$ was $0.4-0.6$. The subcultures were then centrifuged at $2630 \mathrm{x} \mathrm{g}(3500 \mathrm{rpm})$ at $4^{\circ} \mathrm{C}$ for 10 minutes. The supernatants were discarded. For each strain, one bacterial pellet was resuspended in $10 \mathrm{~mL}$ of control DMEM, and the other in $10 \mathrm{~mL}$ of acid adaptation DMEM. "Control DMEM" was buffered with $25 \mathrm{mM}$ MOPS and adjusted to $\mathrm{pH} 7.4$ from 7.8 with concentrated $\mathrm{HCl}$. "Acid adaptation DMEM" was buffered with 25mM MES and adjusted to $\mathrm{pH} 5.0$ from 7.8 with concentrated $\mathrm{HCl}$. These acid adaptation subcultures were incubated for 1 hour at $37^{\circ} \mathrm{C}$ with $5 \% \mathrm{CO}_{2}$. These acid adaptation and control subcultures were re-spun as described before, and the supernatants were again discarded. The bacterial pellets previously resuspended in control DMEM were again resuspended in $10 \mathrm{~mL}$ of control 
DMEM. The bacterial pellets previously resuspended in acid adaptation were resuspended in $10 \mathrm{~mL}$ of acid stress DMEM. Acid stress DMEM was unbuffered and adjusted to $\mathrm{pH} 3.0$ from 7.8 with concentrated $\mathrm{HCl}$. These acid stress and control subcultures were incubated for 30 minutes at $37^{\circ} \mathrm{C}$ with $5 \% \mathrm{CO}_{2}$. These acid stress and control subcultures were re-spun as described before, and the supernatants were again discarded. All bacterial pellets were resuspended in 10mL sterile 1X PBS, and re-spun as described before. The supernatant was discarded, and this PBS wash step was repeated a second time. The resulting bacterial pellets were then either freshly prepared for SDSPAGE and Western blot analysis, stored at $-80^{\circ} \mathrm{C}$ prior to SDS-PAGE sample preparation, or analyzed for promoter activity in beta-galactosidase assays.

\subsection{Short-chain fatty acid (SCFA) stress treatment}

Initial cultures of each strain were started in $5 \mathrm{~mL}$ of LB broth, with antibiotics added as needed, incubated for 5-6 hours at $37^{\circ} \mathrm{C}$ with shaking. After 5-6 hours, the $\mathrm{OD}_{600}$ value was taken for each strain and based on those values the amount of culture needed to obtain a $10 \mathrm{~mL}$ subculture with an initial $\mathrm{OD}_{600}$ value of 0.01 was calculated. This volume was added to two centrifuge tubes for each strain and centrifuged at $2630 \mathrm{x}$ $\mathrm{g}(3500 \mathrm{rpm})$ at $18^{\circ} \mathrm{C}$ for 10 minutes. The supernatant was discarded. One sample for each strain served as the control sample and was resuspended in $10 \mathrm{~mL}$ of LB broth, with antibiotics added as needed. The other sample for each strain served as the SCFA stressed sample and was resuspended in $9.5 \mathrm{~mL}$ of LB broth and $0.5 \mathrm{~mL}$ of $20 \mathrm{X} 90 \mathrm{mM}$ SCFA mix, with antibiotics added as needed. The 20X 90mM SCFA solution was made up in miliQfiltered water. At a $1 \mathrm{X}$ concentration in either LB or DMEM, the 90mM SCFA mix included $60.5 \mathrm{mM}$ sodium acetate, $24.5 \mathrm{mM}$ sodium propionate, and $3 \mathrm{mM}$ sodium butyrate. All samples were incubated overnight at $37^{\circ} \mathrm{C}$ with shaking. The following morning, all samples were diluted. For the control samples previously incubated in only LB broth, $1 \mathrm{~mL}$ of the overnight subculture was added to $7 \mathrm{~mL}$ of DMEM buffered with $100 \mathrm{mM}$ pH 6.7 MOPS, with antibiotics added as needed. For the SCFA stressed samples previously incubated with $90 \mathrm{mM}$ SCFA LB broth, $1 \mathrm{~mL}$ of the overnight subculture was added to $7 \mathrm{~mL}$ of $90 \mathrm{mM}$ SCFA DMEM buffered with $100 \mathrm{mM}$ pH 6.7 MOPS. All samples were then incubated at $37^{\circ} \mathrm{C}$ with $5 \% \mathrm{CO}_{2}$ for 2 hours. After this incubation, all samples 
were re-spun as described before. The supernatant was discarded, and the bacterial pellets all resuspended in $8 \mathrm{~mL}$ sterile $1 \mathrm{X}$ PBS and re-spun as described before. This PBS wash step was repeated a second time. The resulting bacterial pellets were then either freshly prepared for SDS-PAGE and Western blot analysis, stored at $-80^{\circ} \mathrm{C}$ prior to SDS-PAGE sample preparation, or analyzed for promoter activity in beta-galactosidase assays.

\subsection{Beta-galactosidase promoter activity assays}

After either acid stress, strains carrying either pMC1403 or pMC1403-PecpR were assayed for levels of beta-galactosidase activity ${ }^{49}$. The final $\mathrm{OD}_{600}$ values were taken for each sample, and 20uL of acid or SCFA stressed sample was added to $80 \mathrm{uL}$ of permeabilization solution $\left(100 \mathrm{mM} \mathrm{Na}_{2} \mathrm{HPO}_{4}, 20 \mathrm{mM} \mathrm{KCl}, 2 \mathrm{mM} \mathrm{MgSO} 4,0.8 \mathrm{mg} / \mathrm{mL}\right.$ hexadecyltrimethylammonium bromide (CTAB), $0.4 \mathrm{mg} / \mathrm{mL}$ sodium deoxycholate, $5.4 \mu \mathrm{L} / \mathrm{mL}$ beta-mercaptoethanol) in a 96 -well flat bottom plate ${ }^{49,83}$. Samples were then incubated at $30^{\circ} \mathrm{C}$ for 30 minutes. $25 \mathrm{uL}$ of each sample was transferred to a new well on the 96 -well plate, and $150 \mathrm{uL}$ of substrate solution $\left(60 \mathrm{mM} \mathrm{Na}_{2} \mathrm{HPO}_{4}, 40 \mathrm{mM} \mathrm{NaH}_{2} \mathrm{PO}_{4}\right.$, $1 \mathrm{mg} / \mathrm{mL}$ o-nitrophenyl-beta-D-Galactoside (ONPG), $2.7 \mu \mathrm{L} / \mathrm{mL}$ beta-mercaptoethanol) was added to each sample to start the enzymatic reaction ${ }^{49,83}$. The absorbance of each sample was recorded at $414 \mathrm{~nm}$ at 10-minute intervals, for a total of 2 hours. Miller units were calculated as follows ${ }^{83}$ :

$$
\text { Miller Units }=1000 \times \frac{\text { Absorbance }_{414}}{\text { OD } 600 \times \text { reaction volume }(\mathrm{mL}) \times \text { reaction time (minutes) }^{-}}
$$




\subsection{Western blotting}

\subsubsection{Sample preparation}

Specialized SDS-PAGE sample preparation was needed in order to visualize EcpA monomers with western blotting. Exact volumes varied between acid and SCFA stressed samples, but the following volumes are given based on $10 \mathrm{~mL}$ of original sample. Bacterial pellets obtained, either fresh or previously stored at $-80^{\circ} \mathrm{C}$, were resuspended in $180 \mathrm{uL}$ autoclaved distilled water adjusted with concentrated $\mathrm{HCl}$ to $\mathrm{pH}$ 1.5. The resuspended sample was transferred to a microcentrifuge tube and placed in a heating block at $95^{\circ} \mathrm{C}$ for 5 minutes. $20 \mathrm{uL} 20 \% \mathrm{w} / \mathrm{v}$ SDS was added for a final concentration of $2 \%$ SDS, and the samples were incubated at $95^{\circ} \mathrm{C}$ for 10 minutes. At this point, a total of $15 \mathrm{uL}$ was removed to determine the total protein concentration of each sample through a standard BCA assay. BSA standards used in these assays also contained a final SDS concentration of $2 \% .49 \mathrm{uL}$ of $5 \mathrm{X}$ SDS-free sample buffer (10mM beta-mercaptoethanol, $20 \% \mathrm{v} / \mathrm{v}$ glycerol, $0.2 \mathrm{M}$ Tris- $\mathrm{HCl}$ of $\mathrm{pH} 6.8$ and $0.05 \% \mathrm{w} / \mathrm{v}$ bromophenol blue) was added to samples, resulting in yellow or orange samples. Samples were then neutralized with $8 \mathrm{uL} 1 \mathrm{~N} \mathrm{NaOH}$, confirmed with the sample color changing to a dark navy blue. Samples were again incubated at $95^{\circ} \mathrm{C}$ for 5 minutes, then stored at $-20^{\circ} \mathrm{C}$ until needed.

\subsubsection{SDS-PAGE and transfer}

Samples were separated through SDS-PAGE on gels with an $6 \%$ polyacrylamide stacking gel $(2.6 \mathrm{~mL}$ distilled water, $1 \mathrm{~mL} 30 \%$ acrylamide/bisacrylamide mix, $2 \mathrm{~mL} 1.5 \mathrm{M}$ Tris-HCl pH 8.8, 40uL 20\% SDS, 50uL 10\% APS, 5uL TEMED) and a 15\% polyacrylamide resolving gel $(1.8 \mathrm{~mL}$ distilled water, $4 \mathrm{~mL} 30 \%$ acrylamide/bisacrylamide mix, $1.25 \mathrm{~mL}$ 0.5M Tris-HCl pH 6.8, 25uL 20\% SDS, 80uL 10\% ammonium persulfate (APS), 8uL TEMED). Gels were run in a BioRad apparatus at a constant voltage of $150 \mathrm{~V}$ for 90 minutes in $1 \mathrm{X}$ SDS-PAGE running buffer $(25 \mathrm{mM}$ Tris- $\mathrm{HCl} \mathrm{pH} 8.3,200 \mathrm{mM}$ glycine, $0.1 \%$ SDS). Molecular weight standards were run along with samples, throughout this study several commercial molecular weight standards were used: PiNK Plus Pre-stained Protein Ladder (FroggaBio), Precision Plus Protein Western Blot Standard (BioRad), and Prescision Plus Protein All Blue Standards (BioRad). The 
separated proteins were then transferred to a polyvinylidene fluoride membrane overnight at $4^{\circ} \mathrm{C}$ at a constant voltage of $30 \mathrm{~V}$ in $1 \mathrm{X}$ transfer buffer $(25 \mathrm{mM}$ Tris- $\mathrm{HCl} \mathrm{pH} 8.3$, $200 \mathrm{mM}$ glycine, $20 \% \mathrm{v} / \mathrm{v}$ methanol). After transfer, the gel was stained for 30 minutes in Biosafe Coomassie stain, and destained for 1 hour in distilled water, to ensure a successful transfer.

\subsubsection{Western blotting}

After transfer, membranes were incubated in a blocking solution (1X PBST with $5 \% \mathrm{w} / \mathrm{v}$ non-fat powdered milk) for 1 hour at room temperature with gentle shaking. The membranes were then washed twice for 5 minutes each wash in 1X PBST at room temperature with gentle shaking. Polyclonal $\alpha$-EcpA, kindly provided by Dr. Jorge Girón from the University of Florida, was applied to washed membranes at a dilution of 1:3000 in 1X PBST and incubated with membranes overnight at $4^{\circ} \mathrm{C}$ with gentle shaking. The membranes were then washed again as described before, twice for 5 minutes each and then three times for 10 minutes each. Lanes containing a sample of Precision Plus Protein Western Blot Standard (BioRad), made up of Strep tagged recombinant proteins, were separated from the rest of the blot and incubated with horseradish peroxidase conjugated StrepTactin diluted 1:5000 in PBST and incubated for 1 hour at room temperature.Horseradish peroxidase (HRP) conjugated goat-anti-rabbit was diluted 1:10,000 in 1X PBST and incubated with the remaining membrane for 1 hour at room temperature with gentle shaking. The blots were again washed five times as described before. An enhanced chemiluminscence (ECL) solution was applied to the blot for a total exposure time of 5 minutes and the results were visualized on either x-ray film or a gel doc with chemiluminescent capabilities.

\subsection{Statistical analysis}

All figures are presented as the mean \pm standard deviation. One-way ANOVA, performed with Prism 6, was used to determine significance, with $\mathrm{P}$ value $\leq 0.05$ considered significant. 


\section{Results}

\section{1: Construction of EDL933 isogenic mutants}

In this study, two regulatory proteins, H-NS and UvrY, were suspected of playing a role in regulating expression of EcpA under acid or SCFA stress. Isogenic mutants lacking these genes were created in order to potentially understand how EcpA is regulated under acid or SCFA stress; more specifically to determine if the previously observed increases in EcpA expression were modulated by those regulators. Additionally it was also necessary to create an isogenic mutant lacking eсрA to serve as a negative control.

Homologous recombination was the method used to produce the isogenic mutants; specifically $\lambda$-red recombinase mediated homologous recombination ${ }^{16}$. First, EDL933 was transformed with pKD46, a temperature sensitive plasmid that encodes $\lambda$ red recombinase. Next, primers were designed which would amplify the kanamycin resistance cassette present on $\mathrm{pKD} 4$, but which also contained regions homologous to the region of EDL933 genomic DNA just upstream and downstream of the target gene. Highfidelity PCR yielded linear portions of DNA that were then used to transform EDL933 (pKD46) via electroporation. Following a recovery period, samples were plated on LBKan plates and candidate colonies were screened via colony PCR for successful integration of the kanamycin cassette, indicating replacement of the target gene (Figures 3.1, 3.2, and 3.3). Colonies that appeared to contain the kanamycin resistance cassette were submitted for sequence analysis to further confirm the replacement of the target gene (Figures 3.4, 3.5, and 3.6). 


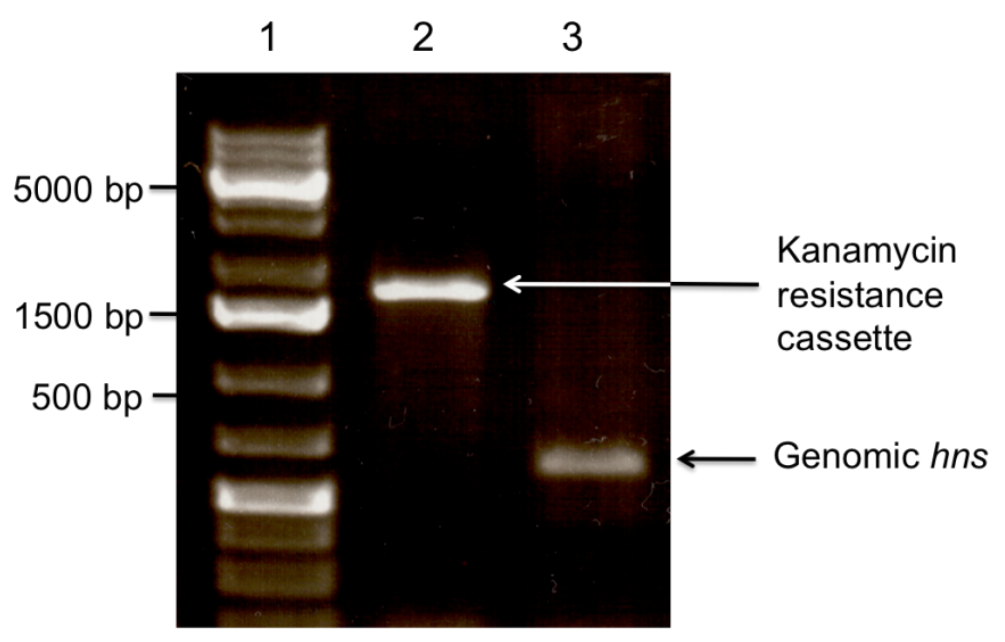

Figure 3.1: PCR confirmation of kanamycin cassette in EDL933 hns::Kan ${ }^{\mathrm{R}}$.

The lane contents were as follows: 1 - molecular weight standard, 2 - EDL933 $h n s:: \operatorname{Kan}^{\mathrm{R}}, 3$ - EDL933. The primers used to generate these products (hns check $\mathrm{F}$ and hns check R) were specific to a region outside of genomic hns in EDL933. The band in lane $2(\sim 1500 \mathrm{bp})$ is significantly larger than the faint band in lane $3(\sim 500 \mathrm{bp})$ due to the integration of the kanamycin resistance cassette from pKD4 (950 bp) in place of genomic hns (414 bp).

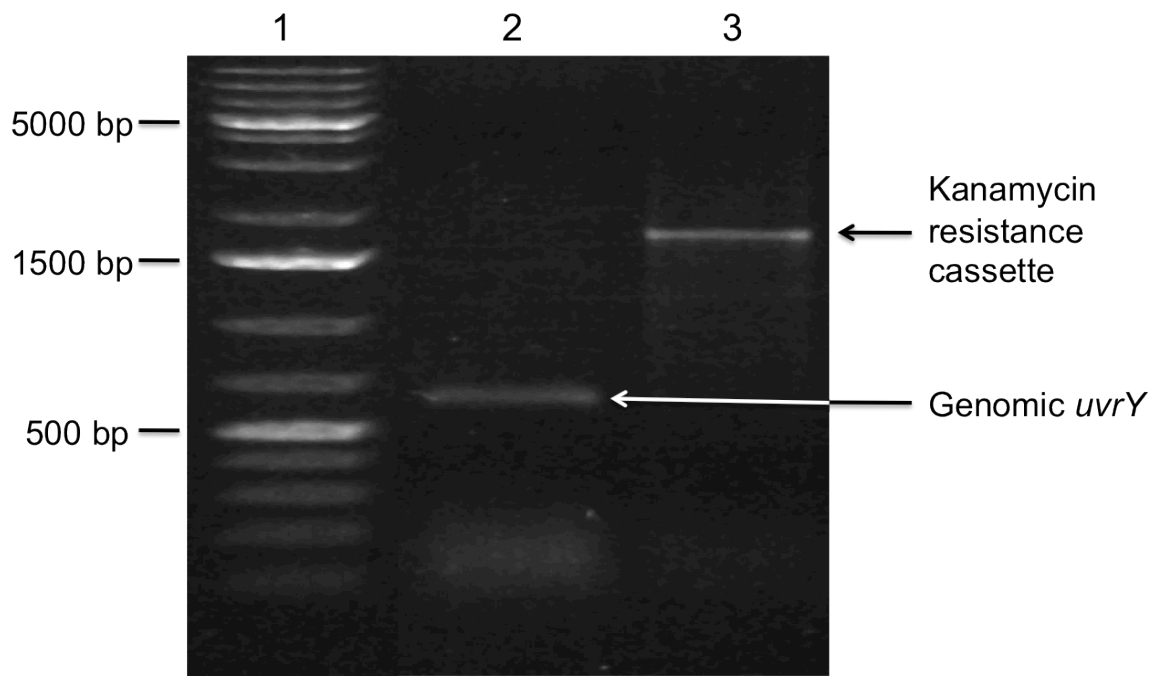

Figure 3.2: PCR confirmation of kanamycin cassette in EDL933 uvrY::Kan ${ }^{\mathrm{R}}$.

The lane contents were as follows: 1 - molecular weight standard, 2 - EDL933, 3 EDL933 $u v r Y:: \mathrm{Kan}^{\mathrm{R}}$. The primers used to generate these products (uvr $Y$ check $\mathrm{F}$ and $u v r Y$ check R) were specific to a region outside of genomic $u v r Y$ in EDL933. The band in lane $3(\sim 1500 \mathrm{bp})$ is significantly larger than the band in lane $2(\sim 600 \mathrm{bp})$ due to the integration of the kanamycin resistance cassette from pKD4 (950 bp) in place of genomic $u v r Y(657 \mathrm{bp})$. 


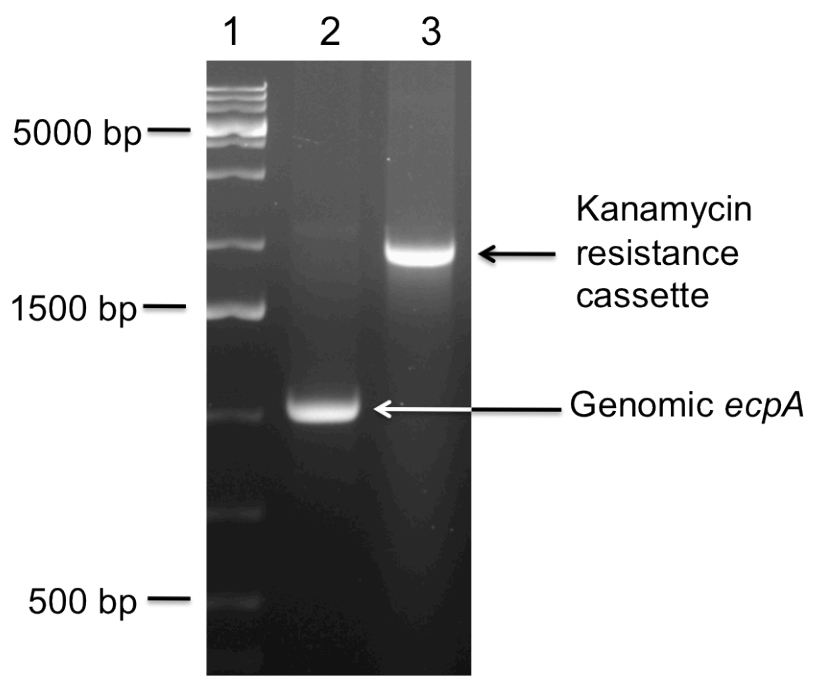

Figure 3.3: PCR confirmation of kanamycin cassette in EDL933 ecpA::Kan ${ }^{\mathrm{R}}$.

The lane contents were as follows: 1 - molecular weight standard, 2 - EDL933, 3 EDL933 ecp $A:: \mathrm{Kan}^{\mathrm{R}}$. The primers used to generate these products (ecp $A$ check $\mathrm{F}$ and ecp $A$ check R) were specific to a region outside of genomic ecp $A$ in EDL933. The band in lane $3(\sim 1800 \mathrm{bp})$ is significantly larger than the band in lane $2(\sim 1000 \mathrm{bp})$ due to the integration of the kanamycin resistance cassette from pKD4 $(950 \mathrm{bp})$ in place of genomic ecpA (588 bp). 


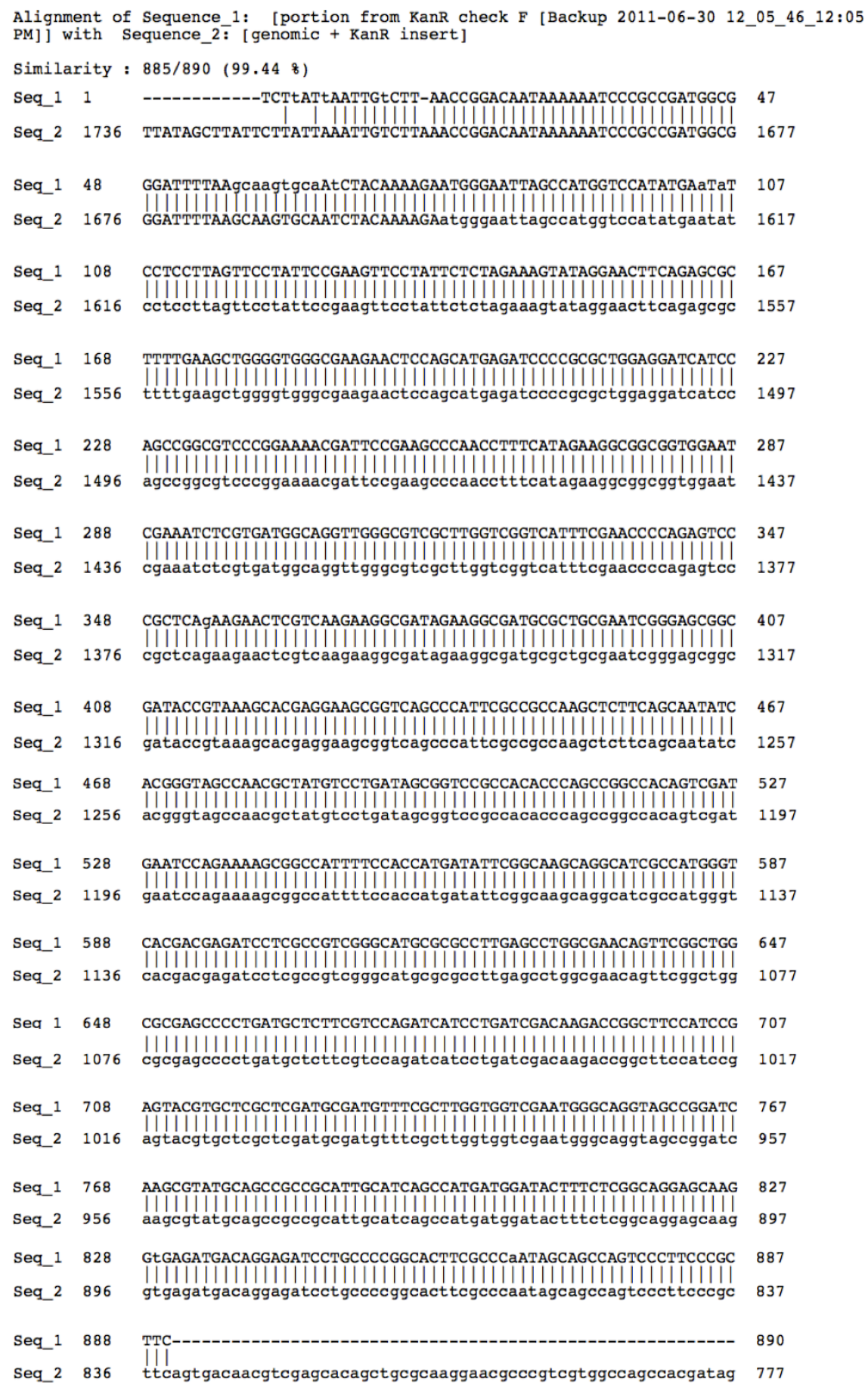

Figure 3.4: Sequence alignment result for EDL933 hns::Kan ${ }^{\mathrm{R}}$.

Seq 1 is representative of the sequence obtained from the candidate strain, while Seq 2 is representative of the desired EDL933 genomic sequence after successful replacement of hns with a kanamycin resistance cassette. The results, obtained with SerialCloner 2-6, confirmed the replacement of EDL933 genomic hns with the kanamycin resistance cassette of pKD4. 


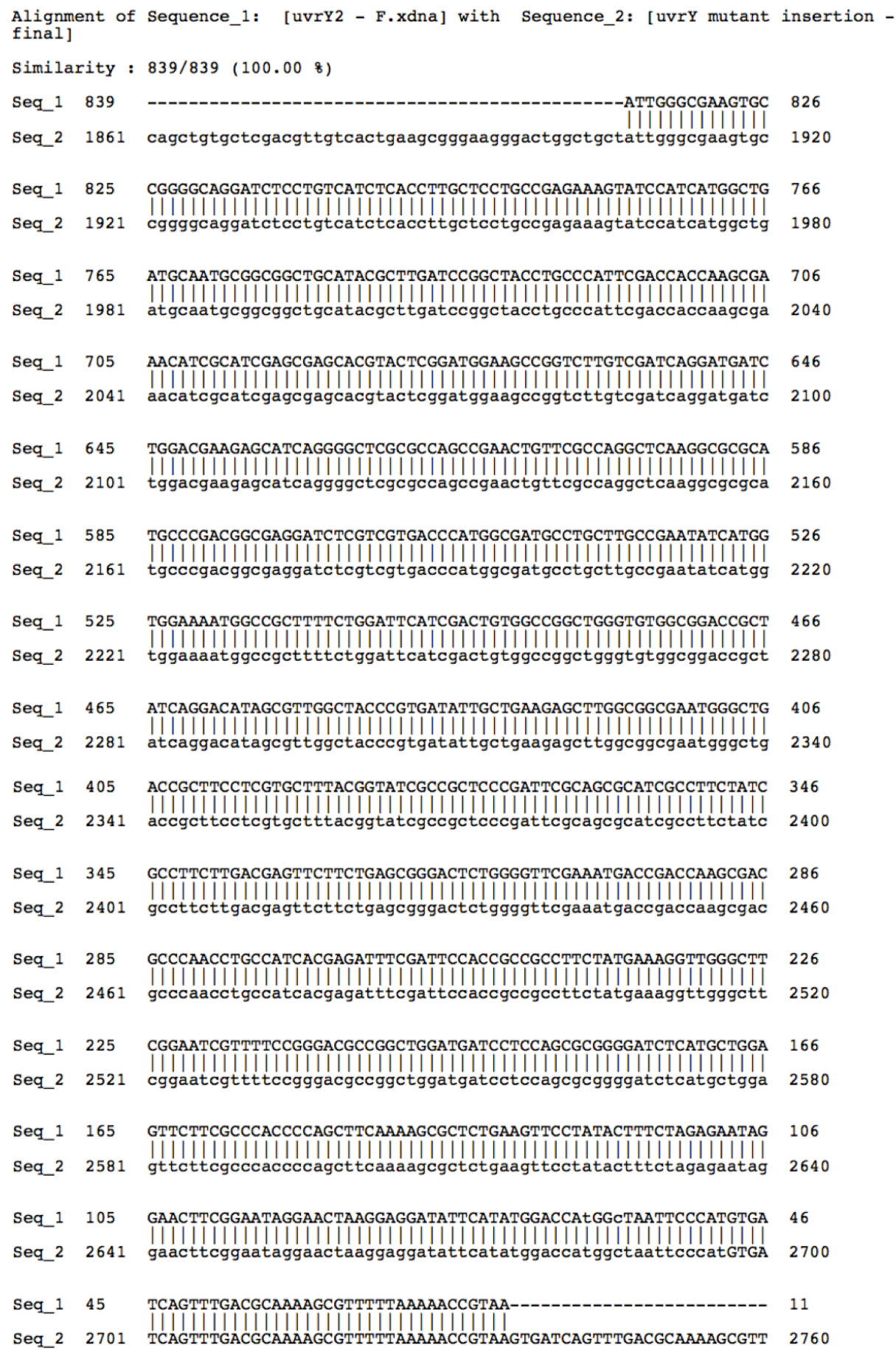

\section{Figure 3.5: Sequence alignment result for EDL933 $u v r Y:: \operatorname{Kan}^{\mathrm{R}}$.}

Seq 1 is representative of the sequence obtained from the candidate strain, while Seq 2 is representative of the desired EDL933 genomic sequence after successful replacement of $u v r Y$ with a kanamycin resistance cassette. The results, obtained with SerialCloner 26, confirmed the replacement of EDL933 genomic $u v r Y$ with the kanamycin resistance cassette of pKD4. 


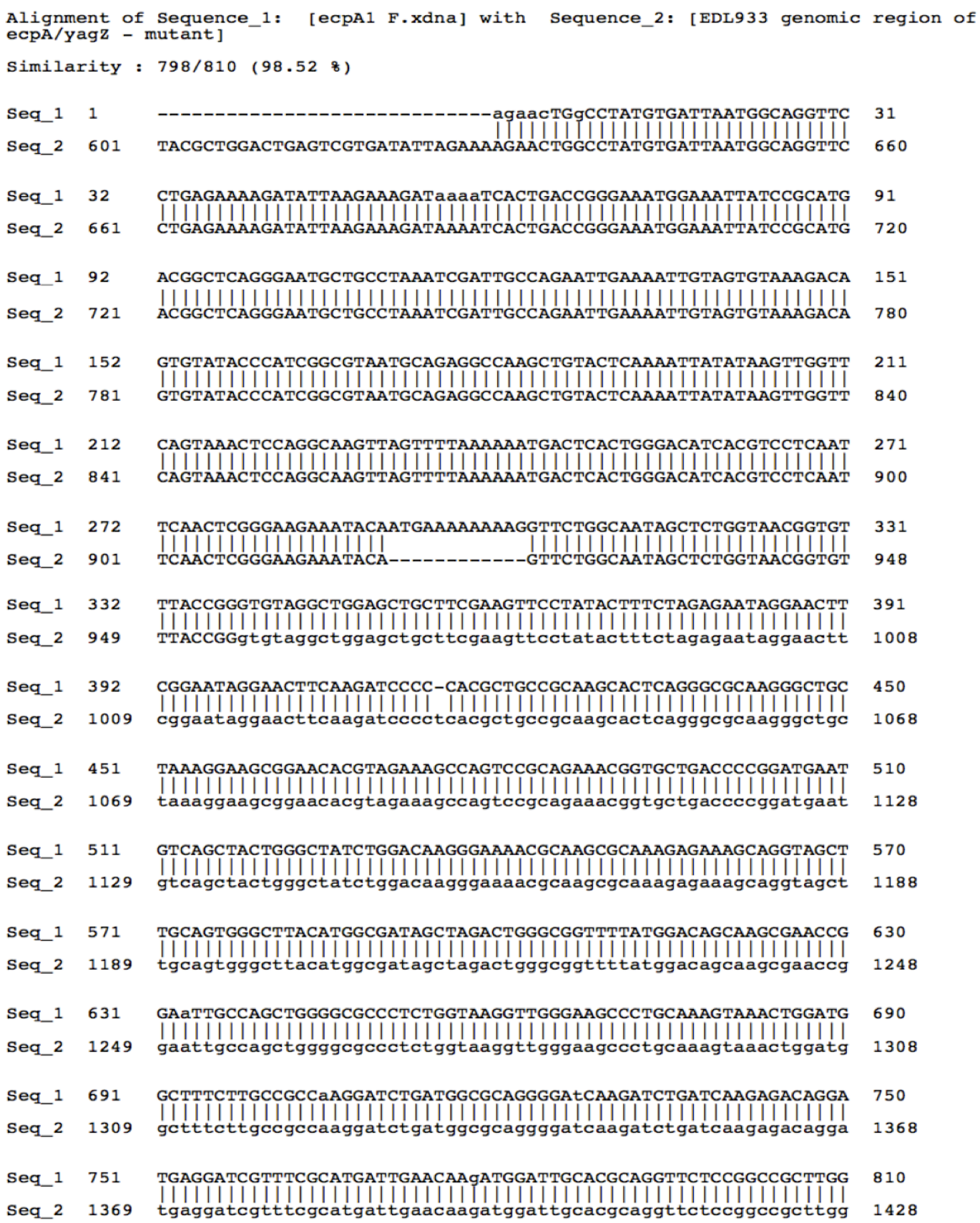

Figure 3.6: Sequence alignment result for EDL933 ecpA::Kan ${ }^{\mathrm{R}}$.

Seq 1 is representative of the sequence obtained from the candidate strain, while Seq 2 is representative of the desired EDL933 genomic sequence after successful replacement of ecpA with a kanamycin resistance cassette. The results, obtained with SerialCloner 26 , confirmed the replacement of EDL933 genomic ecpA with the kanamycin resistance cassette of pKD4. 


\section{2: EcpA Expression in Escherichia coli 0157:H7 EDL933 and isogenic mutants}

In order to confirm previously reported results of ecpA upregulation after acid stress, several varied attempts were made to observe expression of EcpA through Western blotting. It was reported by another group that simply boiling bacterial lysates in Laemmli buffer was insufficient to separate ECP into EcpA monomers, so for the most part, whole cell lysates were prepared by boiling pelleted EHEC in acidic water, $\mathrm{pH} 1.5$, before the addition of Laemmli buffer ${ }^{47,58}$. The lysates were neutralized with $1 \mathrm{~N}$ $\mathrm{NaOH}^{47,58}$.

The results observed were in agreement with those which have been previously reported, and can be summarized as follows: EcpA expression was only observed during growth in minimal media (DMEM) and never in LB, regardless of temperature or atmosphere, and EcpA expression was most evident in samples grown statically at $26^{\circ} \mathrm{C}$ without $\mathrm{CO}_{2}$ for at least 11 hours. It should be noted that the image is indicative of only two experiments and these results were more often not observed in replicates (Figure 3.7, 3.9). Under most conditions tested, EDL933 hns:: $\operatorname{Kan}^{\mathrm{R}}$ demonstrated a strong band of approximately $21 \mathrm{kDa}$, even when a comparable band was not detected in EDL933. However due to the presence of many non-specific bands for those samples, and the lack of an hns/ecpA double mutant, it cannot be confirmed that this band was specific to EcpA (Figure 3.8). EDL933 uvrY::Kan ${ }^{\mathrm{R}}$ was observed to have a profile of protein expression similar to that EDL933ecpA::Kan ${ }^{\mathrm{R}}$ when visualized with $\alpha$-EcpA antibodies (Figure 3.9); but it should be noted that this result is only indicative of a single experiment and was not successfully replicated during this study. 


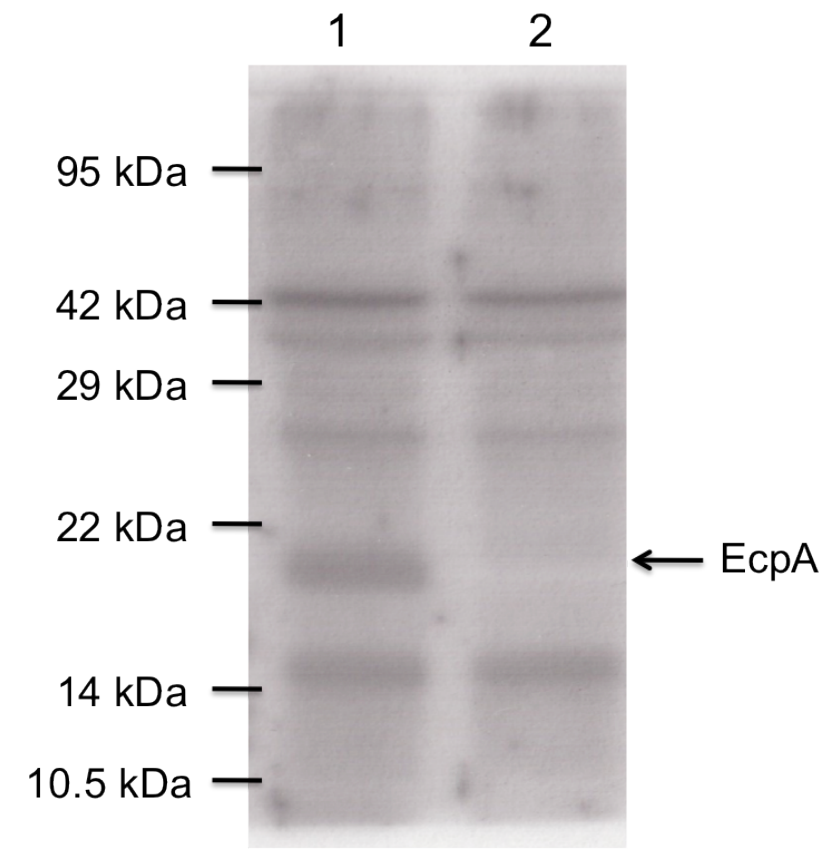

Figure 3.7: Western blotting of EcpA in EDL933 and EDL933 ecpA::Kan ${ }^{\mathrm{R}}$ with $\alpha$ EcpA. Whole cell lysates of EDL933 and EDL933 $\triangle$ ecpA::Kan ${ }^{\mathrm{R}}$ were prepared after overnight incubation at $37^{\circ} \mathrm{C}$ with shaking in LB followed by a static subculture in DMEM for 11 hours at $26^{\circ} \mathrm{C}$. Each lane was loaded with $90 \mu \mathrm{g}$ total protein. Blots were probed with rabbit $\alpha$-EcpA ( $1^{\circ}$ antibody) at a dilution of 1:3000 followed by HRPconjugated goat-anti-rabbit ( $2^{\circ}$ antibody) at a dilution of 1:10,000. The lane contents were: 1 - EDL933, 2 - EDL933 ecpA::Kan ${ }^{\mathrm{R}}$. A $21 \mathrm{kDa}$ protein is observed only the in the EDL933 sample, demonstrating that EcpA can be expressed by EDL933 in these particular conditions. 


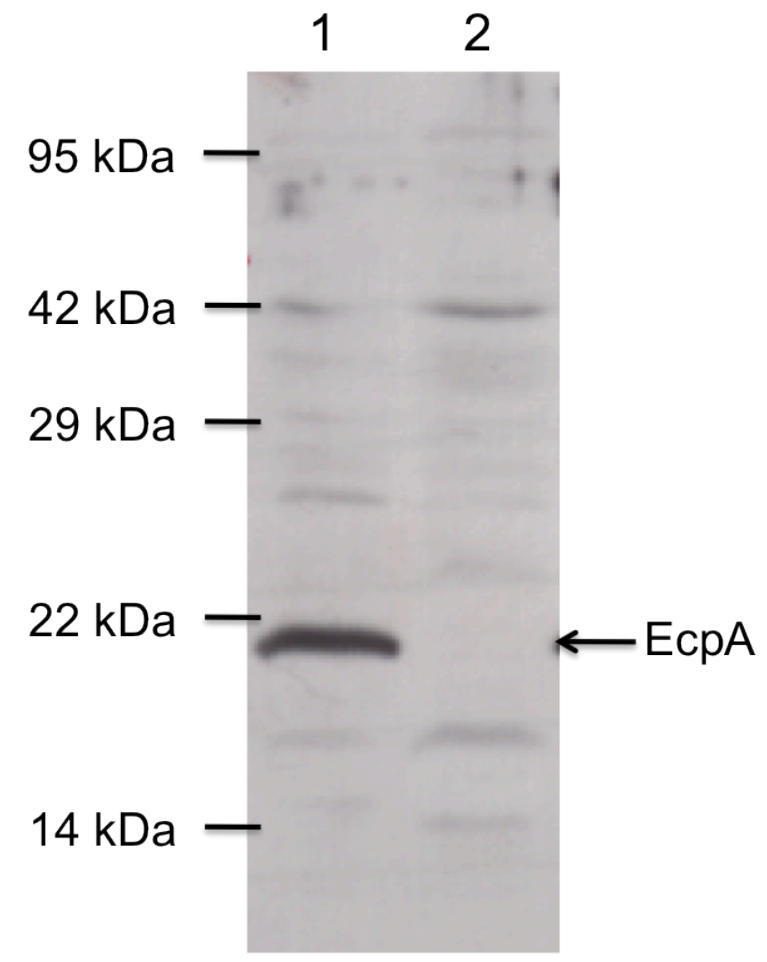

Figure 3.8: Western blotting of EcpA in EDL933 and EDL933 hns::Kan ${ }^{\mathrm{R}}$ with $\alpha$ EcpA. Whole cell lysates of EDL933 and EDL933 $h h n s:: \operatorname{Kan}^{\mathrm{R}}$ were prepared after overnight incubation at $37^{\circ} \mathrm{C}$ with shaking in LB followed by a static subculture in DMEM for 5 hours at $37^{\circ} \mathrm{C}$ with $5 \% \mathrm{CO}_{2}$. Each lane was loaded with $90 \mu \mathrm{g}$ total protein. Blots were probed with rabbit $\alpha$-EcpA ( $1^{\circ}$ antibody) at a dilution of $1: 3000$ followed by HRP-conjugated goat-anti-rabbit ( $2^{\circ}$ antibody) at a dilution of 1:10,000. The lane contents were: 1 - EDL933 hns::Kan ${ }^{\mathrm{R}}, 2$ - EDL933. A strong $21 \mathrm{kDa}$ protein is observed in the EDL933 hns::Kan ${ }^{\mathrm{R}}$ sample but not in the EDL933 sample, potentially demonstrating that conditions that do not lead to EcpA expression in EDL933 might still allow a strain lacking H-NS to express EcpA. 


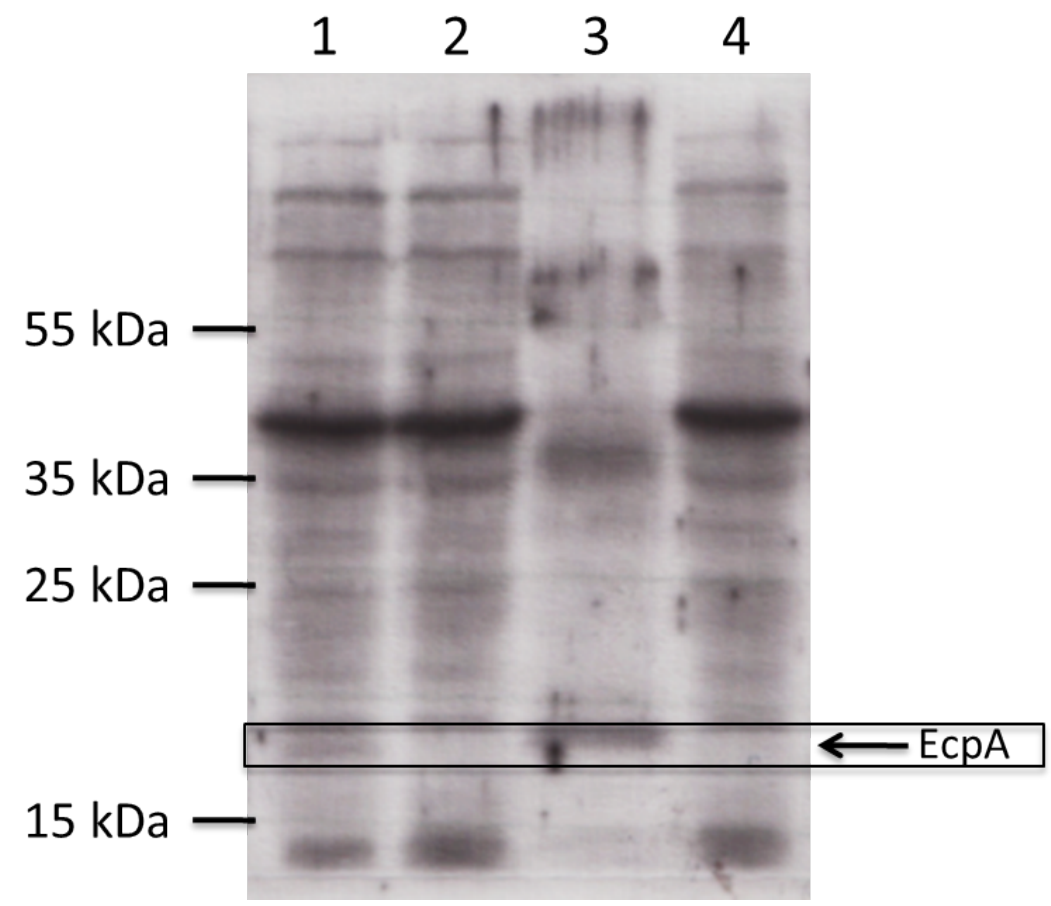

Figure 3.9: Western blotting of EcpA in EDL933 and isogenic mutants with $\alpha$-EcpA. Whole cell lysates of EDL933 and EDL933 $4 h n s: \mathrm{Kan}^{\mathrm{R}}$ were prepared after overnight incubation at $37^{\circ} \mathrm{C}$ with shaking in LB followed by a static subculture in DMEM for 11 hours at $26^{\circ} \mathrm{C}$. Each lane was loaded with $90 \mu \mathrm{g}$ total protein. Blots were probed with rabbit $\alpha$-EcpA ( $1^{\circ}$ antibody) at a dilution of 1:3000 followed by HRP-conjugated goatanti-rabbit ( $2^{\circ}$ antibody) at a dilution of 1:10,000. The lane contents were: 1 - EDL933, 2 - EDL933 ecpA::Kan ${ }^{\mathrm{R}}, 3$ - EDL933 $h n s: \operatorname{Kan}^{\mathrm{R}}, 4$ - EDL933 uvrY::KanR. A strong $21 \mathrm{kDa}$ protein is again observed in the EDL933 $h n s:: \mathrm{Kan}^{\mathrm{R}}$ sample however this time there is also a faint band, also $21 \mathrm{kDa}$, in the EDL933 that is not present in either the EDL933 ecpA::Kan ${ }^{\mathrm{R}}$ sample or the EDL933 uvrY::Kan ${ }^{\mathrm{R}}$ sample. This same result was observed in one of four replicates of this experiment. 


\section{3: Construction of $e c p R$ promoter fusion construct pMC1403- PecpR, and subsequent transformation of EDL933 and EDL933 hns::Kan ${ }^{\mathrm{R}}$}

A previous study has previously demonstrated the location of a promoter region for ecpR, and did so by integrating this promoter region upstream of a promoter-less chloramphenicol acetyltransferase (CAT) gene present, and performing routine CAT assays to observe promoter activity ${ }^{47}$. In this study, the majority of that promoter region was integrated upstream of a promoter-less gene encoding the enzyme beta-galactosidase (lacZ) on pMC1403. Construction of this promoter reporter construct makes it possible to observe changes in ecpR promoter activity under different environmental conditions, including acid or SCFA stress, as well as in isogenic regulatory mutants.

Primers were designed to amplify the promoter region from EDL933 genomic DNA, and were also designed to include recognition sites for BamHI and XmaI. Both the resulting PCR products and pMC1403 were digested with both BamHI and XmaI, followed by ligation and transformation of $\mathrm{DH} 5 \alpha$ and eventual plating of the transformation reactions on LB-Amp. Candidate colonies were screened via colony PCR for integration of the promoter region into pMC1403. Colonies that yielded positive results with PCR underwent mini-prep plasmid isolation, and subsequent sequence analysis to confirm successful in-frame integration of the promoter region (Figure 3.10). The final plasmid, now referred to as pMC1403-PecpR, was then used to transform both EDL933 and EDL933 hns::Kan ${ }^{\mathrm{R}}$ (Figures 3.11 and 3.12). 


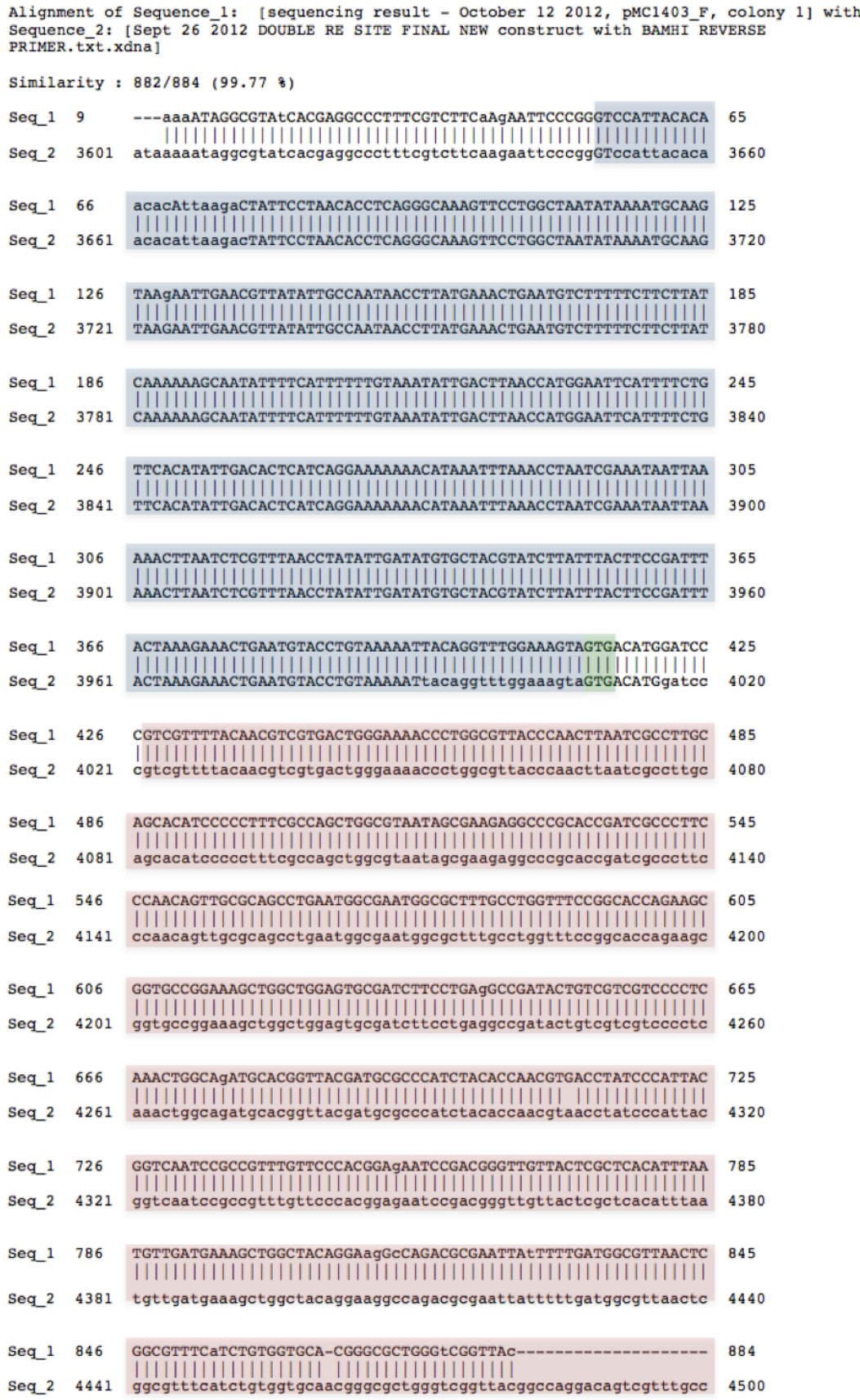

Figure 3.10: Sequence alignment result for pMC1403-PecpR.

Seq 1 is representative of the sequence obtained from the candidate plasmid, while Seq 2 is representative of the desired promoter construct sequence after successful integration of the ecpR promoter region into the BamHI and XmaI sites of pMC1403. Results, obtained with SerialCloner 2-6, confirmed the in-frame integration of the ecpR promoter region in front of the promoter-less lacZ present on pMC1403. Highlighted in blue is the inserted promoter region, in green in the ecpR start codon, and in red is lacZ. 


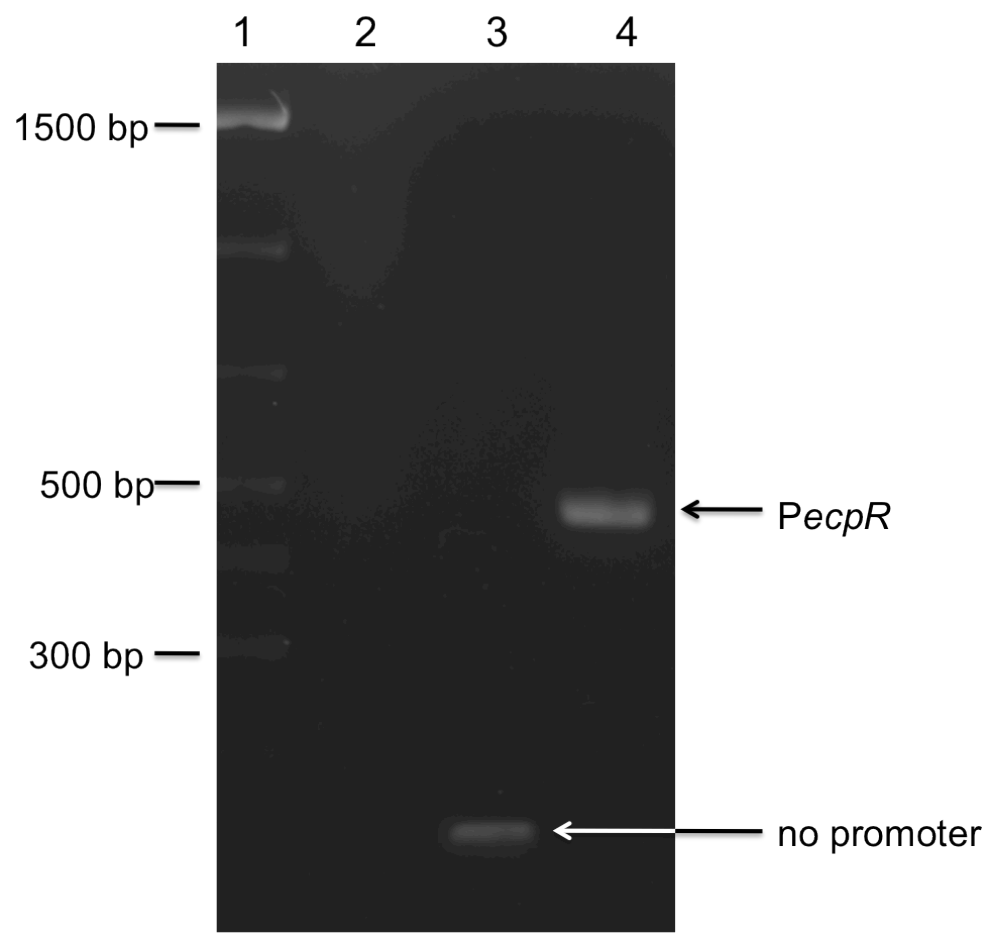

Figure 3.11: Colony PCR confirmation of transformation of EDL933 with pMC1403 and pMC1403-PecpR. The lane contents were as follows: 1 - molecular weight standard, 2 - EDL933, 3 - EDL933(pMC1403), 4 - EDL933(pMC1403-PecpR). The primers used to generate these products (pMC1403 F and pMC1403 R) were specific to regions just outside of the multiple cloning site of pMC1403. The band in lane 4 ( $\sim 500$ $\mathrm{bp})$ is significantly larger than the faint band in lane $3(\sim 130 \mathrm{bp})$ due to the insertion of the ecpR promoter region into the BamHI and $\mathrm{XmaI}$ sites of $\mathrm{pMC1403}$. The lack of a band in lane 2 confirms that either pMC1403 or pMC1403-PecpR served as template DNA for the PCR reaction, rather than EDL933 genomic DNA. 


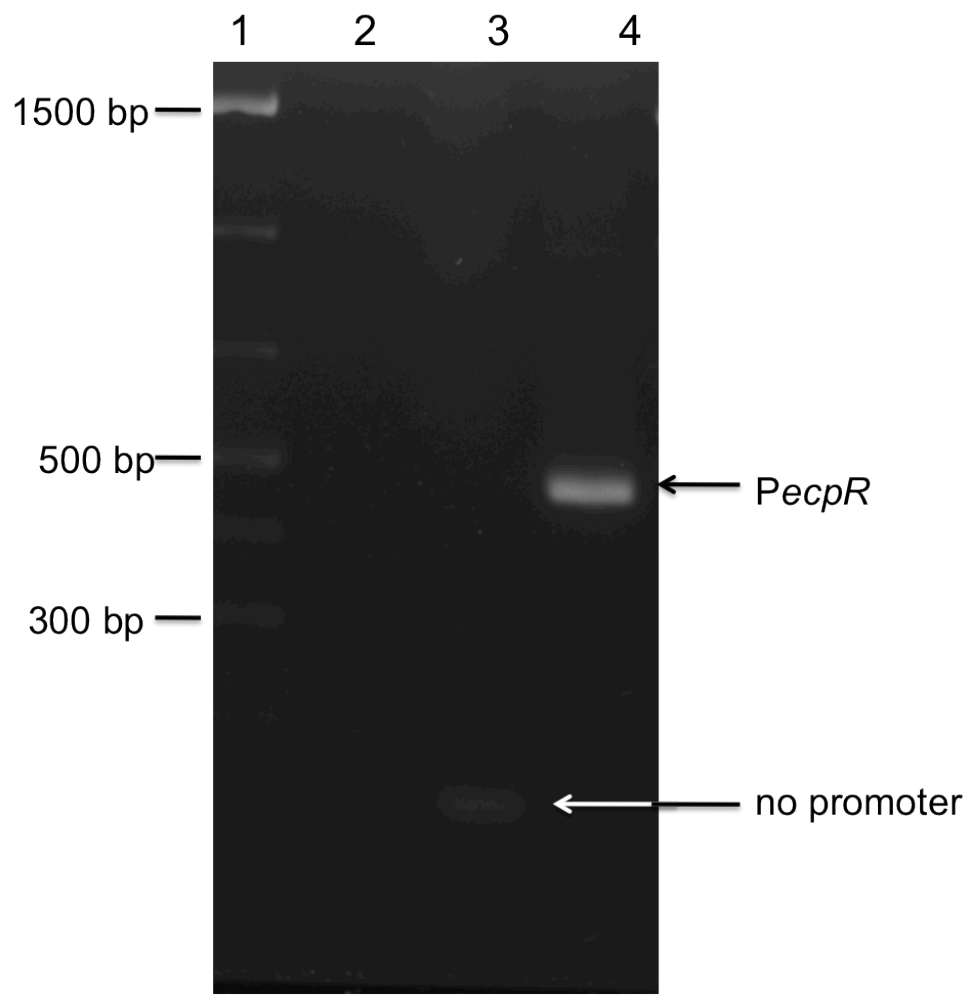

Figure 3.12: PCR confirmation of transformation of EDL933 hns::Kan $^{\mathrm{R}}$ with pMC1403 and pMC1403-PecpR. The lane contents were as follows: 1 - molecular

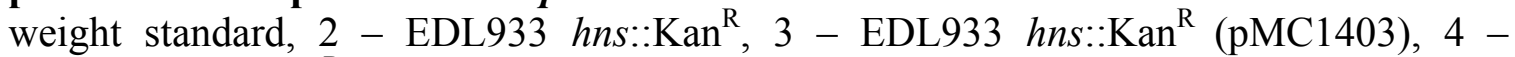
EDL933 hns::Kan ${ }^{\mathrm{R}}$ (pMC1403-PecpR). The primers used to generate these products (pMC1403 F and pMC1403 R) were specific to regions just outside of the multiple cloning site of pMC1403. The band in lane $4(\sim 500 \mathrm{bp})$ is significantly larger than the faint band in lane $3(\sim 130 \mathrm{bp})$ due to the insertion of the ecpR promoter region into the BamHI and XmaI sites of pMC1403. The lack of a band in lane 2 confirms that either pMC1403 or pMC1403-PecpR served as template DNA for the PCR reaction, rather than EDL933 $h n s:: \mathrm{Kan}^{\mathrm{R}}$ genomic DNA. 


\section{4: Promoter activity of PecpR under acid stress}

To establish evidence of promoter activity with strains transfected with pMC1403-PecpR, strains of EDL933 carrying either the empty vector (pMC1403) or the

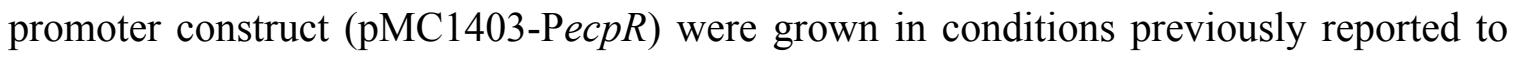
allow PecpR promoter activity and tested for promoter activity. Samples were grown overnight in LB at $37^{\circ} \mathrm{C}$ with shaking, followed by a 6 hour subculture in DMEM also at $37^{\circ} \mathrm{C}$ with shaking. These samples were analyzed for ecpR promoter activity via betagalactosidase activity assays (Figure 3.13).

To determine the impact of acid stress on ecpR promoter activity, EDL933 (pMC1403) and EDL933 (pMC1403-PecpR) underwent acid stress (AA30). Unstressed (UU30) controls of each were also processed. These samples were then analyzed for $e c p R$ promoter activity via beta-galactosidase activity assays (Figure 3.14, 3.16).

Additionally, to establish whether H-NS plays a role in modulating EcpA expression in response to acid stress, EDL933 hns:: $\operatorname{Kan}^{\mathrm{R}}$ (pMC1403) and EDL933 hns:: $\operatorname{Kan}^{\mathrm{R}}$ (pMC1403-PecpR) were also exposed to AA30 and UU30 conditions and assayed for promoter activity with beta-galactosidase activity assays (Figure 3.15, 3.16). 


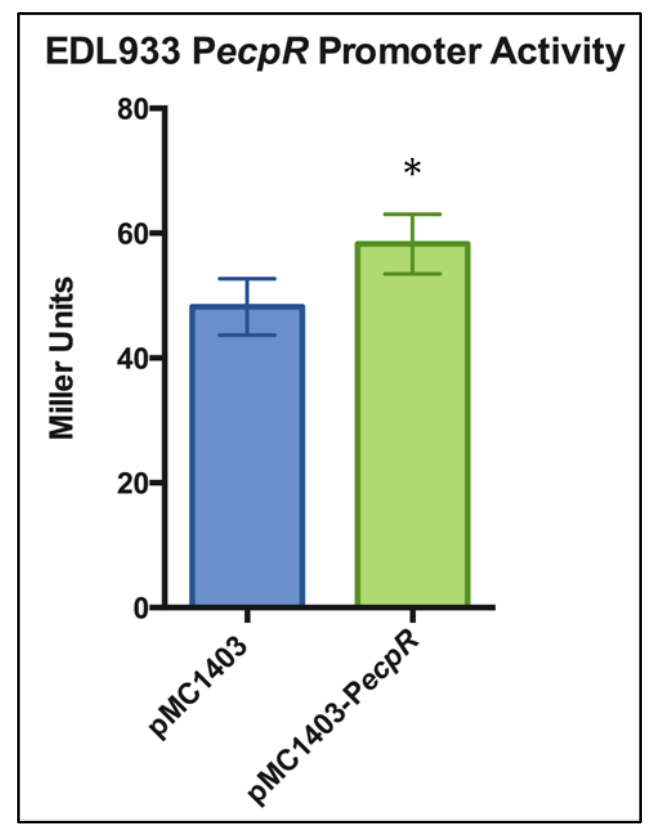

Figure 3.13: Confirmation of pMC1403-PecpR activity. Promoter activity in EDL933 (pMC1403) and EDL933 (pMC1403-PecpR) was assessed under unstressed conditions previously reported to demonstrate PecpR activity, samples were cultured overnight in LB with shaking at $37^{\circ} \mathrm{C}$, then subcultured for 6 hours in DMEM with shaking at $37^{\circ} \mathrm{C}$. This was done in order to confirm that the promoter construct is functioning as expected. Significant differences $(\mathrm{P} \leq 0.05)$ were observed between the carrying the empty vector (pMC1403) and the strain carrying the promoter construct (pMC1403-PecpR). This 1.8 fold increase in beta-galactosidase activity is representative of two independent experiments. 


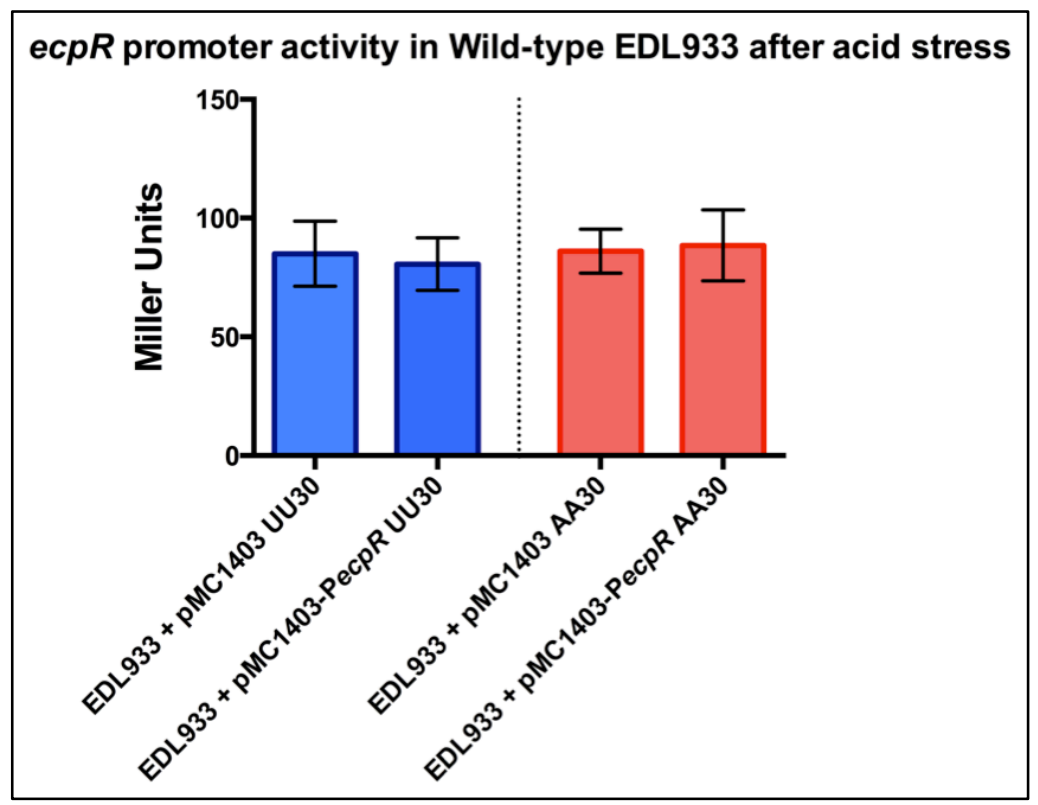

Figure 3.14: ecpR promoter activity in EDL933 after acid stress. Promoter activity in EDL933 (pMC1403) and EDL933 (pMC1403-PecpR) was assessed for both UU30 (unadapted, unstressed 30 mins) samples and AA30 (acid adapted, acid stressed 30 mins) samples. No significant differences $(\mathrm{P}>0.05)$ were observed between strains carrying the empty vector (pMC1403) and strains carrying the promoter construct (pMC1403-PecpR). $(\mathrm{N}=3, \mathrm{n}=9)$ 


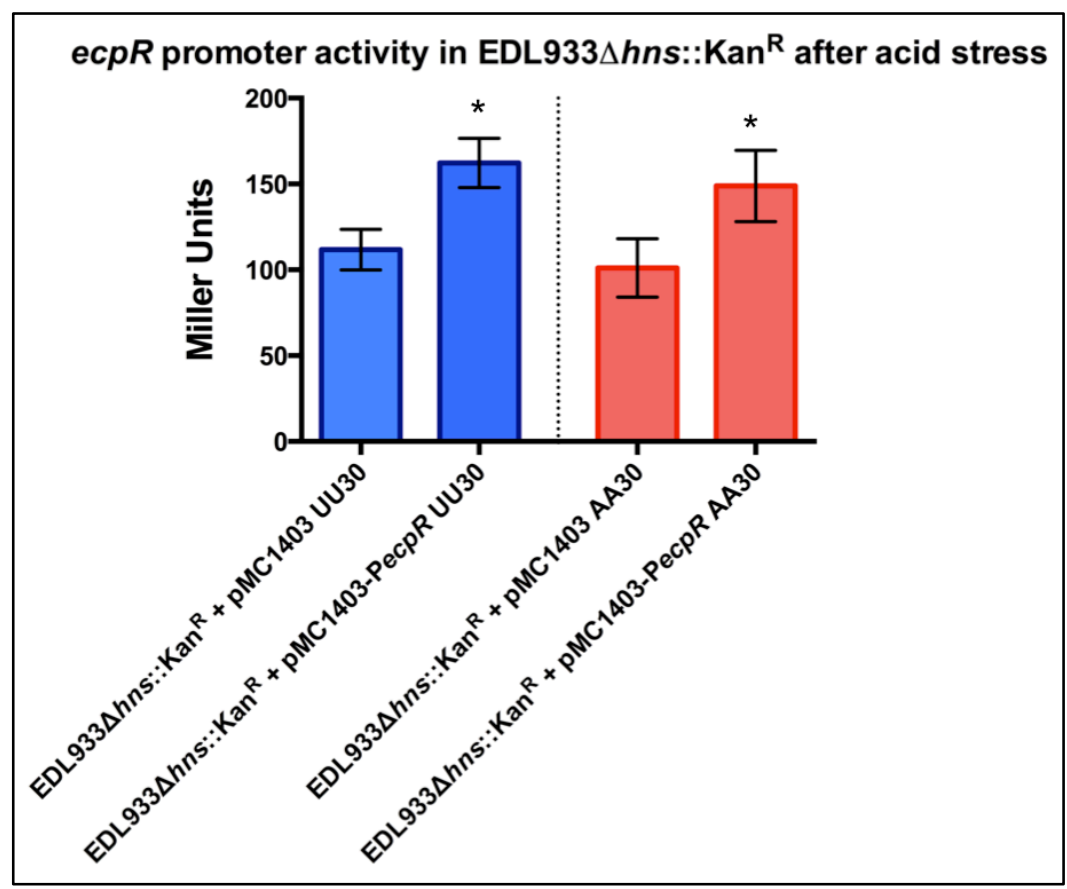

Figure 3.15: ecpR promoter activity in EDL933 hns:: $\operatorname{Kan}^{\mathrm{R}}$ after acid stress.

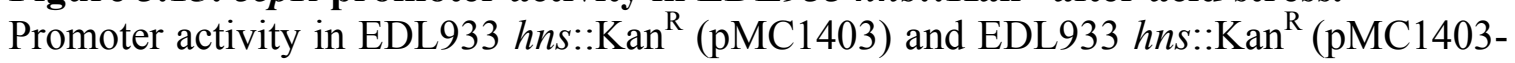
PecpR) was assessed for both UU30 (unadapted, unstressed 30 mins) samples and AA30 (acid adapted, acid stressed 30 mins) samples. Significant differences ( $* \mathrm{P} \leq 0.05)$ were observed between strains carrying the empty vector (pMC1403) and strains carrying the promoter construct (pMC1403-PecpR). $(\mathrm{N}=3, \mathrm{n}=9)$ 


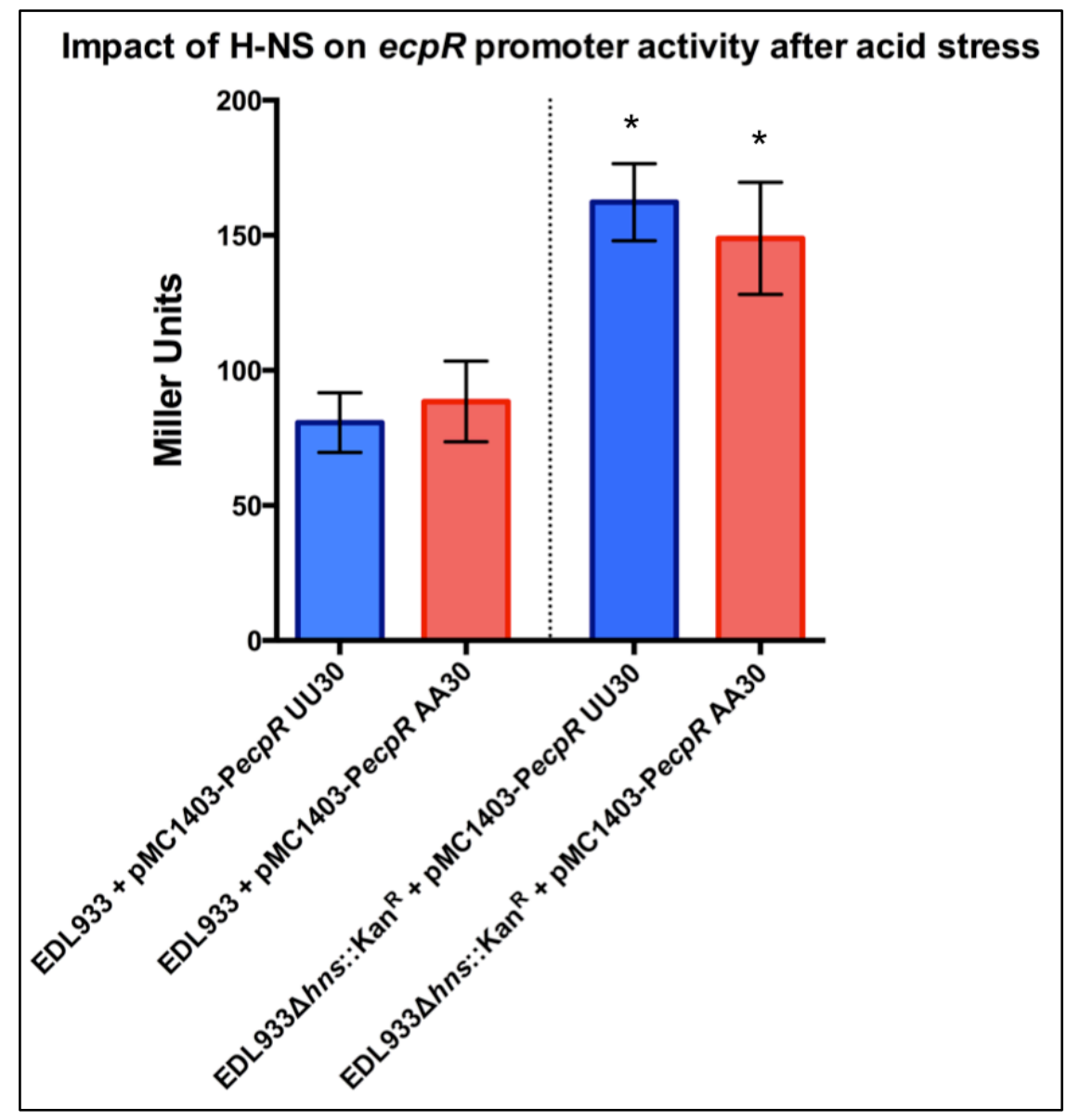

Figure 3.16: Effect of H-NS on ecpR promoter activity in EDL933 acid stress. Promoter activity in EDL933 (pMC1403-PecpR) and EDL933 hns::Kan ${ }^{\mathrm{R}}$ (pMC1403PecpR) was assessed for both UU30 (unadapted, unstressed 30 mins) samples and AA30 (acid adapted, acid stressed 30 mins) samples. Significant differences $(\mathrm{P} \leq 0.05)$ were observed between EDL933 and EDL933 hns::Kan ${ }^{\mathrm{R}}$ samples for both UU30 and AA30 samples. No significant differences $(* \mathrm{P}>0.05)$ were observed between UU30 treated samples and AA30 samples.

$(\mathrm{N}=3, \mathrm{n}=9)$ 


\section{Discussion}

The human body has in place many lines of defense against enteric pathogens. Among these are acute acid exposure in the stomach, and SCFA exposure in the large intestine. Enterohaemorrhagic E. coli $\mathrm{O} 157: \mathrm{H} 7$ is an enteric pathogen, with major health implications for humans, that has adapted to survive those defenses. In fact, rather than succumb to those gastrointestinal stresses, this pathogen has evolved to be able to use the stresses as signals of location within a host, allowing for successful colonization and infection. In a DNA microarray analysis of gene expression in O157:H7 it was shown that many genes related to virulence and adhesion were upregulated after acid stress ${ }^{31}$. Among the many genes to be affected was ecpA, the major subunit of the E. coli common pilus. This structure was also demonstrated to be an important adhesion factor for EHEC; a mutant strain lacking eсpA showed a significant decrease in adhesion to epithelial cells $^{27,57}$. This phenotype, a decrease in adhesion, was also observed in EHEC that had been exposed to either acid or SCFA stress conditions ${ }^{27}$.

While previous studies have suggested a link between acid or SCFA stress and expression levels of EcpA, the exact mechanisms of regulation for EcpA under those conditions is not fully understood. Two other research groups have determined that the ECP operon is under negative regulation by H-NS, a global regulator; and that it was under positive regulation by EcpR, encoded in the first gene of the operon ${ }^{43,47}$. Additionally, it was suggested through a personal communication that the mRNA for eсpA is a target for a global post-transcriptional regulator, CsrA. CsrA is known to be inhibited through activation of upstream pathways by exposure to SCFAs ${ }^{12}$. This led to the formation of the hypothesis that EcpA expression is modulated on both a transcriptional and translational level by different regulatory mechanisms. Under acid stress, it was hypothesized that decreases in H-NS would allow for an increase in ecpR promoter activity, and in turn, transcription of ecpA. Under SCFA stress, it was hypothesized that inhibition of CsrA would allow for an increase in translation of ecpA mRNAs. Both scenarios would provide an explanation for the previous results which indicated an upregulation of ecpA mRNA after acid stress, and an increase in ECP- 
mediated adhesion, potentially due to an increase in levels of ECP and thus EcpA, after either acid or SCFA stress.

Isogenic mutants of EDL933 lacking either hns or $u v r Y$ were constructed so that regulatory mechanisms for changes in ecpA expression could be elucidated. Both H-NS and UvrY are already known to regulate expression of other genes, and in fact, it was previously demonstrated that $\mathrm{H}-\mathrm{NS}$ regulates the $e c p$ operon, however neither has been directly implicated in regulation of ecpA in response to acid or SCFA stress. $\lambda$-red recombinase-mediated homologous recombination was employed to switch out the chromosomal target gene for a kanamycin resistance cassette. In addition, a mutant lacking the study's gene of interest, есрA, was constructed as a negative control when analyzing protein expression levels. Primers were designed to amplify a kanamycin resistance cassette, and included regions of homology just outside of the target gene. This allowed EHEC already expressing $\lambda$-red recombinase via pKD46 to undergo homologous recombination. Replacement of target genes was confirmed with both colony PCR (Figure 3.1, 3.2, 3.3) and sequence alignment (Figure 3.4, 3.5, 3.6). The confirmed mutants were used to characterize ecpA expression and regulation in both Western blots and beta-galactosidase activity assays.

Western blots using $\alpha$-EcpA antibodies demonstrated that ECP expression is under very specific environmental control (Figure 3.7, 3.8, 3.9), a result that is consistent when reviewing other bodies of research involving Western blot detection of EcpA (Table 4.1). In this study, no expression of EcpA was detected in samples of EDL933 grown in $\mathrm{LB}$, nor in samples grown at $37^{\circ} \mathrm{C}$ without $\mathrm{CO}_{2}$ supplementation. Exposure to acid stress (AA30 conditions) or SCFA stress $(90 \mathrm{mM} \mathrm{mix}$ ) did not appear to impact EcpA expression, despite previously reported microarray or adhesion assay results that would suggest otherwise. 
Table 4.1: Impact of strain and culture conditions on EcpA expression by Western blot

\begin{tabular}{|c|c|c|c|c|c|c|}
\hline \multirow[b]{2}{*}{ Strain } & \multicolumn{4}{|c|}{ Overnight conditions } & \multirow[b]{2}{*}{ Band Intensity } & \multirow[b]{2}{*}{ Reference } \\
\hline & Temp. & Media & Shaking? & Environment & & \\
\hline EHEC O157:H7 EDL933 & $37^{\circ} \mathrm{C}$ & DMEM & yes & $\mathrm{O}_{2}$ & + & \multirow{14}{*}{ Rendón et al., 2007 (58) } \\
\hline EHEC O157:H7 EDL933 & $37^{\circ} \mathrm{C}$ & DMEM & no & $5 \% \mathrm{CO}_{2}$ & ++ & \\
\hline EHEC 0157:H7 EDL933 & $37^{\circ} \mathrm{C}$ & DMEM & no & anaerobic & + & \\
\hline EHEC O157:H7 EDL933 & $37^{\circ} \mathrm{C}$ & LB & yes & $\mathrm{O}_{2}$ & 0 & \\
\hline EHEC O157:H7 EDL933 & $37^{\circ} \mathrm{C}$ & LB & no & $5 \% \mathrm{CO}_{2}$ & 0 & \\
\hline EHEC 0157:H7 EDL933 & $37^{\circ} \mathrm{C}$ & LB & no & anaerobic & 0 & \\
\hline EHEC O157:H7 EDL933 & $20^{\circ} \mathrm{C}$ & DMEM & yes & $\mathrm{O}_{2}$ & ++ & \\
\hline EHEC O157:H7 EDL933 & $20^{\circ} \mathrm{C}$ & DMEM & no & $5 \% \mathrm{CO}_{2}$ & +++ & \\
\hline EHEC 0157:H7 EDL933 & $20^{\circ} \mathrm{C}$ & DMEM & no & anaerobic & ++ & \\
\hline EHEC O157:H7 EDL933 & $20^{\circ} \mathrm{C}$ & LB & yes & $\mathrm{O}_{2}$ & 0 & \\
\hline EHEC 0157:H7 EDL933 & $20^{\circ} \mathrm{C}$ & LB & no & $5 \% \mathrm{CO}_{2}$ & 0 & \\
\hline EHEC 0157:H7 EDL933 & $20^{\circ} \mathrm{C}$ & LB & no & anaerobic & 0 & \\
\hline EHEC O157:H7 EDL933 & $26^{\circ} \mathrm{C}$ & DMEM & no & $\mathrm{O}_{2}$ & + & \\
\hline EHEC O157:H7 86-24 & $26^{\circ} \mathrm{C}$ & DMEM & no & $\mathrm{O}_{2}$ & + & \\
\hline
\end{tabular}


Table 4.1: Impact of strain and culture conditions on EcpA expression by Western blot (continued)

\begin{tabular}{|c|c|c|c|c|c|c|c|}
\hline \multirow[b]{2}{*}{ Strain } & \multirow[b]{2}{*}{ Temp. } & \multicolumn{3}{|c|}{ Growth conditions } & \multirow[b]{2}{*}{ Growth Phase } & & \multirow[b]{2}{*}{ Reference } \\
\hline & & Media & Shaking? & Environment & & $\begin{array}{c}\text { Band } \\
\text { Intensity }\end{array}$ & \\
\hline NMEC O18ac:K1:H7 IHE 3034 & $37^{\circ} \mathrm{C}$ & DMEM & yes & $\mathrm{O}_{2}$ & Mid-logarithmic & 0 & \multirow{18}{*}{$\begin{array}{c}\text { Lehti et al., } \\
2013 \text { (43) }\end{array}$} \\
\hline NMEC O18ac:K1:H7 IHE 3034 & $37^{\circ} \mathrm{C}$ & DMEM & yes & $5 \% \mathrm{CO}_{2}$ & Mid-logarithmic & 0 & \\
\hline NMEC O18ac:K1:H7 IHE 3034 & $37^{\circ} \mathrm{C}$ & $\mathrm{LB}, \mathrm{pH} 7.1$ & yes & $\mathrm{O}_{2}$ & Mid-logarithmic & + & \\
\hline NMEC O18ac:K1:H7 IHE 3034 & $37^{\circ} \mathrm{C}$ & LB, pH 5.5 & yes & $\mathrm{O}_{2}$ & Mid-logarithmic & + & \\
\hline NMEC O18ac:K1:H7 IHE 3034 & $37^{\circ} \mathrm{C}$ & $\begin{array}{c}\mathrm{LB}+0.1 \mathrm{M} \text { acetate, } \\
\mathrm{pH} 7.1\end{array}$ & yes & $\mathrm{O}_{2}$ & Mid-logarithmic & ++ & \\
\hline NMEC O18ac:K1:H7 IHE 3034 & $37^{\circ} \mathrm{C}$ & DMEM & yes & $\mathrm{O}_{2}$ & Stationary & 0 & \\
\hline NMEC O18ac:K1:H7 IHE 3034 & $37^{\circ} \mathrm{C}$ & DMEM & yes & $5 \% \mathrm{CO}_{2}$ & Stationary & 0 & \\
\hline NMEC O18ac:K1:H7 IHE 3034 & $37^{\circ} \mathrm{C}$ & $\mathrm{LB}, \mathrm{pH} 7.1$ & yes & $\mathrm{O}_{2}$ & Stationary & 0 & \\
\hline NMEC O18ac:K1:H7 IHE 3034 & $37^{\circ} \mathrm{C}$ & LB, pH 5.5 & yes & $\mathrm{O}_{2}$ & Stationary & + & \\
\hline NMEC O18ac:K1:H7 IHE 3034 & $37^{\circ} \mathrm{C}$ & $\begin{array}{c}\mathrm{LB}+0.1 \mathrm{M} \text { acetate, } \\
\mathrm{pH} 7.1\end{array}$ & yes & $\mathrm{O}_{2}$ & Stationary & + & \\
\hline NMEC O18ac:K1:H7 IHE 3034 & $20^{\circ} \mathrm{C}$ & DMEM & yes & $\mathrm{O}_{2}$ & Mid-logarithmic & + & \\
\hline NMEC O18ac:K1:H7 IHE 3034 & $20^{\circ} \mathrm{C}$ & LB, $\mathrm{pH} 7.1$ & yes & $\mathrm{O}_{2}$ & Mid-logarithmic & ++ & \\
\hline NMEC O18ac:K1:H7 IHE 3034 & $20^{\circ} \mathrm{C}$ & LB, pH 5.5 & yes & $\mathrm{O}_{2}$ & Mid-logarithmic & +++ & \\
\hline NMEC O18ac:K1:H7 IHE 3034 & $20^{\circ} \mathrm{C}$ & $\begin{array}{c}\mathrm{LB}+0.1 \mathrm{M} \text { acetate, } \\
\mathrm{pH} 7.1\end{array}$ & yes & $\mathrm{O}_{2}$ & Mid-logarithmic & ++ & \\
\hline NMEC O18ac:K1:H7 IHE 3034 & $20^{\circ} \mathrm{C}$ & DMEM & yes & $\mathrm{O}_{2}$ & Stationary & + & \\
\hline NMEC O18ac:K1:H7 IHE 3034 & $20^{\circ} \mathrm{C}$ & LB, pH 7.1 & yes & $\mathrm{O}_{2}$ & Stationary & ++ & \\
\hline NMEC O18ac:K1:H7 IHE 3034 & $20^{\circ} \mathrm{C}$ & LB, pH 5.5 & yes & $\mathrm{O}_{2}$ & Stationary & +++ & \\
\hline NMEC O18ac:K1:H7 IHE 3034 & $20^{\circ} \mathrm{C}$ & $\begin{array}{c}\mathrm{LB}+0.1 \mathrm{M} \text { acetate, } \\
\mathrm{pH} 7.1\end{array}$ & yes & $\mathrm{O}_{2}$ & Stationary & ++ & \\
\hline
\end{tabular}


Table 4.1: Impact of strain and culture conditions on EcpA expression by Western blot (continued)

\begin{tabular}{|c|c|c|c|c|c|c|c|c|c|c|c|}
\hline \multirow[b]{2}{*}{ Strain } & \multicolumn{4}{|c|}{ Overnight conditions } & \multicolumn{5}{|c|}{ Subculture conditions } & & \\
\hline & Temp. & Media & Shaking? & Environment & Temp. & Media & Shaking? & Environment & Time & $\begin{array}{c}\text { Band } \\
\text { Intensity }\end{array}$ & \\
\hline $\begin{array}{l}\text { EHEC O157:H7 } \\
\text { EDL933 }\end{array}$ & $37^{\circ} \mathrm{C}$ & LB & yes & 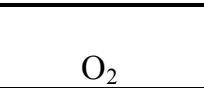 & $26^{\circ} \mathrm{C}$ & DMEM & no & $\mathrm{O}_{2}$ & NS* & + & \multirow{2}{*}{$\begin{array}{c}\text { Reference } \\
\text { Martínez- } \\
\text { Santos et } \\
\text { al., 2012 } \\
(47)\end{array}$} \\
\hline $\begin{array}{c}\text { EHEC O157:H7 } \\
\text { EDL933 hns::Kan }\end{array}$ & $37^{\circ} \mathrm{C}$ & LB & yes & $\mathrm{O}_{2}$ & $26^{\circ} \mathrm{C}$ & DMEM & no & $\mathrm{O}_{2}$ & NS & +++ & \\
\hline
\end{tabular}

\begin{tabular}{|c|c|c|c|c|c|c|c|c|c|c|c|}
\hline \multirow[b]{2}{*}{ Strain } & \multicolumn{4}{|c|}{ Overnight conditions } & \multicolumn{5}{|c|}{ Subculture conditions } & \multirow[b]{2}{*}{$\begin{array}{c}\text { Band } \\
\text { Intensity }\end{array}$} & \multirow[b]{2}{*}{ Reference } \\
\hline & Temp. & Media & Shaking? & Environment & Temp. & Media & Shaking? & Environment & Time & & \\
\hline $\begin{array}{l}\text { EHEC O157:H7 } \\
\text { EDL933 }\end{array}$ & $37^{\circ} \mathrm{C}$ & LB & yes & $\mathrm{O}_{2}$ & $26^{\circ} \mathrm{C}$ & DMEM & no & $\mathrm{O}_{2}$ & $\begin{array}{l}11 \\
\mathrm{hrs}\end{array}$ & + & \multirow{3}{*}{ This study } \\
\hline $\begin{array}{c}\text { EHEC O157:H7 } \\
\text { EDL933 uvr }:: \operatorname{Kan}^{\mathrm{R}}\end{array}$ & $37^{\circ} \mathrm{C}$ & LB & yes & $\mathrm{O} 2$ & $26^{\circ} \mathrm{C}$ & DMEM & no & $\mathrm{O}_{2}$ & $\begin{array}{l}11 \\
\text { hrs }\end{array}$ & 0 & \\
\hline $\begin{array}{c}\text { EHEC O157:H7 } \\
\text { EDL933 hns::Kan }\end{array}$ & $37^{\circ} \mathrm{C}$ & LB & yes & $\mathrm{O}_{2}$ & $26^{\circ} \mathrm{C}$ & DMEM & no & $\mathrm{O}_{2}$ & $\begin{array}{l}11 \\
\mathrm{hrs}\end{array}$ & +++ & \\
\hline
\end{tabular}

* NS: not specified 
There was preliminary evidence (Figure 3.9) that the BarA/UvrY two-component transduction system is indeed regulating expression of EcpA, potentially through inhibition of CsrA. Western blotting revealed that a sample of EDL933 uvrY::Kan ${ }^{\mathrm{R}}$, subcultured in DMEM statically for at $26^{\circ} \mathrm{C}$ for 11 hours had the same protein expression profile as EDL933 ecpA::Kan ${ }^{\mathrm{R}}$; both lacked a $21 \mathrm{kDa}$ band present in EDL933 and EDL933 hns::Kan ${ }^{\mathrm{R}}$, all samples were cultured in the same conditions. Previous researchers have demonstrated that BarA/UvrY is activated in E. coli grown in minimal media $^{35}$. BarA/UvrY upregulates transcription of two small non-coding RNAs, CsrB and CsrC, resulting in inhibition of global post-transcriptional regulator CrsA, and allowing for translation of CsrA's target mRNAs ${ }^{12,35,68}$. This result, while only indicative of a single replicate, suggests that in EHEC cultured in minimal media (DMEM) and lacking UvrY, translation of ecpA mRNA is inhibited, preventing expression of EcpA. While exposure to SCFAs at concentrations as low as $6 \mathrm{mM}$ have also been shown to activate BarA/UvrY, in this study no differences in expression of EcpA were observed between EDL933 and EDL933 uvrY::KanR samples exposed to a 90mM SCFA mix.

On the other hand, Western blots consistently revealed a strong band at $21 \mathrm{kDa}$, likely that of EcpA, in samples of EDL933 hns::Kan ${ }^{\mathrm{R}}$ probed with $\alpha$-EcpA (Figure 3.8). This was seen in a variety of culture conditions, including AA30 and UU30 conditions, 90mM SCFA stressed and unstressed control samples, unstressed DMEM subculture at $37^{\circ} \mathrm{C}$ with $5 \% \mathrm{CO}_{2}$, and unstressed DMEM subculture at $26^{\circ} \mathrm{C}$ without $\mathrm{CO}_{2}$. This result is consistent with previous research results indicating a role for H-NS as a negative regulator of the ecp operon ${ }^{43,47}$. Due to a lack of similar bands consistently present in EDL933 samples, it is difficult to conclude with certainty that the band observed is EcpA, but it is consistent with the absence of the band in EDL933 ecp $A: \mathrm{Kan}^{\mathrm{R}}$.

While H-NS is a negative regulator of ecpA, it does not appear to be directly regulating ecp $A$ directly in response to acid stress conditions. Promoter activity assays showed an increase in EDL933 hns::Kan ${ }^{\mathrm{R}}$ samples under both AA30 and UU30 conditions when compared to EDL933 samples of the same conditions. However there 
was no significant difference observed between AA30 and UU30 promoter activity levels in both EDL933 and EDL933 hns::Kan ${ }^{\mathrm{R}}$ (Figures 3.15, 3.16).

A recent publication by Lehti et al. investigated differential regulation of ECP/Mat fimbria in a broad range of $E$. coli isolates covering several phylogenetic groups $^{43}$. They observed that while there is extensive homology in ecp operon upstream regulatory regions, the conditions under which promoter activity was induced varied greatly ${ }^{43}$. They hypothesize that while there is a conserved regulatory mechanism that acts on the ecp operon, involving H-NS, IHF, and EcpR, that there are likely strainspecific transcription factors, under environmental control, that dictate the expression of the ecp operon ${ }^{43}$. The lack of difference in promoter activity in acid stressed versus control EHEC indicates that H-NS likely not the regulatory protein directly responsible for increases in ecpA mRNA levels under AA30 conditions previously observed with the DNA microarray, and that the EHEC-specific transcription factors involved remain unknown. It should also be noted that the microarray, while performed with samples from an EHEC O157:H7 strain, was not performed with EDL933, the primary strain used in this work. The use of a closely related but different strain, 86-24, could also be the cause of conflicting results between promoter activity observed in EDL933 AA30 samples and the increase in ecpA expression in 86-24 AA30 samples from the microarray, due to differences in strain-specific transcription factors regulating expression of the ecp operon.

The EHEC ecp operon promoter region used in this study, PecpR, was first reported by other researchers, Martinez-Santos et $\mathrm{al}^{47}$. In their search for an ecp operon transcriptional regulatory system they analyzed several regions upstream of the ecp operon via chloramphenicol acetyltransferase (CAT) resistance assays and found this region to contain both positive and negative regulatory elements ${ }^{47}$. In that study, the regions with promoter activity extended 198 bp downstream of the transcriptional start site (TSS), however during design of pMC1403-PecpR, used in this study, it was decided that altering the 3 ' end of the promoter region such that it only extended $120 \mathrm{bp}$ downstream of the TSS, to the end of the third codon of ecpR, would have no impact on 
promoter activity as all regulatory elements described by the previous research were still present in the region used (Figure 4.1). It was also assumed for this study that the use of a different reporter system for promoter activity, beta-galactosidase activity rather than CAT resistance, would be insignificant as both are well characterized systems for assessing promoter activity levels.

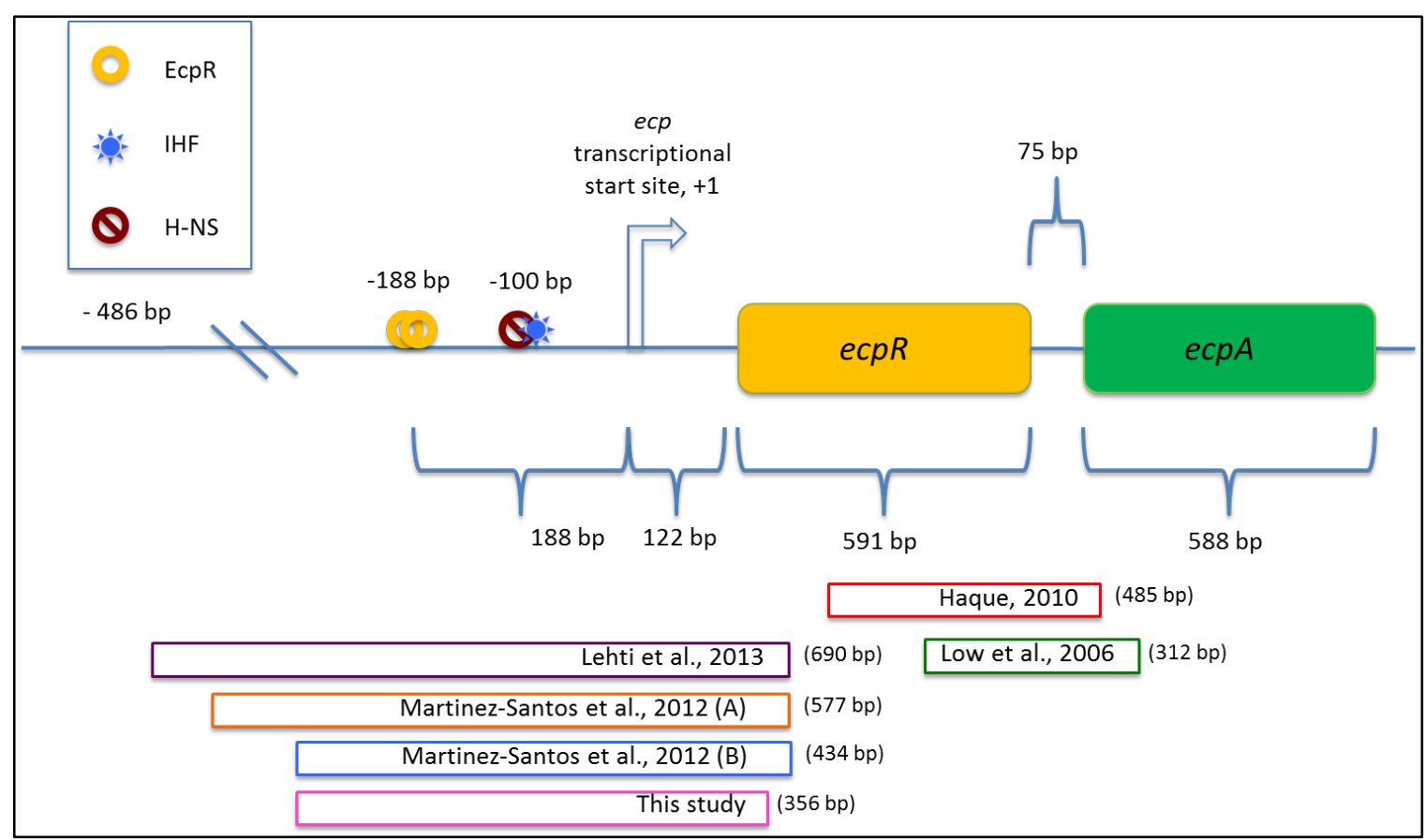

Figure 4.1: Comparison of ecp operon promoter regions used for ecp operon transcriptional analysis. Potential ecp operon promoter regions shown here were used in either CAT resistance assays or beta-galactosidase activity assays to determine $e c p$ transcription levels in different commensal E. coli, NMEC, or EHEC strains under various environmental conditions. See Table 4.2 for more detail. Image is not drawn to scale.

It was surprising then that in beta-galactosidase assays performed on samples of EDL933 grown in conditions reported in the previous study to induce ecp operon promoter activity did not yield high levels of beta-galactosidase activity. Rather the values obtained were close to values obtained with the empty reporter vector while a previously characterized positive control vector, pMC1403-PacrA, routinely provided very high levels of activity. Beta-galactosidase assays performed with EDL933 after AA30 treatment also showed low levels of promoter activity. Lehti et al, who looked at phylogenic differences in ecp operon and promoter regions, have also examined 
transcriptional regulation of the ecp operon in NMEC and K12 strains, through betagalactosidase activity assays ${ }^{43}$. Their findings indicate that the ecp operon regulatory region, which is highly conserved when compared to EHEC strains, extends farther upstream than initially believed, but that there is also a positive regulatory element found in the intergenic region between ecpR and ecpA. It is therefore likely that the region examined in this study was not the optimal region for analyzing ecp operon promoter activity; additionally it is possible that there are differences in the configuration and spacing of inserted promoter regions with regard to the reporter gene in different reporter systems. These issues could account for the lack of activity observed with an already established promoter region. 
Table 4.2: Impact of strain, culture conditions, and promoter region on ecp operon promoter activity

\begin{tabular}{|c|c|c|c|c|c|c|c|c|c|c|c|}
\hline & \multicolumn{5}{|c|}{ Growth conditions } & & & & \\
\hline Strain & $\begin{array}{c}\text { Promoter } \\
\text { region }\end{array}$ & $\begin{array}{c}\text { Reporter } \\
\text { system }\end{array}$ & Temp. & Media & Shaking? & Environment & Growth phase & Results & $\begin{array}{c}\text { Negative } \\
\text { control }\end{array}$ & $\begin{array}{c}\text { Negative } \\
\text { control } \\
\text { activity }\end{array}$ & Reference \\
\hline $\begin{array}{l}\text { EHEC } \\
\text { O157:H7 } \\
\text { ZAP193 }\end{array}$ & $\begin{array}{l}\text { Low et al., } \\
2006\end{array}$ & $\begin{array}{l}\text { Single copy } \\
\text { lacZ fusion }\end{array}$ & $37^{\circ} \mathrm{C}$ & LB & no & $\mathrm{O}_{2}$ & Exponential & 25 MU* & $\begin{array}{l}\text { wild-type } \\
\text { strain }\end{array}$ & $\begin{array}{l}\text { not } \\
\text { reported }\end{array}$ & \multirow[t]{11}{*}{$\begin{array}{c}\text { Low et al., } 2006 \\
\text { (46) }\end{array}$} \\
\hline $\begin{array}{l}\text { EHEC } \\
\text { O157:H7 } \\
\text { ZAP193 }\end{array}$ & $\begin{array}{l}\text { Low et al., } \\
2006\end{array}$ & $\begin{array}{l}\text { Single copy } \\
\text { lacZ fusion }\end{array}$ & $37^{\circ} \mathrm{C}$ & LB & no & $\mathrm{O}_{2}$ & Stationary & $\sim 20 \mathrm{MU}$ & $\begin{array}{l}\text { wild-type } \\
\text { strain }\end{array}$ & $\begin{array}{l}\text { not } \\
\text { reported }\end{array}$ & \\
\hline $\begin{array}{l}\text { EHEC } \\
\text { O157:H7 } \\
\text { ZAP193 }\end{array}$ & $\begin{array}{l}\text { Low et al., } \\
2006\end{array}$ & $\begin{array}{l}\text { Single copy } \\
\text { lacZ fusion }\end{array}$ & $37^{\circ} \mathrm{C}$ & LB & no & $\mathrm{O}_{2}$ & $\begin{array}{l}24 \mathrm{hr} \text { static } \\
\text { growth }\end{array}$ & $\sim 20 \mathrm{MU}$ & $\begin{array}{l}\text { wild-type } \\
\text { strain }\end{array}$ & $\begin{array}{l}\text { not } \\
\text { reported }\end{array}$ & \\
\hline $\begin{array}{l}\text { EHEC } \\
\text { O157:H7 } \\
\text { ZAP193 }\end{array}$ & $\begin{array}{l}\text { Low et al., } \\
2006\end{array}$ & $\begin{array}{l}\text { Single copy } \\
\text { lacZ fusion }\end{array}$ & $37^{\circ} \mathrm{C}$ & MEM & no & $\mathrm{O}_{2}$ & Exponential & $\sim 12 \mathrm{MU}$ & $\begin{array}{l}\text { wild-type } \\
\text { strain }\end{array}$ & $\begin{array}{l}\text { not } \\
\text { reported }\end{array}$ & \\
\hline $\begin{array}{l}\text { EHEC } \\
\text { O157:H7 } \\
\text { ZAP193 }\end{array}$ & $\begin{array}{l}\text { Low et al., } \\
2006\end{array}$ & $\begin{array}{l}\text { Single copy } \\
\text { lacZ fusion }\end{array}$ & $37^{\circ} \mathrm{C}$ & MEM & no & $\mathrm{O}_{2}$ & Stationary & $\sim 12 \mathrm{MU}$ & $\begin{array}{l}\text { wild-type } \\
\text { strain }\end{array}$ & $\begin{array}{l}\text { not } \\
\text { reported }\end{array}$ & \\
\hline $\begin{array}{l}\text { EHEC } \\
\text { O157:H7 } \\
\text { ZAP193 }\end{array}$ & $\begin{array}{l}\text { Low et al., } \\
2006\end{array}$ & $\begin{array}{l}\text { Single copy } \\
\text { lacZ fusion }\end{array}$ & $37^{\circ} \mathrm{C}$ & MEM & no & $\mathrm{O}_{2}$ & $\begin{array}{l}24 \mathrm{hr} \text { static } \\
\text { growth }\end{array}$ & $\sim 25 \mathrm{MU}$ & $\begin{array}{l}\text { wild-type } \\
\text { strain }\end{array}$ & $\begin{array}{l}\text { not } \\
\text { reported }\end{array}$ & \\
\hline $\begin{array}{l}\text { EHEC } \\
\text { O157:H7 } \\
\text { ZAP193 }\end{array}$ & $\begin{array}{l}\text { Low et al., } \\
2006\end{array}$ & $\begin{array}{l}\text { Single copy } \\
\text { lacZ fusion }\end{array}$ & $37^{\circ} \mathrm{C}$ & M9 & no & $\mathrm{O}_{2}$ & Exponential & $\sim 12 \mathrm{MU}$ & $\begin{array}{l}\text { wild-type } \\
\text { strain }\end{array}$ & $\begin{array}{l}\text { not } \\
\text { reported }\end{array}$ & \\
\hline $\begin{array}{l}\text { EHEC } \\
\text { O157:H7 } \\
\text { ZAP193 }\end{array}$ & $\begin{array}{l}\text { Low et al., } \\
2006\end{array}$ & $\begin{array}{l}\text { Single copy } \\
\text { lacZ fusion }\end{array}$ & $37^{\circ} \mathrm{C}$ & M9 & no & $\mathrm{O}_{2}$ & Stationary & $\sim 15 \mathrm{MU}$ & $\begin{array}{l}\text { wild-type } \\
\text { strain }\end{array}$ & $\begin{array}{l}\text { not } \\
\text { reported }\end{array}$ & \\
\hline $\begin{array}{l}\text { EHEC } \\
\text { O157:H7 } \\
\text { ZAP193 }\end{array}$ & $\begin{array}{l}\text { Low et al., } \\
2006\end{array}$ & $\begin{array}{l}\text { Single copy } \\
\text { lacZ fusion }\end{array}$ & $37^{\circ} \mathrm{C}$ & M9 & no & $\mathrm{O}_{2}$ & $\begin{array}{l}24 \mathrm{hr} \text { static } \\
\text { growth }\end{array}$ & $\sim 20 \mathrm{MU}$ & $\begin{array}{l}\text { wild-type } \\
\text { strain }\end{array}$ & $\begin{array}{l}\text { not } \\
\text { reported }\end{array}$ & \\
\hline $\begin{array}{l}\text { EHEC } \\
\text { O157:H7 } \\
\text { ZAP193 }\end{array}$ & $\begin{array}{l}\text { Low et al., } \\
2006\end{array}$ & $\begin{array}{l}\text { Single copy } \\
\text { lacZ fusion }\end{array}$ & $28^{\circ} \mathrm{C}$ & LB & no & $\mathrm{O}_{2}$ & Exponential & $\sim 20 \mathrm{MU}$ & $\begin{array}{l}\text { wild-type } \\
\text { strain }\end{array}$ & $\begin{array}{l}\text { not } \\
\text { reported }\end{array}$ & \\
\hline $\begin{array}{l}\text { EHEC } \\
\text { O157:H7 } \\
\text { ZAP193 }\end{array}$ & $\begin{array}{l}\text { Low et al., } \\
2006\end{array}$ & $\begin{array}{l}\text { Single copy } \\
\text { lacZ fusion }\end{array}$ & $28^{\circ} \mathrm{C}$ & LB & no & $\mathrm{O}_{2}$ & Stationary & $\sim 35 \mathrm{MU}$ & $\begin{array}{l}\text { wild-type } \\
\text { strain }\end{array}$ & $\begin{array}{l}\text { not } \\
\text { reported }\end{array}$ & \\
\hline
\end{tabular}




\begin{tabular}{|c|c|c|c|c|c|c|c|c|c|c|c|}
\hline $\begin{array}{l}\text { EHEC } \\
\text { O157:H7 } \\
\text { ZAP193 }\end{array}$ & $\begin{array}{l}\text { Low et al., } \\
2006\end{array}$ & $\begin{array}{l}\text { Single copy } \\
\text { lacZ fusion }\end{array}$ & $28^{\circ} \mathrm{C}$ & LB & no & $\mathrm{O}_{2}$ & $\begin{array}{l}24 \mathrm{hr} \text { static } \\
\text { growth }\end{array}$ & $\sim 45 \mathrm{MU}$ & $\begin{array}{l}\text { wild-type } \\
\text { strain }\end{array}$ & $\begin{array}{l}\text { not } \\
\text { reported }\end{array}$ & \\
\hline $\begin{array}{l}\text { EHEC } \\
\text { O157:H7 } \\
\text { ZAP193 }\end{array}$ & $\begin{array}{l}\text { Low et al., } \\
2006\end{array}$ & $\begin{array}{l}\text { Single copy } \\
\text { lacZ fusion }\end{array}$ & $34^{\circ} \mathrm{C}$ & LB & no & $\mathrm{O}_{2}$ & Exponential & $\sim 40 \mathrm{MU}$ & $\begin{array}{l}\text { wild-type } \\
\text { strain }\end{array}$ & $\begin{array}{l}\text { not } \\
\text { reported }\end{array}$ & \\
\hline $\begin{array}{l}\text { EHEC } \\
\text { O157:H7 } \\
\text { ZAP193 }\end{array}$ & $\begin{array}{l}\text { Low et al., } \\
2006\end{array}$ & $\begin{array}{l}\text { Single copy } \\
\text { lacZ fusion }\end{array}$ & $34^{\circ} \mathrm{C}$ & LB & no & $\mathrm{O}_{2}$ & Stationary & $\sim 25 \mathrm{MU}$ & $\begin{array}{l}\text { wild-type } \\
\text { strain }\end{array}$ & $\begin{array}{l}\text { not } \\
\text { reported }\end{array}$ & \\
\hline $\begin{array}{l}\text { EHEC } \\
\text { O157:H7 } \\
\text { ZAP193 }\end{array}$ & $\begin{array}{l}\text { Low et al., } \\
2006\end{array}$ & $\begin{array}{l}\text { Single copy } \\
\text { lacz fusion }\end{array}$ & $37^{\circ} \mathrm{C}$ & LB & no & $\mathrm{O}_{2}$ & Exponential & $\sim 25 \mathrm{MU}$ & $\begin{array}{l}\text { wild-type } \\
\text { strain }\end{array}$ & $\begin{array}{l}\text { not } \\
\text { reported }\end{array}$ & \\
\hline $\begin{array}{l}\text { EHEC } \\
\text { O157:H7 } \\
\text { ZAP193 }\end{array}$ & $\begin{array}{l}\text { Low et al., } \\
2006\end{array}$ & $\begin{array}{l}\text { Single copy } \\
\text { lacZ fusion }\end{array}$ & $37^{\circ} \mathrm{C}$ & LB & no & $\mathrm{O}_{2}$ & Stationary & $\sim 15 \mathrm{MU}$ & $\begin{array}{l}\text { wild-type } \\
\text { strain }\end{array}$ & $\begin{array}{l}\text { not } \\
\text { reported }\end{array}$ & \\
\hline $\begin{array}{l}\text { EHEC } \\
\text { O157:H7 } \\
\text { ZAP193 }\end{array}$ & $\begin{array}{l}\text { Low et al., } \\
2006\end{array}$ & $\begin{array}{l}\text { Single copy } \\
\text { lacz fusion }\end{array}$ & $37^{\circ} \mathrm{C}$ & LB & no & 02 & $\begin{array}{l}24 \mathrm{hr} \text { static } \\
\text { growth }\end{array}$ & $\sim 25 \mathrm{MU}$ & $\begin{array}{l}\text { wild-type } \\
\text { strain }\end{array}$ & $\begin{array}{l}\text { not } \\
\text { reported }\end{array}$ & \\
\hline $\begin{array}{l}\text { EHEC } \\
\text { O157:H7 } \\
\text { ZAP193 }\end{array}$ & $\begin{array}{l}\text { Low et al., } \\
2006\end{array}$ & $\begin{array}{l}\text { Single copy } \\
\text { lacZ fusion }\end{array}$ & $37^{\circ} \mathrm{C}$ & $\begin{array}{l}\text { Mcllvanines } \\
\text { Minimal Buffer, } \\
\mathrm{pH} 7\end{array}$ & no & $\mathrm{O}_{2}$ & NS** & $\sim 20 \mathrm{MU}$ & $\begin{array}{l}\text { wild-type } \\
\text { strain }\end{array}$ & $\begin{array}{l}\text { not } \\
\text { reported }\end{array}$ & \\
\hline $\begin{array}{l}\text { EHEC } \\
\text { O157:H7 } \\
\text { ZAP193 }\end{array}$ & $\begin{array}{l}\text { Low et al., } \\
2006\end{array}$ & $\begin{array}{l}\text { Single copy } \\
\text { lacZ fusion }\end{array}$ & $37^{\circ} \mathrm{C}$ & $\begin{array}{l}\text { Mcllvanines } \\
\text { Minimal Buffer, } \\
\text { pH } 5.2\end{array}$ & no & $\mathrm{O}_{2}$ & NS & $\sim 10 \mathrm{MU}$ & $\begin{array}{l}\text { wild-type } \\
\text { strain }\end{array}$ & $\begin{array}{l}\text { not } \\
\text { reported }\end{array}$ & \\
\hline $\begin{array}{l}\text { EHEC } \\
\text { O157:H7 } \\
\text { ZAP193 }\end{array}$ & $\begin{array}{l}\text { Low et al., } \\
2006\end{array}$ & $\begin{array}{l}\text { Single copy } \\
\text { lacZ fusion }\end{array}$ & $37^{\circ} \mathrm{C}$ & LB & no & Anaerobic & NS & $\sim 12 \mathrm{MU}$ & $\begin{array}{l}\text { wild-type } \\
\text { strain }\end{array}$ & $\begin{array}{l}\text { not } \\
\text { reported }\end{array}$ & \\
\hline $\begin{array}{l}\text { EHEC } \\
\text { O157:H7 } \\
\text { ZAP193 }\end{array}$ & $\begin{array}{l}\text { Low et al., } \\
2006\end{array}$ & $\begin{array}{l}\text { Single copy } \\
\text { lacZ fusion }\end{array}$ & $37^{\circ} \mathrm{C}$ & LB & yes & $\mathrm{O}_{2}$ & NS & $\sim 15 \mathrm{MU}$ & $\begin{array}{l}\text { wild-type } \\
\text { strain }\end{array}$ & $\begin{array}{l}\text { not } \\
\text { reported }\end{array}$ & \\
\hline
\end{tabular}

* MU: Miller Units

** NS: not specified 
Table 4.2: Impact of strain, culture conditions, and promoter region on ecp operon promoter activity (continued)

\begin{tabular}{|c|c|c|c|c|c|c|c|c|c|c|c|}
\hline & \multicolumn{4}{|c|}{ Overnight growth conditions } & & & & & \multirow[b]{2}{*}{ Reference } \\
\hline Strain & $\begin{array}{l}\text { Promoter } \\
\text { region }\end{array}$ & $\begin{array}{c}\text { Reporter } \\
\text { system }\end{array}$ & Temp. & Media & Shaking? & Environment & Treatment & Results & $\begin{array}{l}\text { Negative } \\
\text { control }\end{array}$ & $\begin{array}{c}\text { Negative } \\
\text { control } \\
\text { activity }\end{array}$ & \\
\hline $\begin{array}{l}\text { EHEC } \\
\text { O157:H7 } \\
86-24 \\
\end{array}$ & Haque, 2010 & $\begin{array}{l}\text { Promoter- } \\
\text { less lacz } \\
\text { vector, } \\
\text { pMC1403 }\end{array}$ & $37^{\circ} \mathrm{C}$ & LB & yes & $\mathrm{O}_{2}$ & AA30 & $\begin{array}{l}30.14 \\
\mathrm{MU}\end{array}$ & pMC1403 & $\begin{array}{l}\text { not } \\
\text { reported }\end{array}$ & \multirow{4}{*}{$\begin{array}{c}\text { Haque, } 2010 \\
\text { (27) }\end{array}$} \\
\hline $\begin{array}{l}\text { EHEC } \\
\text { O157:H7 } \\
86-24 \\
\end{array}$ & Haque, 2010 & $\begin{array}{l}\text { Promoter- } \\
\text { less lacz } \\
\text { vector, } \\
\text { pMC1403 }\end{array}$ & $37^{\circ} \mathrm{C}$ & LB & yes & $\mathrm{O}_{2}$ & UU30 & $\begin{array}{l}37.95 \\
\mathrm{MU}\end{array}$ & pMC1403 & $\begin{array}{l}\text { not } \\
\text { reported }\end{array}$ & \\
\hline $\begin{array}{l}\text { EHEC } \\
\text { O157:H7 } \\
86-24\end{array}$ & Haque, 2010 & $\begin{array}{l}\text { Promoter- } \\
\text { less lacz } \\
\text { vector, } \\
\text { pMC1403 }\end{array}$ & $37^{\circ} \mathrm{C}$ & $\begin{array}{l}\text { LB with } \\
\text { 90mM SCFA } \\
\text { mix }\end{array}$ & yes & $\mathrm{O}_{2}$ & $\begin{array}{l}\text { 90mM SCFA } \\
\text { stressed }\end{array}$ & $\begin{array}{l}7.08 \\
\mathrm{MU}\end{array}$ & pMC1403 & $\begin{array}{l}\text { not } \\
\text { reported }\end{array}$ & \\
\hline $\begin{array}{l}\text { EHEC } \\
\text { O157:H7 } \\
86-24 \\
\end{array}$ & Haque, 2010 & $\begin{array}{l}\text { Promoter- } \\
\text { less lacZ } \\
\text { vector, } \\
\text { pMC1403 }\end{array}$ & $37^{\circ} \mathrm{C}$ & LB & yes & $\mathrm{O}_{2}$ & $\begin{array}{l}\text { unstressed } \\
\text { control }\end{array}$ & $\begin{array}{l}23.91 \\
\mathrm{MU}\end{array}$ & pMC1403 & $\begin{array}{l}\text { not } \\
\text { reported }\end{array}$ & \\
\hline
\end{tabular}

\begin{tabular}{|c|c|c|c|c|c|c|c|c|c|c|c|c|c|c|c|}
\hline \multirow[b]{2}{*}{ Strain } & \multirow[b]{2}{*}{$\begin{array}{c}\text { Promoter } \\
\text { region }\end{array}$} & \multirow[b]{2}{*}{$\begin{array}{c}\text { Reporter } \\
\text { system }\end{array}$} & \multicolumn{4}{|c|}{ Overnight conditions } & \multicolumn{5}{|c|}{ Subculture conditions } & \multirow[b]{2}{*}{ Results } & \multirow[b]{2}{*}{$\begin{array}{c}\text { Negative } \\
\text { control }\end{array}$} & \multirow[b]{2}{*}{$\begin{array}{c}\text { Negative } \\
\text { control } \\
\text { activity }\end{array}$} & \multirow[b]{2}{*}{ Reference } \\
\hline & & & Temp. & Media & Shaking? & Environment & Temp. & Media & Shaking? & Environment & Time & & & & \\
\hline $\begin{array}{l}\text { EHEC } \\
\text { O157:H7 } \\
\text { EDL933 }\end{array}$ & $\begin{array}{l}\text { Martinez- } \\
\text { Santos et } \\
\text { al., } 2012 \\
\text { (A) }\end{array}$ & $\begin{array}{l}\text { Promoter- } \\
\text { less cat } \\
\text { vector, } \\
\text { pKK232-8 }\end{array}$ & $37^{\circ} \mathrm{C}$ & LB & yes & $\mathrm{O}_{2}$ & $37^{\circ} \mathrm{C}$ & DMEM & yes & $\mathrm{O}_{2}$ & $\begin{array}{l}6 \\
\text { hrs }\end{array}$ & $\begin{array}{l}225 \\
\text { umole/min/mg } \\
\text { CAT specific } \\
\text { activity }\end{array}$ & $\begin{array}{l}\text { pKK232- } \\
8\end{array}$ & $\begin{array}{l}\text { no activity } \\
\text { observed }\end{array}$ & \multirow{2}{*}{$\begin{array}{l}\text { Martinez- } \\
\text { Santos et } \\
\text { al., } 2012 \\
\text { (47) }\end{array}$} \\
\hline $\begin{array}{l}\text { EHEC } \\
\text { O157:H7 } \\
\text { EDL933 }\end{array}$ & $\begin{array}{l}\text { Martinez- } \\
\text { Santos et } \\
\text { al., } 2012 \\
\text { (B) }\end{array}$ & $\begin{array}{l}\text { Promoter- } \\
\text { less cat } \\
\text { vector, } \\
\text { pKK232-8 }\end{array}$ & $37^{\circ} \mathrm{C}$ & LB & yes & $\mathrm{O}_{2}$ & $37^{\circ} \mathrm{C}$ & DMEM & yes & $\mathrm{O}_{2}$ & $\begin{array}{l}6 \\
\text { hrs }\end{array}$ & $\begin{array}{l}\sim 225 \\
\text { umole/min/mg } \\
\text { CAT specific } \\
\text { activity }\end{array}$ & $\begin{array}{l}\text { pKK232- } \\
8\end{array}$ & $\begin{array}{l}\text { no activity } \\
\text { observed }\end{array}$ & \\
\hline
\end{tabular}


Table 4.2: Impact of strain, culture conditions, and promoter region on ecp operon promoter activity (continued)

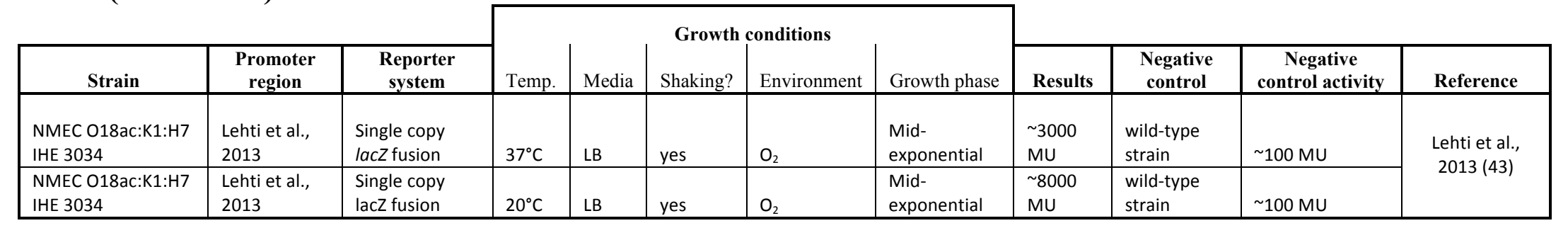

\begin{tabular}{|c|c|c|c|c|c|c|c|c|c|c|c|}
\hline \multirow[b]{2}{*}{ Strain } & \multirow[b]{2}{*}{$\begin{array}{c}\text { Promoter } \\
\text { region }\end{array}$} & \multirow[b]{2}{*}{ Reporter system } & \multicolumn{4}{|c|}{ Overnight growth conditions } & \multirow[b]{2}{*}{ Treatment } & \multirow[b]{2}{*}{ Results } & \multirow[b]{2}{*}{$\begin{array}{l}\text { Negative } \\
\text { control }\end{array}$} & \multirow[b]{2}{*}{$\begin{array}{c}\text { Negative } \\
\text { control } \\
\text { activity }\end{array}$} & \multirow[b]{2}{*}{ Reference } \\
\hline & & & Temp. & Media & Shaking? & Environment & & & & & \\
\hline $\begin{array}{l}\text { EHEC O157:H7 } \\
\text { EDL933 }\end{array}$ & This study & $\begin{array}{l}\text { Promoter-less lacZ } \\
\text { vector, pMC1403 }\end{array}$ & $37^{\circ} \mathrm{C}$ & LB & yes & $\mathrm{O}_{2}$ & AA30 & $\begin{array}{l}88.5 \\
\mathrm{MU}\end{array}$ & pMC1403 & $86.1 \mathrm{MU}$ & \multirow{5}{*}{ This study } \\
\hline $\begin{array}{l}\text { EHEC O157:H7 } \\
\text { EDL933 }\end{array}$ & This study & $\begin{array}{l}\text { Promoter-less lacZ } \\
\text { vector, pMC1403 }\end{array}$ & $37^{\circ} \mathrm{C}$ & LB & yes & $\mathrm{O}_{2}$ & UU30 & $\begin{array}{l}80.6 \\
\mathrm{MU}\end{array}$ & pMC1403 & $85.0 \mathrm{MU}$ & \\
\hline $\begin{array}{l}\text { EHEC 0157:H7 } \\
\text { EDL933 hns::Kan }\end{array}$ & This study & $\begin{array}{l}\text { Promoter-less lacZ } \\
\text { vector, pMC1403 }\end{array}$ & $37^{\circ} \mathrm{C}$ & LB & yes & $\mathrm{O}_{2}$ & AA30 & $\begin{array}{l}148.9 \\
\mathrm{MU}\end{array}$ & pMC1403 & $101.1 \mathrm{MU}$ & \\
\hline $\begin{array}{l}\text { EHEC 0157:H7 } \\
\text { EDL933 hns::Kan }\end{array}$ & This study & $\begin{array}{l}\text { Promoter-less lacZ } \\
\text { vector, pMC1403 }\end{array}$ & $37^{\circ} \mathrm{C}$ & LB & yes & $\mathrm{O}_{2}$ & UU30 & $\begin{array}{l}162.3 \\
\mathrm{MU}\end{array}$ & pMC1403 & $111.7 \mathrm{MU}$ & \\
\hline $\begin{array}{l}\text { EHEC 0157:H7 } \\
\text { EDL933 }\end{array}$ & This study & $\begin{array}{l}\text { Promoter-less lacZ } \\
\text { vector, pMC1403 }\end{array}$ & $37^{\circ} \mathrm{C}$ & LB & yes & $\mathrm{O}_{2}$ & $\begin{array}{l}6 \mathrm{hr} \text {. DMEM subculture( } \\
37^{\circ} \mathrm{C} \text {, with shaking, } \mathrm{O}_{2} \text { ) }\end{array}$ & $\begin{array}{l}58.3 \\
\mathrm{MU}\end{array}$ & pMC1403 & $48.2 \mathrm{MU}$ & \\
\hline
\end{tabular}


The ultimate goal of this work was to elucidate the regulatory mechanisms at work in ECP-mediated adhesion under acid or SCFA stress. Several approaches were attempted, but within the scope of this study, none were successful in discovering exactly what molecular mechanisms were responsible for increases in expression of EcpA specifically under physiologically relevant exposure to acute acid stress mimicking passage through the stomach, or SCFA stress experienced during colonization of the distal colon. This could have been due to several factors; prominently among them was a lack of strongly specific $\alpha$-EcpA antisera; the results observed varied greatly between experimental replicates. This led to inconclusive results with regard to EcpA production levels under acid or SCFA stress. Without western blot results that clearly indicate changes in EcpA production in the parental strain under acid or SCFA stress, it is in turn not possible to determine if the hypothesized regulators, H-NS and UvrY, are responsible for directly modulating expression of EcpA under acid or SCFA stress. Without baseline EcpA production levels from acid or SCFA stressed EDL933, no comparison was possible.

Overall, there still remains the potential of a regulatory protein in EHEC EDL933 modulating ecpA transcription under AA30 conditions; however it does not appear to be H-NS, a known ecp operon and global regulator. The link between SCFA activation of $\mathrm{BarA} / \mathrm{UvrY}$ and increased translation of ecpA mRNA via interaction with CsrA was not confirmed, but remains a viable possibility and is summarized, in cooperation with acid stress modulation of ecp A, in Figure 4.1.

ECP is known to be an important factor in EHEC adhesion to abiotic surfaces, to host epithelial cells, and to other bacterial cells, depending on their environment. Because EHEC is an enteric pathogen that colonizes the colon, it has in place survival strategies to withstand environmental stresses encountered in the human gastrointestinal tract such as acute acid and SCFA exposure. It is an exciting possibility then that EHEC have not only evolved to survive those stresses, but also to use them as cues to sense their location within a host organism and modulate gene expression accordingly. 


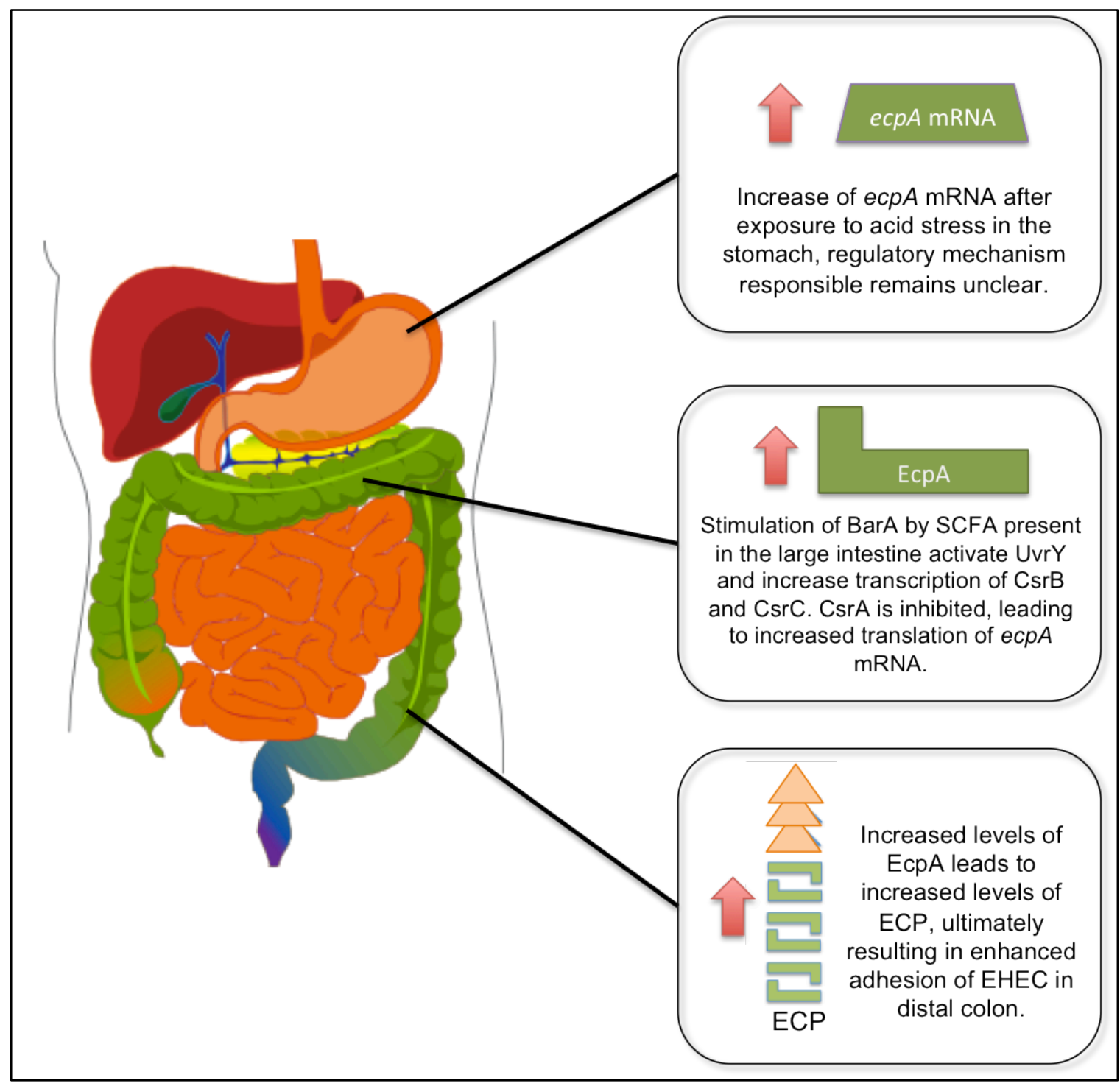

Figure 4.2: Potential mechanisms modulating ecpA expression in EHEC 0157:H7 under acid and SCFA stress. Previous results have indicated that ECP-mediated adhesion to epithelial cells, as well as ecpA transcription is enhanced in acid stressed (AA30) EHEC. Similar increases were seen with adhesion of SCFA (90mM) stressed EHEC to epithelial cells. Currently, the exact regulatory mechanisms that modulate ecp $A$ transcription during acid stress are unknown. It is hypothesized that exposure to SCFA in the large intestine results in an increase in translation of eсрA mRNA, leading to an increase in EcpA levels. Increased EcpA levels would provide an explanation for increased ECP-mediated adhesion in EHEC exposed to either acid or SCFA stress, as EcpA serves as the major pilin subunit of ECP. Human digestive system image obtained from http://stin-e-taxi.blogspot.ca/2011/12/15.html. 


\section{Future Work}

In order to successfully observe changes in the level of EcpA expression under acid or SCFA stress, it would be advantageous to add an epitope tag such as green fluorescent protein (GFP) to ecpA in the genome of EDL933. Such a tag would allow for specific probing of EcpA with commercial $\alpha$-GFP antibodies,

In addition to GFP tagging EcpA, a double mutant strain lacking both hns and eсpA could be created. This strain could be used to verify that the strong band present in EDL933 hns::Kan ${ }^{\mathrm{R}}$ samples on Western blots is in fact EcpA as is currently suspected.

The current study was unable to demonstrate direct effects of H-NS or UvrY in regulation of EcpA under acid or SCFA stress conditions, so it would also be interesting to determine if the regulatory mutants demonstrate changes in adhesion levels to cultured epithelial cells under those stresses. Incorporation of a GFP tag could prove to be useful in this application as well; regulatory mutants could be tagged and fluorescent microscopy used to quantify adherent bacteria expressing EcpA.

It is also understood that in the course of human infection, acid stress and SCFA do not occur in isolation. The bacteria will first encounter acute acid stress in the stomach, and will eventually colonize in the colon in the presence of SCFAs. As discussed previously, there are both transcriptional and translational regulatory systems hypothesized to be involved in ecpA/EcpA expression; transcriptional regulation was hypothesized to be in response to acid stress while translational regulation is in responsive to SCFA stress. Exposing EHEC to these two stresses in succession could potentially result in an even higher level of adhesion or EcpA expression than either stress has previously demonstrated individually. This could be explored on an mRNA level with reverse transcriptase real-time PCR.

And lastly, ECP is a structure that is employed by commensal and pathogenic $E$. coli strains such as EHEC. The use of a common structure for adhesion is a strategy that 
might allow EHEC to adhere to host cells without immediately initiating an immune response. Perhaps EHEC are able to sense the presence of commensal E. coli in the colon, leading to a preferential use of ECP for adhesion. The impact of co-incubation of commensal E. coli with EHEC, separated only by a filter, on ECP-mediated adhesion or EcpA expression levels, could provide insight on the importance of commensal bacteria in EHEC pathogenesis. 
6. Appendix A: Supplementary Data 


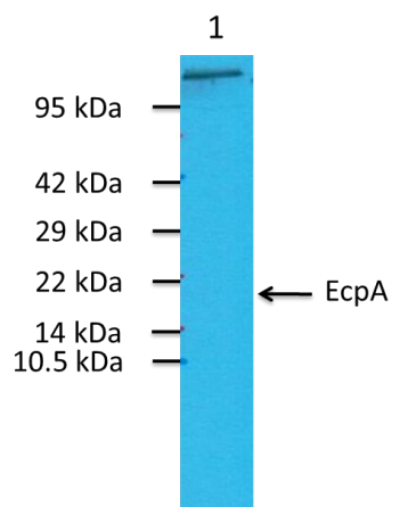

Overnight Growth Conditions: DMEM; $28^{\circ} \mathrm{C}$ static, no $\mathrm{CO}_{2}$ Subculture Conditions: $\mathrm{n} / \mathrm{a}$

Sample Preparation: boiled in Laemelli buffer

SDS-PAGE: 15\% PAGE; 130V, 90 minutes

Transfer: $100 \mathrm{~V} ; 60$ minutes at room temperature

Blocking: TBST with 5\% non-fat milk; 60 mins @ RT

$1^{\circ}$ Antibody: Batch $1 \alpha$-EcpA (1:3000 in TBST with 5\% non-fat milk); overnight at $4^{\circ} \mathrm{C}$

$2^{\circ}$ Antibody: HRP conjugated goat-anti-rabbit (1:10,000 in TBST);60 mins @, RT

Figure S1 Lane contents are as follows: $1-86-24(25 \mathrm{uL})$

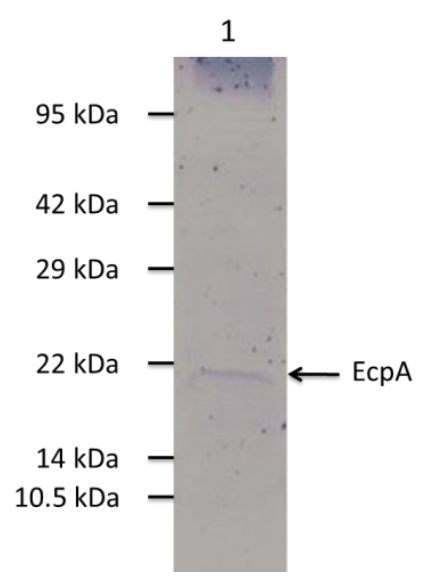

Overnight Growth Conditions: DMEM; $30^{\circ} \mathrm{C}$ static, no $\mathrm{CO}_{2}$

Subculture Conditions: $n / a$

Sample Preparation: boiled in water $\mathrm{pH} 1.5$, then boiled in Laemelli buffer

SDS-PAGE: 15\% PAGE; 130V, 90 minutes

Transfer: $100 \mathrm{~V} ; 60$ minutes at room temperature

Blocking: TBST with 5\% non-fat milk; 60 minutes at room temperature

$1^{\circ}$ Antibody: Batch $1 \alpha$-EcpA (1:2000 in TBST with 5\% non-fat milk); 60

minutes at room temperature then overnight at $4{ }^{\circ} \mathrm{C}$

$2^{\circ}$ Antibody: Alkaline phosphatase conjugated goat-anti-rabbit (1:30,000 in

TBST); 60 minutes at room temperature

Figure S2 Lane contents are as follows: $1-86-24(25 \mathrm{uL})$

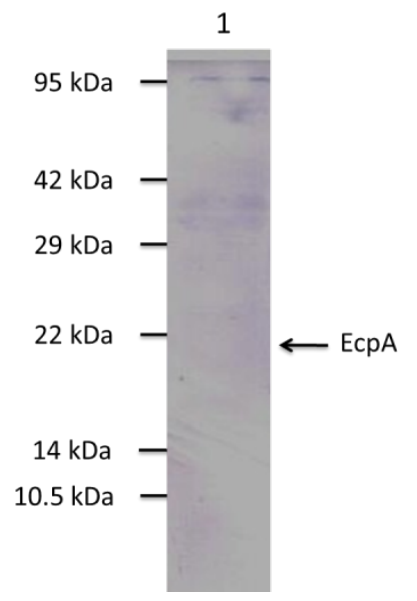

Overnight Growth Conditions: $\mathrm{LB} ; 37^{\circ} \mathrm{C}$ with shaking, no $\mathrm{CO}_{2}$

Subculture Conditions: $\mathrm{n} / \mathrm{a}$

Sample Preparation: boiled in water pH1.5, then boiled in Laemelli buffer

SDS-PAGE: $15 \%$ PAGE; 130V, 90 minutes

Transfer: $100 \mathrm{~V} ; 60$ minutes at room temperature

Blocking: TBST with 5\% non-fat milk; 60 minutes at room temperature

$1^{\circ}$ Antibody: Batch $1 \alpha$-EcpA (1:2000 in TBST with 5\% non-fat milk); 60 minutes at room temperature then overnight at $4^{\circ} \mathrm{C}$

$2^{\circ}$ Antibody: Alkaline phosphatase conjugated goat-anti-rabbit $(1: 30,000$ in TBST); 60 mins @ RT

Figure S3 Lane contents are as follows: $1-86-24$ (6.65uL, 30ug total protein) 


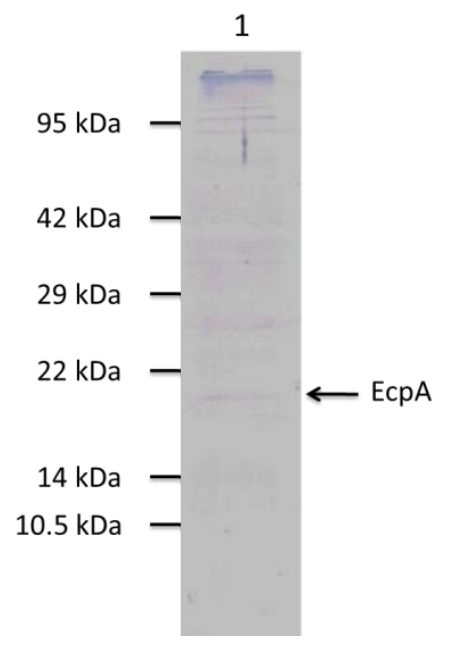

Figure S4 Lane contents are as follows: 1 - 86-24 (20uL, 80ug total protein)

Overnight Growth Conditions: DMEM; $30^{\circ} \mathrm{C}$ static, no $\mathrm{CO}_{2}$ Subculture Conditions: $\mathrm{n} / \mathrm{a}$

Sample Preparation: boiled in water $\mathrm{pH} 1.5$, then boiled in Laemelli buffer SDS-PAGE: $15 \%$ PAGE; 130V, 90 minutes

Transfer: $100 \mathrm{~V} ; 60$ minutes at room temperature

Blocking: TBST with 5\% non-fat milk; 60 minutes at room temperature $1^{\circ}$ Antibody: Batch $1 \alpha$-EcpA (1:2000 in TBST with 5\% non-fat milk); 60 minutes at room temperature then overnight at $4{ }^{\circ} \mathrm{C}$

$2^{\circ}$ Antibody: Alkaline phosphatase conjugated goat-anti-rabbit (1:30,000 in TBST);60 mins@RT

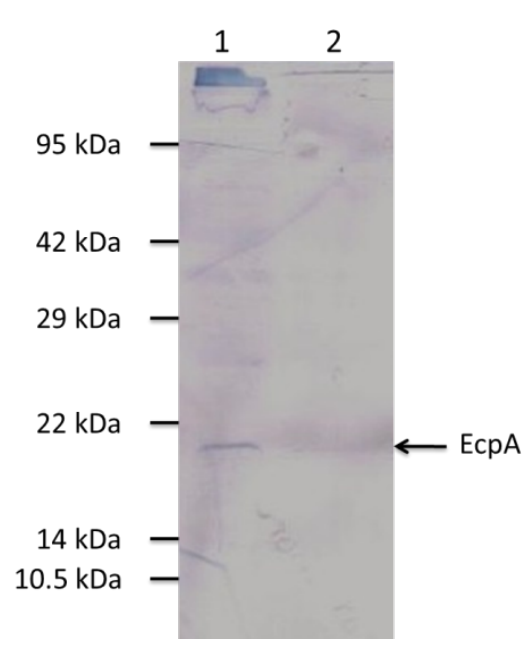

Figure S5 Lane contents are as follows: 1 - 86-24, UU30 (13uL, 80ug total protein) $2-86-24$, AA30 (18.5uL, 80ug total protein)

Overnight Growth Conditions: $\mathrm{LB} ; 37^{\circ} \mathrm{C}$ with shaking, no $\mathrm{CO}_{2}$

Subculture Conditions: AA30 or UU30

Sample Preparation: boiled in water $\mathrm{pH} 1.5$, then boiled in Laemelli buffer SDS-PAGE: 15\% PAGE; 130V, 90 minutes

Transfer: $110 \mathrm{~V} ; 60$ minutes at room temperature

Blocking: TBST with $5 \%$ non-fat milk; overnight at $4^{\circ} \mathrm{C}$

$1^{\circ}$ Antibody: Batch $1 \alpha$-EcpA (1:2000 in TBST with 5\% non-fat milk); 60 minutes at room temperature then overnight at $4^{\circ} \mathrm{C}$

$2^{\circ}$ Antibody: Alkaline phosphatase conjugated goat-anti-rabbit $(1: 30,000$ in TBST);60 mins@RT 


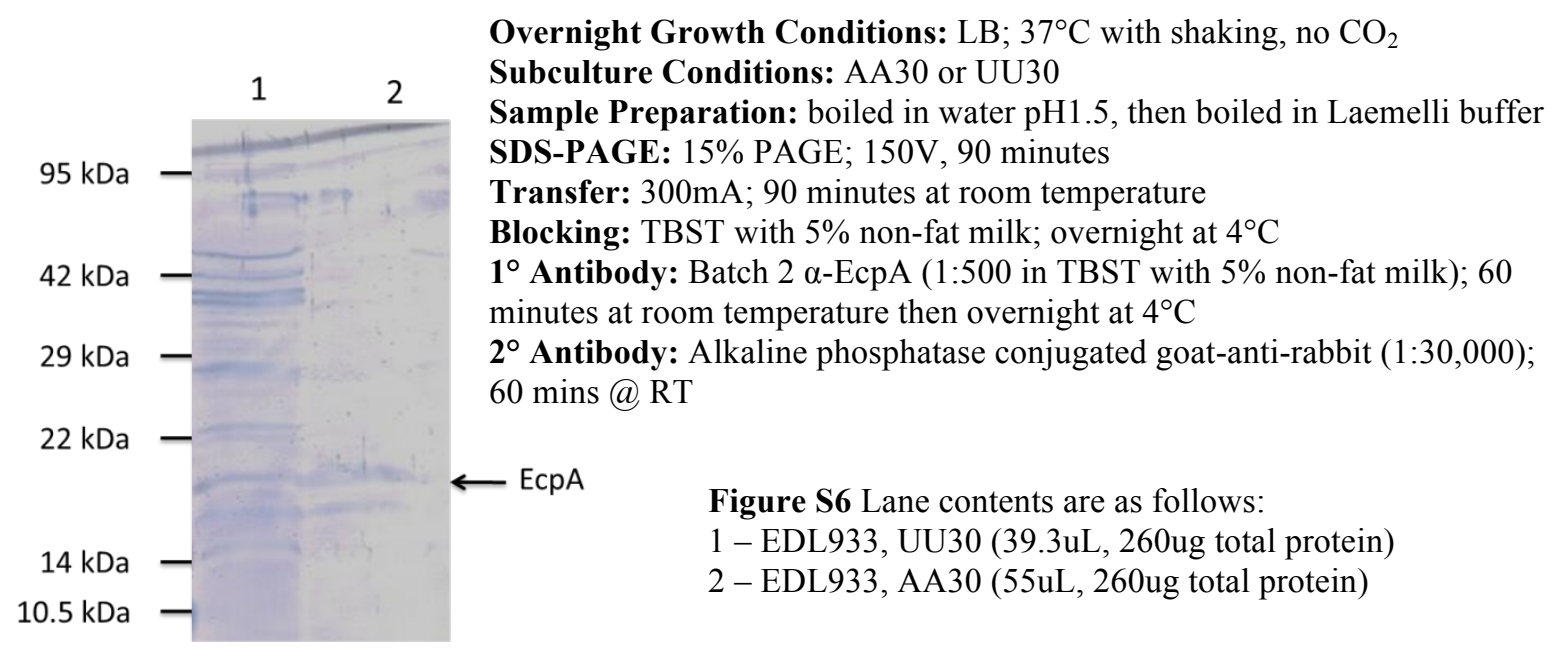

Overnight Growth Conditions: LB with or without $90 \mathrm{mM} \mathrm{SCFA} ; 37^{\circ} \mathrm{C}$ with shaking, no $\mathrm{CO}_{2}$

Subculture Conditions: 90mM SCFA stressed or unstressed control Sample Preparation: boiled in water $\mathrm{pH} 1.5$, then boiled in Laemelli buffer

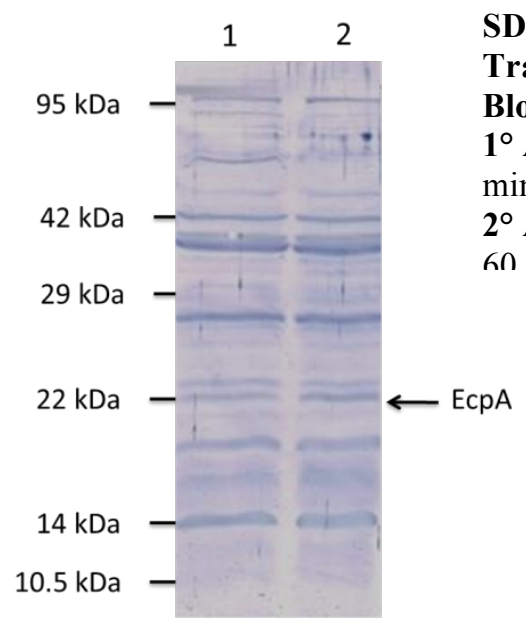

Figure S7 Lane contents are as follows:

1 - EDL933, unstressed control (25uL, 68ug total protein)

2 - EDL933, 90mM SCFA stressed (55uL, 68ug total protein) 


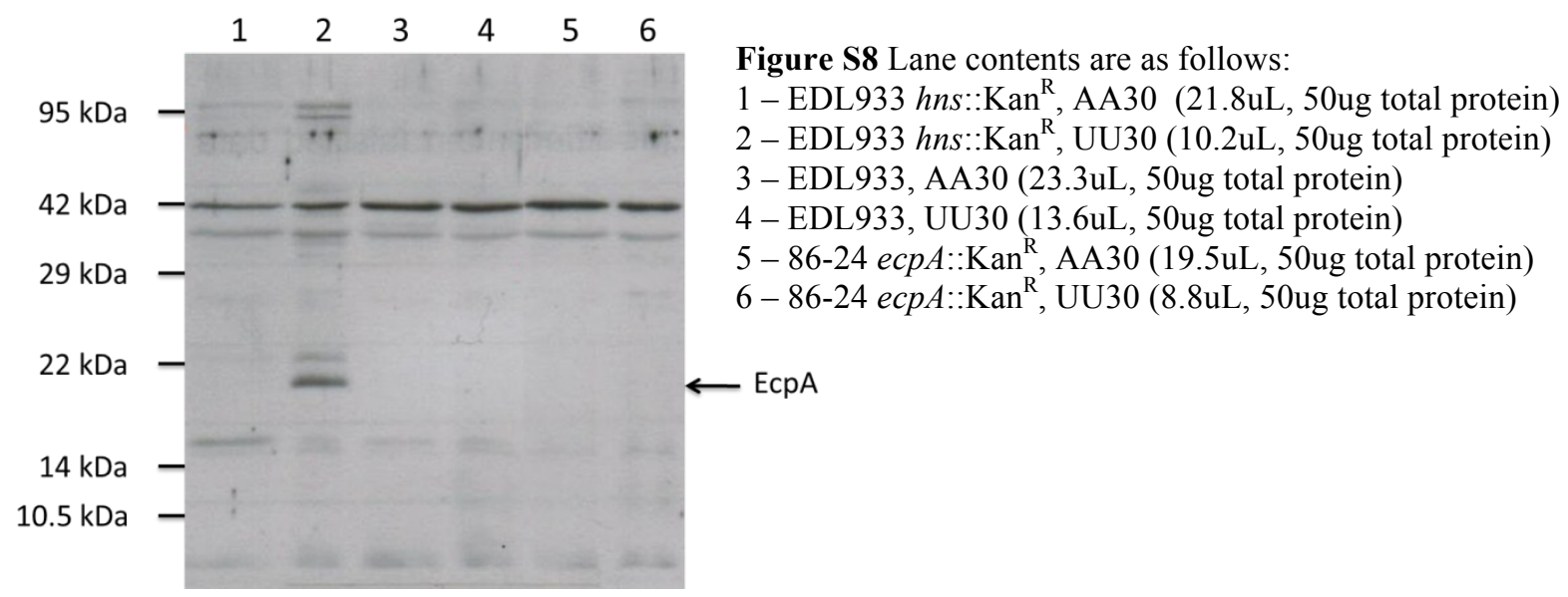

Overnight Growth Conditions: $\mathrm{LB} ; 37^{\circ} \mathrm{C}$ with shaking, no $\mathrm{CO}_{2}$

Subculture Conditions: AA30 or UU30

Sample Preparation: boiled in water $\mathrm{pH} 1.5$, then boiled in Laemelli buffer SDS-PAGE: $15 \%$ PAGE; 130V, 90 minutes

Transfer: $100 \mathrm{~V} ; 60$ minutes at room temperature

Blocking: TBST with $5 \%$ non-fat milk; overnight at $4{ }^{\circ} \mathrm{C}$

$1^{\circ}$ Antibody: Batch $2 \alpha$-EcpA (1:500 in TBST with 5\% non-fat milk); 60 minutes at room temperature then overnight at $4{ }^{\circ} \mathrm{C}$

$2^{\circ}$ Antibody: Horseradish peroxidase conjugated goat-anti-rabbit (1:10,000);

60 mins@RT

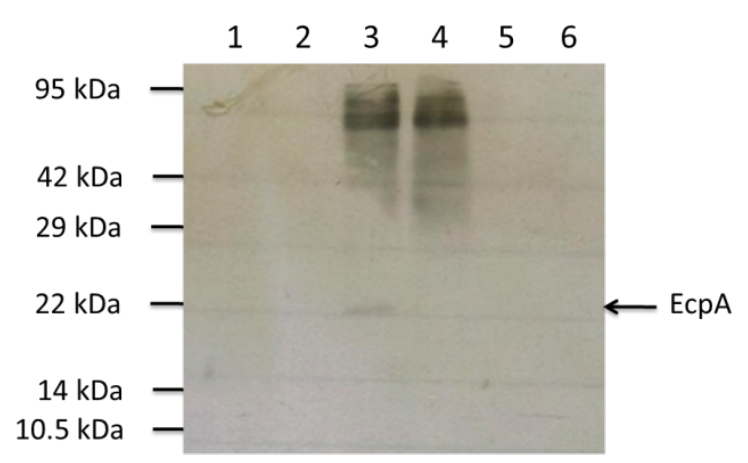

Figure S9 Lane contents are as follows: 1 - EDL933, UU30 (55uL, 70ug total protein)

2 - EDL933, AA30 (55uL, 70ug total protein)

3 - EDL933 hns::Kan ${ }^{\mathrm{R}}$, UU30 (55uL, 70ug total protein)

4 - EDL933 $h n s:: \operatorname{Kan}^{\mathrm{R}}$, AA30 (55uL, 70ug total protein)

5 - EDL933 ecpA::Kan ${ }^{\mathrm{R}}$, UU30 (55uL, 70ug total protein)

6 - EDL933 ecpA::Kan ${ }^{\mathrm{R}}$, AA30 (55uL, 70ug total protein)

Overnight Growth Conditions: $\mathrm{LB} ; 37^{\circ} \mathrm{C}$ with shaking, no $\mathrm{CO}_{2}$

Subculture Conditions: AA30 or UU30

Sample Preparation: boiled in water $\mathrm{pH} 1.5$, then boiled in Laemelli buffer

SDS-PAGE: $15 \%$ PAGE; 130V, 90 minutes

Transfer: $100 \mathrm{~V} ; 60$ minutes at room temperature

Blocking: TBST with $5 \%$ non-fat milk; overnight at $4{ }^{\circ} \mathrm{C}$

$\mathbf{1}^{\circ}$ Antibody: Batch $2 \alpha$-EcpA (1:1000 in TBST with 5\% BSA); 60 minutes at room temperature then overnight at $4^{\circ} \mathrm{C}$

$\mathbf{2}^{\circ}$ Antibody: Horseradish peroxidase conjugated goat-anti-rabbit $(1: 10,000$

in TBST); 60 minutes at room temperature 


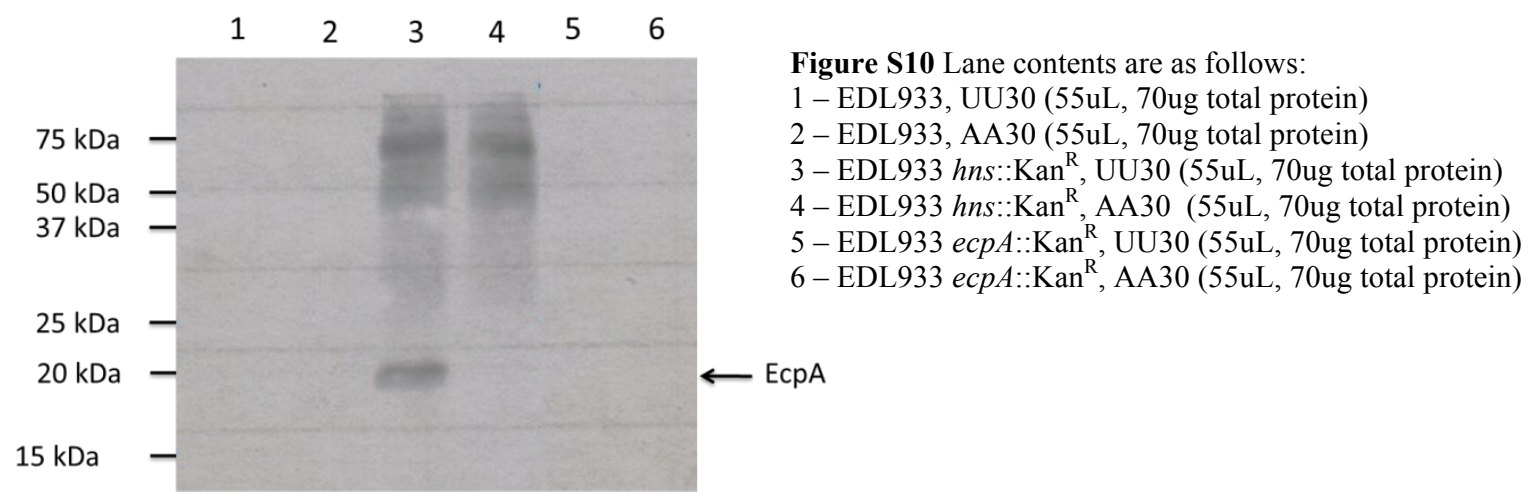

Overnight Growth Conditions: $\mathrm{LB} ; 37^{\circ} \mathrm{C}$ with shaking, no $\mathrm{CO}_{2}$

Subculture Conditions: AA30 or UU30

Sample Preparation: boiled in water $\mathrm{pH} 1.5$, then boiled in Laemelli buffer

SDS-PAGE: 15\% PAGE; 130V, 90 minutes

Transfer: $30 \mathrm{~V} ; 12$ hours at $4^{\circ} \mathrm{C}$

Blocking: TBST with 5\% non-fat milk; overnight at $4{ }^{\circ} \mathrm{C}$

$1^{\circ}$ Antibody: Batch $2 \alpha$-EcpA (1:1000 in TBST with 5\% BSA); 60 minutes at room temperature then overnight at $4^{\circ} \mathrm{C}$

$\mathbf{2}^{\circ}$ Antibody: Horseradish peroxidase conjugated goat-anti-rabbit $(1: 10,000$ in

TBST); 60 minutes at room temperature

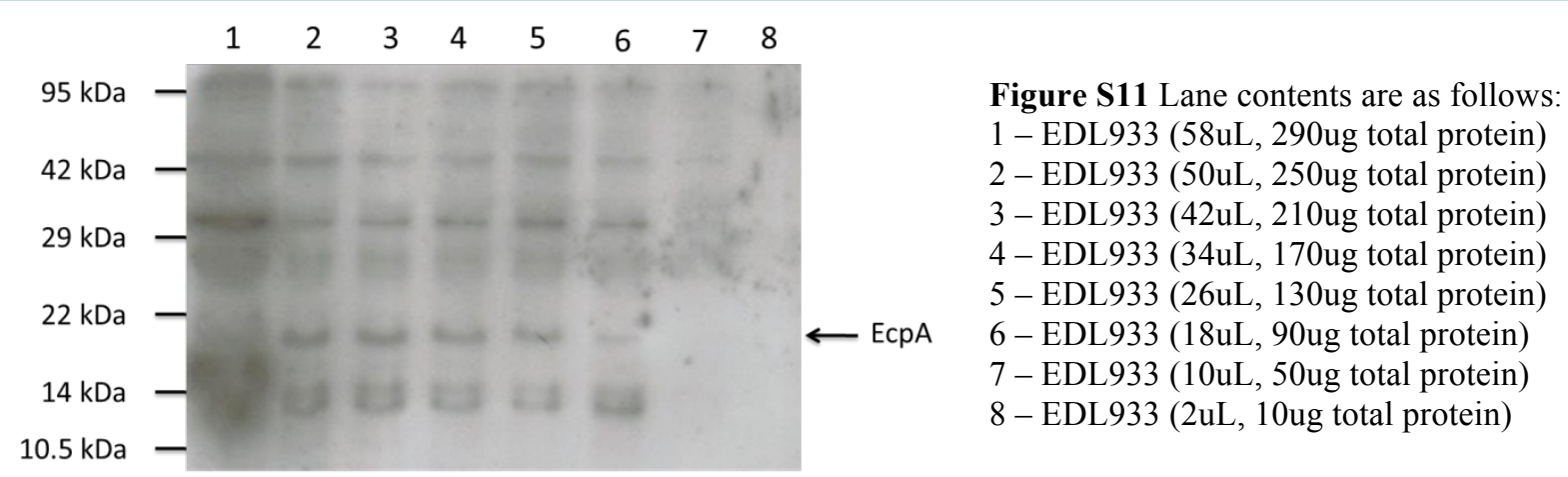

Initial Growth Conditions: $\mathrm{LB} ; 37^{\circ} \mathrm{C}$ with shaking, no $\mathrm{CO}_{2}$

Subculture Conditions: DMEM, $26^{\circ} \mathrm{C}$ static, no $\mathrm{CO}_{2}$

Sample Preparation: boiled in water $\mathrm{pH} 1.5$, then boiled in Laemelli buffer

SDS-PAGE: $15 \%$ PAGE; $130 \mathrm{~V}, 90$ minutes

Transfer: $30 \mathrm{~V} ; 12$ hours at $4^{\circ} \mathrm{C}$

Blocking: TBST with 5\% non-fat milk; overnight at $4{ }^{\circ} \mathrm{C}$

$1^{\circ}$ Antibody: Batch $2 \alpha$-EcpA (1:500 in TBST with 5\% non-fat milk); 60 minutes at room temperature then overnight at $4^{\circ} \mathrm{C}$

$2^{\circ}$ Antibody: Horseradish peroxidase conjugated goat-anti-rabbit $(1: 10,000$

in TBST); 60 minutes at room temperature 


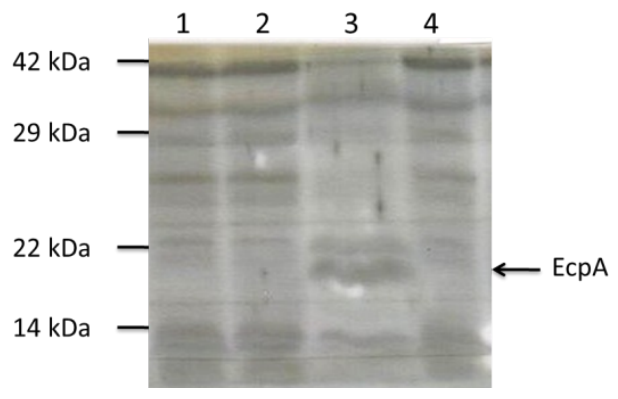

Figure S12 Lane contents are as follows: 1 - EDL933 (16.8uL, 90ug total protein)

2 - EDL933 ecp $A:: \operatorname{Kan}^{\mathrm{R}}$ (15.1uL, 90ug total protein)

3 - EDL933 $h n s:: \operatorname{Kan}^{\mathrm{R}}$ (75.7uL, 90ug total protein)

4 - EDL933 $u v r Y:: \operatorname{Kan}^{\mathrm{R}}$ (14.2uL, 90ug total protein)

Overnight Growth Conditions: $\mathrm{LB} ; 37^{\circ} \mathrm{C}$ with shaking, no $\mathrm{CO}_{2}$

Subculture Conditions: DMEM, $26^{\circ} \mathrm{C}$ static, 7 hours

Sample Preparation: boiled in water $\mathrm{pH} 1.5$, then boiled in Laemelli buffer

SDS-PAGE: $12.5 \%$ PAGE; $125 \mathrm{~V}, 120$ minutes

Transfer: $30 \mathrm{~V} ; 12$ hours at $4^{\circ} \mathrm{C}$

Blocking: TBST with $5 \%$ non-fat milk; overnight at $4{ }^{\circ} \mathrm{C}$

$1^{\circ}$ Antibody: Batch $2 \alpha$-EcpA (1:500 in TBST with 5\% non-fat milk); 60 minutes at room temperature then overnight at $4^{\circ} \mathrm{C}$

$2^{\circ}$ Antibody: Horseradish peroxidase conjugated goat-anti-rabbit $(1: 10,000$

in TBST); 60 minutes at room temperature

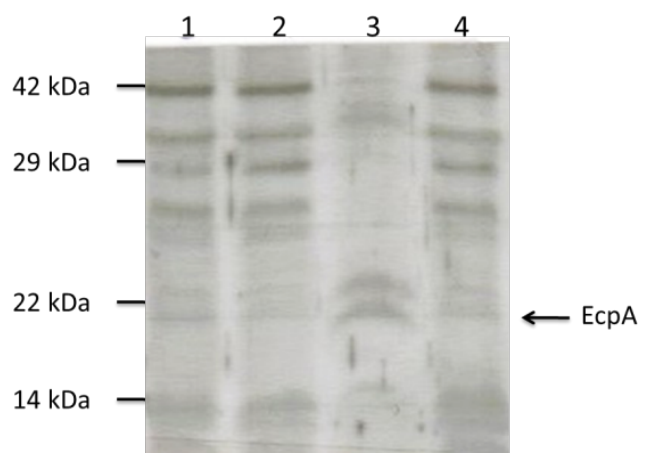

Figure S13 Lane contents are as follows:

1 - EDL933 (15.6uL, 90ug total protein)

2 - EDL933 ecpA::Kan ${ }^{\mathrm{R}}$ (16uL, 90ug total protein)

3 - EDL933 hns::Kan ${ }^{\mathrm{R}}$ (73uL, 90ug total protein)

4 - EDL933 uvrY::Kan ${ }^{\mathrm{R}}$ (14.6uL, 90ug total protein)

Overnight Growth Conditions: $\mathrm{LB} ; 37^{\circ} \mathrm{C}$ with shaking, no $\mathrm{CO}_{2}$

Subculture Conditions: DMEM, $26^{\circ} \mathrm{C}$ static, 7 hours

Sample Preparation: boiled in water $\mathrm{pH} 1.5$, then boiled in Laemelli buffer

SDS-PAGE: $12.5 \%$ PAGE; $125 \mathrm{~V}, 120$ minutes

Transfer: $30 \mathrm{~V} ; 12$ hours at $4^{\circ} \mathrm{C}$

Blocking: TBST with $5 \%$ non-fat milk; overnight at $4{ }^{\circ} \mathrm{C}$

$1^{\circ}$ Antibody: Batch $2 \alpha$-EcpA (1:500 in TBST with 5\% non-fat milk); 60

minutes at room temperature then overnight at $4^{\circ} \mathrm{C}$

$\mathbf{2}^{\circ}$ Antibody: Horseradish peroxidase conjugated goat-anti-rabbit (1:10,000

in TBST); 60 minutes at room temperature 


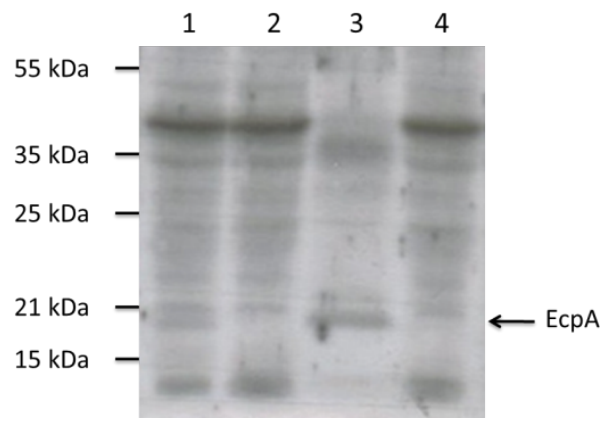

Figure S14 Lane contents are as follows:

1 - EDL933 (14.7uL, 90ug total protein)

2 - EDL933 ecpA::Kan ${ }^{\mathrm{R}}$ (15.1uL, 90ug total protein)

3 - EDL933 hns::Kan ${ }^{\mathrm{R}}(66.8 \mathrm{uL}$, 90ug total protein)

4 - EDL933 uvrY::Kan ${ }^{\mathrm{R}}$ (14.6uL, 90ug total protein)

Overnight Growth Conditions: $\mathrm{LB} ; 37^{\circ} \mathrm{C}$ with shaking, no $\mathrm{CO}_{2}$

Subculture Conditions: DMEM, $26^{\circ} \mathrm{C}$ static, 11 hours

Sample Preparation: boiled in water $\mathrm{pH} 1.5$, then boiled in Laemelli buffer

SDS-PAGE: $12.5 \%$ PAGE; $125 \mathrm{~V}, 120$ minutes

Transfer: $30 \mathrm{~V} ; 12$ hours at $4{ }^{\circ} \mathrm{C}$

Blocking: TBST with $5 \%$ non-fat milk; overnight at $4{ }^{\circ} \mathrm{C}$

$1^{\circ}$ Antibody: Batch $2 \alpha$-EcpA (1:500 in TBST with 5\% non-fat milk); 60 minutes at room temperature then overnight at $4^{\circ} \mathrm{C}$

$\mathbf{2}^{\circ}$ Antibody: Horseradish peroxidase conjugated goat-anti-rabbit $(1: 10,000$

in TBST); 60 minutes at room temperature

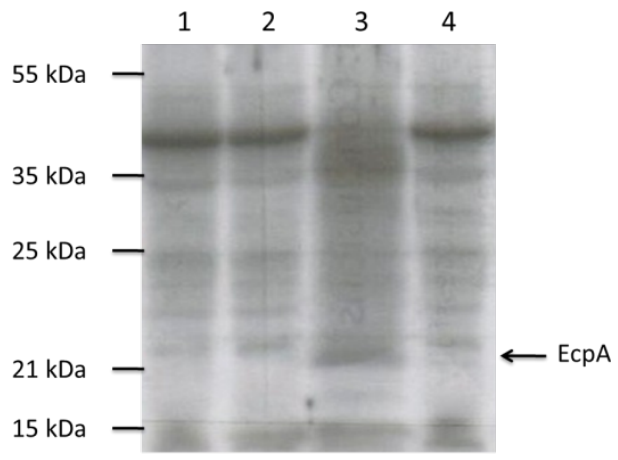

Figure S15 Lane contents are as follows:

1 - EDL933 (24.6uL, 90ug total protein)

2 - EDL933 ecpA::Kan ${ }^{\mathrm{R}}$ (19.6uL, 90ug total protein)

3 - EDL933 hns::Kan ${ }^{\mathrm{R}}$ (70uL, 90ug total protein)

4 - EDL933 $u v r Y:: \operatorname{Kan}^{\mathrm{R}}$ (16.5uL, 90ug total protein)

Overnight Growth Conditions: $\mathrm{LB} ; 37^{\circ} \mathrm{C}$ with shaking, no $\mathrm{CO}_{2}$

Subculture Conditions: DMEM, $26^{\circ} \mathrm{C}$ static, 11 hours

Sample Preparation: boiled in water $\mathrm{pH} 1.5$, then boiled in Laemelli buffer

SDS-PAGE: $12.5 \%$ PAGE; $125 \mathrm{~V}, 120$ minutes

Transfer: $30 \mathrm{~V} ; 12$ hours at $4^{\circ} \mathrm{C}$

Blocking: TBST with $5 \%$ non-fat milk; overnight at $4{ }^{\circ} \mathrm{C}$

$\mathbf{1}^{\circ}$ Antibody: Batch $2 \alpha$-EcpA (1:500 in TBST with 5\% non-fat milk); 60

minutes at room temperature then overnight at $4{ }^{\circ} \mathrm{C}$

$\mathbf{2}^{\circ}$ Antibody: Horseradish peroxidase conjugated goat-anti-rabbit $(1: 10,000$

in TBST); 60 minutes at room temperature 


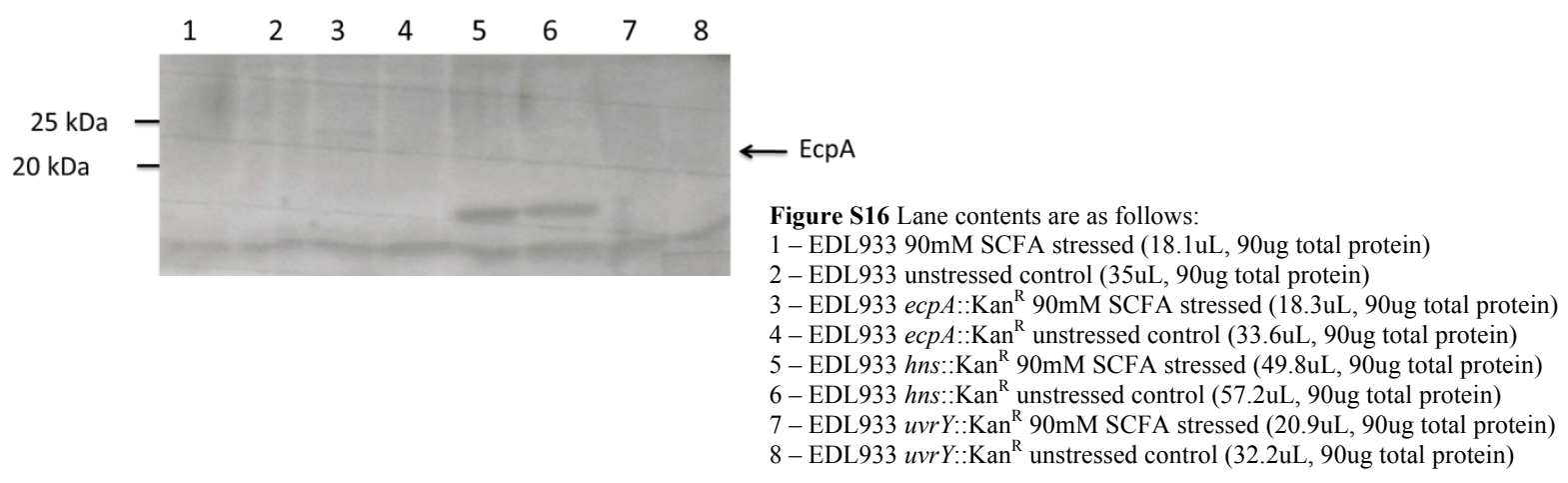

Overnight Growth Conditions: $\mathrm{LB} ; 37^{\circ} \mathrm{C}$ with shaking, no $\mathrm{CO}_{2}$

Subculture Conditions: $90 \mathrm{mM}$ SCFA stress or unstressed control

Sample Preparation: boiled in water $\mathrm{pH} 1.5$, then boiled in Laemelli buffer

SDS-PAGE: $12.5 \%$ PAGE; $150 \mathrm{~V}, 75$ minutes

Transfer: $30 \mathrm{~V} ; 12$ hours at $4^{\circ} \mathrm{C}$

Blocking: TBST with $5 \%$ non-fat milk; overnight at $4{ }^{\circ} \mathrm{C}$

$1^{\circ}$ Antibody: Batch $2 \alpha$-EcpA (1:500 in TBST with 5\% non-fat milk); 60

minutes at room temperature then overnight at $4{ }^{\circ} \mathrm{C}$

$2^{\circ}$ Antibody: Horseradish peroxidase conjugated goat-anti-rabbit $(1: 10,000$

in TBST); 60 minutes at room temperature

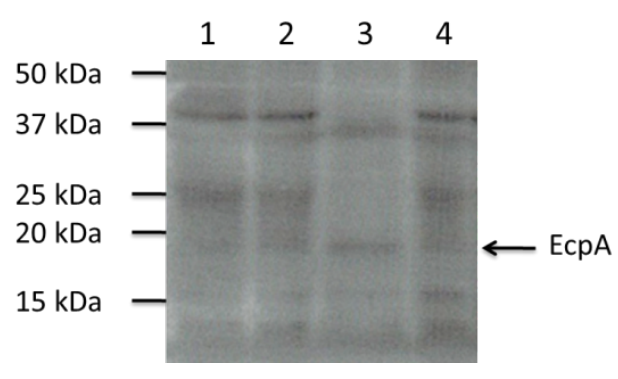

Figure S17 Lane contents are as follows:

1 - EDL933 (14.7uL, 90ug total protein)

2 - EDL933 ecpA::Kan ${ }^{\mathrm{R}}$ (15.1uL, 90ug total protein)

3 - EDL933 hns::Kan ${ }^{\mathrm{R}}$ (55uL, 90ug total protein)

4 - EDL933 $u v r Y:: \operatorname{Kan}^{\mathrm{R}}$ (14.6, 90ug total protein)

Overnight Growth Conditions: $\mathrm{LB} ; 37^{\circ} \mathrm{C}$ with shaking, no $\mathrm{CO}_{2}$

Subculture Conditions: DMEM, $26^{\circ} \mathrm{C}$ static, 11 hours

Sample Preparation: boiled in water $\mathrm{pH} 1.5$, then boiled in Laemelli buffer

SDS-PAGE: $12.5 \%$ PAGE; $125 \mathrm{~V}, 120$ minutes

Transfer: $30 \mathrm{~V} ; 12$ hours at $4{ }^{\circ} \mathrm{C}$

Blocking: TBST with $5 \%$ non-fat milk; overnight at $4{ }^{\circ} \mathrm{C}$

$1^{\circ}$ Antibody: Batch $3 \alpha$-EcpA (1:3000 in PBST with 5\% non-fat milk); 60 minutes at room temperature then overnight at $4^{\circ} \mathrm{C}$

$\mathbf{2}^{\circ}$ Antibody: Horseradish peroxidase conjugated goat-anti-rabbit (1:10,000 in TBST); 60 minutes at room temperature 


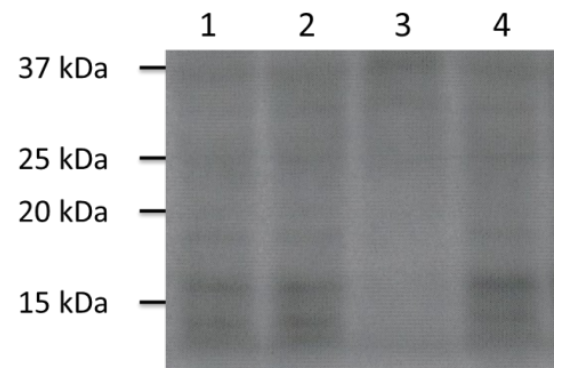

Figure S18 Lane contents are as follows:

1 - EDL933 (14.7uL, 90ug total protein)

2 - EDL933 ecpA::Kan ${ }^{\mathrm{R}}$ (15.1uL, 90ug total protein)

3 - EDL933 hns::Kan ${ }^{\mathrm{R}}$ (55uL, 90ug total protein)

$4-\operatorname{EDL933} u v r Y:: \operatorname{Kan}^{\mathrm{R}}$ (14.6, 90ug total protein)

Overnight Growth Conditions: $\mathrm{LB} ; 37^{\circ} \mathrm{C}$ with shaking, no $\mathrm{CO}_{2}$

Subculture Conditions: DMEM, $26^{\circ} \mathrm{C}$ static, 11 hours

Sample Preparation: boiled in water $\mathrm{pH} 1.5$, then boiled in Laemelli buffer

SDS-PAGE: $12.5 \%$ PAGE; $125 \mathrm{~V}, 120$ minutes

Transfer: $30 \mathrm{~V} ; 12$ hours at $4{ }^{\circ} \mathrm{C}$

Blocking: TBST with $5 \%$ non-fat milk; overnight at $4{ }^{\circ} \mathrm{C}$

$1^{\circ}$ Antibody: $\alpha$-ECP (1:3000 in PBST with 5\% non-fat milk); 60 minutes at room temperature then overnight at $4^{\circ} \mathrm{C}$

$2^{\circ}$ Antibody: Horseradish peroxidase conjugated goat-anti-rabbit $(1: 10,000$

in TBST); 60 minutes at room temperature 


\section{References}

1. Andoh, A., Tsujikawa, T., \& Fujiyama, Y. (2003). Role of dietary fiber and short-chain fatty acids in the colon. Current Pharmaceutical Design, 9(4), 347-358.

2. Atlung, T., \& Ingmer, H. (1997). H-NS: A modulator of environmentally regulated gene expression. Molecular Microbiology, 24(1), 7-17.

3. Audia, J., Webb, C., \& Foster, J. (2001). Breaking through the acid barrier: An orchestrated response to proton stress by enteric bacteria. International Journal of Medical Microbiology, 291(2), 97-106.

4. Avelino, F., Saldaña, Z., Islam, S., Monteiro-Neto, V., Dall'Agnol, M., Eslava, C. A., et al. (2010). The majority of enteroaggregative Escherichia coli strains produce the E. coli common pilus when adhering to cultured epithelial cells. International Journal of Medical Microbiology, 300(7), 440-448.

5. Baik, H., Bearson, S., Dunbar, S., \& Foster, J. (1996). The acid tolerance response of Salmonella typhimurium provides protection against organic acids. Microbiology-Uk, 142, 3195-3200.

6. Bearson, S., Bearson, B., \& Foster, J. W. (1997). Acid stress responses in enterobacteria. FEMS Microbiology Letters, 147(2), 173-180.

7. Besser, R. E., Griffin, P. M., \& Slutsker, L. (1999). Escherichia coli 0157:H7 gastroenteritis and the hemolytic uremic syndrome: An emerging infectious disease

8. Blackburn, D., Husband, A., Saldaña, Z., Nada, R. A., Klena, J., Qadri, F., et al. (2009). Distribution of the Escherichia coli common pilus among diverse strains of human enterotoxigenic E. coli. Journal of Clinical Microbiology, 47(6), 1781-1784. 
9. Capitani, G., Eidam, O., Glockshuber, R., \& Grütter, M. G. (2006). Structural and functional insights into the assembly of type 1 pili from Escherichia coli. Microbes and Infection, 8(8), 2284-2290.

10. Casadaban, M. J., Chou, J., \& Cohen, S. N. (1980). In vitro gene fusions that join an enzymatically active beta-galactosidase segment to amino-terminal fragments of exogenous proteins: Escherichia coli plasmid vectors for the detection and cloning of translational initiation signals. Journal of Bacteriology, 143(2), 971-980.

11. Cassin, M. H., Lammerding, A. M., Todd, E. C. D., Ross, W., \& McColl, R. S. (1998). Quantitative risk assessment for Escherichia coli O157:H7 in ground beef hamburgers. International Journal of Food Microbiology, 41(1), 21-44.

12. Chavez, R. G., Alvarez, A. F., Romeo, T., \& Georgellis, D. (2010). The physiological stimulus for the BarA sensor kinase. Journal of Bacteriology, 192(7), 2009-2012.

13. Cohen, M. B., \& Giannella, R. A. (1992). Hemorrhagic colitis associated with Escherichia coli O157:H7. Advances in Internal Medicine, 37, 173-195.

14. Corcoran, C. P., \& Dorman, C. J. (2009). DNA relaxation-dependent phase biasing of the fim genetic switch in Escherichia coli depends on the interplay of H-NS, IHF and LRP. Molecular Microbiology, 74(5), 1071-1082.

15. Cummings, J. H. (1981). Short chain fatty-acids in the human-colon. Gut, 22(9), 763-779.

16. Datsenko, K. A., \& Wanner, B. L. (2000). One-step inactivation of chromosomal genes in Escherichia coli K-12 using PCR products. Proceedings of the National Academy of Sciences of the United States of America, 97(12), 6640-6645.

17. Dean, P., Maresca, M., \& Kenny, B. (2005). EPEC's weapons of mass subversion. Current Opinion in Microbiology, 8(1), 28-34. 
18. Erol, I., Jeong, K. -., Baumler, D. J., Vykhodets, B., Sang, H. C., \& Kaspar, C. W. (2006). HNS controls metabolism and stress tolerance in Escherichia coli O157:H7 that influence mouse passage. BMC Microbiology, 6

19. Foster, J. W. (1999). When protons attack: Microbial strategies of acid adaptation. Current Opinion in Microbiology, 2(2), 170-174.

20. Foster, J. W. (2004). Escherichia coli acid resistance: Tales of an amateur acidophile. Nature Reviews Microbiology, 2(11), 898-907.

21. Fukuda, S., Toh, H., Hase, K., Oshima, K., Nakanishi, Y., Yoshimura, K., et al. (2011). Bifidobacteria can protect from enteropathogenic infection through production of acetate. Nature, 469(7331), 543-549.

22. Galán, J. E., \& Wolf-Watz, H. (2006). Protein delivery into eukaryotic cells by type III secretion machines. Nature, 444(7119), 567-573.

23. Garmendia, J., Frankel, G., \& Crepin, V. F. (2005). Enteropathogenic and enterohemorrhagic Escherichia coli infections: Translocation, translocation, translocation. Infection and Immunity, 73(5), 2573-2585.

24. Garnett, J. A., Martínez-Santos, V. I., Saldaña, Z., Pape, T., Hawthorne, W., Chan, J., et al. (2012). Structural insights into the biogenesis and biofilm formation by the Escherichia coli common pilus. Proceedings of the National Academy of Sciences of the United States of America, 109(10), 3950-3955.

25. Guilloteau, P., Martin, L., Eeckhaut, V., Ducatelle, R., Zabielski, R., \& Van Immerseel, F. (2010). From the gut to the peripheral tissues: The multiple effects of butyrate. Nutrition Research Reviews, 23(2), 366-384.

26. Hall, H. K., Karem, K. L., \& Foster, J. W. (1995). Molecular responses of microbes to environmental pH stress. Advances in Microbial Physiology, 37, 229-272. 
27. Haque, S. (2010). Role of selected fimbrial adhesins in pathogenesis of acid-induced enterohemorrhagic Escherichia coli O157:H7. Unpublished master's thesis, Ryerson University, Toronto, Ontario.

28. Hayashi, T., Makino, K., Ohnishi, M., Kurokawa, K., Ishii, K., Yokoyama, K., et al. (2001). Complete genome sequence of enterohemorrhagic Escherichia coli O157:H7 and genomic comparison with a laboratory strain K-12. DNA Research, 8(1), 11-22.

29. Hengge, R. (2008). The two-component network and the general stress sigma factor RpoS $(\sigma S)$ in Escherichia coli

30. Herold, S., Paton, J. C., Srimanote, P., \& Paton, A. W. (2009). Differential effects of shortchain fatty acids and iron on expression of iha in shiga-toxigenic Escherichia coli. Microbiology, 155(11), 3554-3563.

31. House, B., Kus, J. V., Prayitno, N., Mair, R., Que, L., Chingcuanco, F., et al. (2009). Acidstress-induced changes in enterohaemorrhagic Escherichia coli O157: H7 virulence. Microbiology, 155(9), 2907-2918.

32. Hultgren, S. J., Abraham, S., Caparon, M., Falk, P., St. Geme III, J. W., \& Normark, S. (1993). Pilus and nonpilus bacterial adhesins: Assembly and function in cell recognition. Cell, 73(5), 887-901.

33. Hultgren, S. J., Normark, S., \& Abraham, S. N. (1991). Chaperone-assisted assembly and molecular architecture of adhesive pili. Annual Review of Microbiology, 45, 383-415.

34. Jackson, D. W., Suzuki, K., Oakford, L., Simecka, J. W., Hart, M. E., \& Romeo, T. (2002). Biofilm formation and dispersal under the influence of the global regulator CsrA of Escherichia coli. Journal of Bacteriology, 184(1), 290-301.

35. Jonas, K., \& Melefors, O. (2009). The Escherichia coli CsrB and CsrC small RNAs are strongly induced during growth in nutrient-poor medium. FEMS Microbiology Letters, 297(1), 80-86. 
36. Kawula, T. H., \& Orndorff, P. E. (1991). Rapid site-specific DNA inversion in Escherichia coli mutants lacking the histonelike protein H-NS. Journal of Bacteriology, 173(13), 41164123.

37. King, T., Lucchini, S., Hinton, J. C. D., \& Gobius, K. (2010). Transcriptomic analysis of Escherichia coli $\mathrm{O} 157: \mathrm{H} 7$ and K-12 cultures exposed to inorganic and organic acids in stationary phase reveals acidulant- and strain-specific acid tolerance responses. Applied and Environmental Microbiology, 76(19), 6514-6528.

38. Kus, J. V., Gebremedhin, A., Dang, V., Tran, S. -., Serbanescu, A., \& Foster, D. B. (2011). Bile salts induce resistance to polymyxin in enterohemorrhagic Escherichia coli O157:H7. Journal of Bacteriology, 193(17), 4509-4515.

39. Laparra, J. M., \& Sanz, Y. (2010). Interactions of gut microbiota with functional food components and nutraceuticals. Pharmacological Research, 61(3), 219-225.

40. Lee, J. -., Kim, Y. -., Cho, M. H., Wood, T. K., \& Lee, J. (2011). Transcriptomic analysis for genetic mechanisms of the factors related to biofilm formation in Escherichia coli O157:H7. Current Microbiology, 62(4), 1321-1330.

41. Lehti, T. A., Bauchart, P., Dobrindt, U., Korhonen, T. K., \& Westerlund-Wikström, B. (2012). The fimbriae activator MatA switches off motility in Escherichia coli by repression of the flagellar master operon flhDC. Microbiology (United Kingdom), 158(6), 1444-1455.

42. Lehti, T. A., Bauchart, P., Heikkinen, J., Hacker, J., Korhonen, T. K., Dobrindt, U., et al. (2010). Mat fimbriae promote biofilm formation by meningitis-associated Escherichia coli. Microbiology, 156(8), 2408-2417.

43. Lehti, T. A., Bauchart, P., Kukkonen, M., Dobrindt, U., Korhonen, T. K., \& WesterlundWikström, B. (2013). Phylogenetic group-associated differences in regulation of the common colonization factor mat fimbria in Escherichia coli. Molecular Microbiology, 87(6), 1200-1222. 
44. Li, Z., Bell, C., Buret, A., Robins-Browne, R., Stiel, D., \& O'Loughlin, E. (1993). The effect of enterohemorrhagic Escherichia coli $\mathrm{O} 157: \mathrm{H} 7$ on intestinal structure and solute transport in rabbits. Gastroenterology, 104(2), 467-474.

45. Lim, J. Y., Yoon, J. W., \& Hovde, C. J. (2010). A brief overview of Escherichia coli O157:H7 and its plasmid O157. Journal of Microbiology and Biotechnology, 20(1), 1-10.

46. Low, A. S., Holden, N., Rosser, T., Roe, A. J., Constantinidou, C., Hobman, J. L., et al. (2006). Analysis of fimbrial gene clusters and their expression in enterohaemorrhagic Escherichia coli O157:H7. Environmental Microbiology, 8(6), 1033-1047.

47. Martínez-Santos, V. I., Medrano-López, A., Saldaña, Z., Girón, J. A., \& Puente, J. L. (2012). Transcriptional regulation of the ecp operon by EcpR, IHF, and H-NS in attaching and effacing Escherichia coli. Journal of Bacteriology, 194(18), 5020-5033.

48. Mellies, J. L., Barron, A. M. S., \& Carmona, A. M. (2007). Enteropathogenic and enterohemorrhagic Escherichia coli virulence gene regulation. Infection and Immunity, 75(9), 4199-4210.

49. Miller, J. H. (1972). Experiments in molecular genetics. Cold Spring Harbor, NY: Cold Spring Harbor Laboratory.

50. Momose, Y., Hirayama, K., \& Itoh, K. (2008). Effect of organic acids on inhibition of Escherichia coli $\mathrm{O} 157$ : H7 colonization in gnotobiotic mice associated with infant intestinal microbiota. Antonie Van Leeuwenhoek International Journal of General and Molecular Microbiology, 93(1-2), 141-149.

51. Mondragón, V., Franco, B., Jonas, K., Suzuki, K., Romeo, T., Melefors, Ö., et al. (2006). $\mathrm{pH}$-dependent activation of the BarA-UvrY two-component system in Escherichia coli. Journal of Bacteriology, 188(23), 8303-8306.

52. Moxley, R. A. (2004). Escherichia coli 0157:H7: An update on intestinal colonization and virulence mechanisms. Animal Health Research Reviews / Conference of Research Workers in Animal Diseases, 5(1), 15-33. 
53. Müller, C. M., Dobrindt, U., Nagy, G., Emödy, L., Uhlin, B. E., \& Hacker, J. (2006). Role of histone-like proteins H-NS and StpA in expression of virulence determinants of uropathogenic Escherichia coli. Journal of Bacteriology, 188(15), 5428-5438.

54. Nakanishi, N., Tashiro, K., Kuhara, S., Hayashi, T., Sugimoto, N., \& Tobe, T. (2009). Regulation of virulence by butyrate sensing in enterohaemorrhagic Escherichia coli. Microbiology, 155(2), 521-530.

55. Pernestig, A.-K., Melefors, Ö., \& Georgellis, D. (2001). Identification of UvrY as the cognate response regulator for the BarA sensor kinase in Escherichia coli. Journal of Biological Chemistry, 276(1), 225-231.

56. Pizarro-Cerdá, J., \& Cossart, P. (2006). Bacterial adhesion and entry into host cells. Cell, 124(4), 715-727.

57. Pouttu, R., Westerlund-Wikström, B., Lång, H., Alsti, K., Virkola, R., Saarela, U., et al. (2001). matB, a common fimbrillin gene of Escherichia coli, expressed in a genetically conserved, virulent clonal group. Journal of Bacteriology, 183(16), 4727-4736.

58. Rendón, M. A., Saldaña, Z., Erdem, A. L., Monteiro-Neto, V., Vázquez, A., Kaper, J. B., et al. (2007). Commensal and pathogenic Escherichia coli use a common pilus adherence factor for epithelial cell colonization. Proceedings of the National Academy of Sciences of the United States of America, 104(25), 10637-10642.

59. Richard, H. T., \& Foster, J. W. (2003). Acid resistance in Escherichia coli

60. Ricke, S. (2003). Perspectives on the use of organic acids and short chain fatty acids as antimicrobials. Poultry Science, 82(4), 632-639.

61. Riley, L. W., Remis, R. S., \& Helgerson, S. D. (1983). Hemmorhagic colitis associated with a rare Escherichia coli serotype. New England Journal of Medicine, 308(12), 681-685. 
62. Rogers, M. T., Zimmerman, R., \& Scott, M. E. (2009). Histone-like nucleoid-structuring protein represses transcription of the ehx operon carried by locus of enterocyte effacementnegative shiga toxin-expressing Escherichia coli. Microbial Pathogenesis, 47(4), 202-211.

63. Roy, C. C., Kien, C. L., Bouthillier, L., \& Levy, E. (2006). Short-chain fatty acids: Ready for prime time? Nutrition in Clinical Practice : Official Publication of the American Society for Parenteral and Enteral Nutrition, 21(4), 351-366.

64. Saldaña, Z., Erdem, A. L., Schüller, S., Okeke, I. N., Lucas, M., Sivananthan, A., et al. (2009). The Escherichia coli common pilus and the bundle-forming pilus act in concert during the formation of localized adherence by enteropathogenic E. coli. Journal of Bacteriology, 191(11), 3451-3461.

65. Sarkar, T., Petrov, A. S., Vitko, J. R., Santai, C. T., Harvey, S. C., Mukerji, I., et al. (2009). Integration host factor (IHF) dictates the structure of polyamine-DNA condensates: Implications for the role of IHF in the compaction of bacterial chromatin. Biochemistry, 48(4), 667-675.

66. Schmidt, M. A. (2010). LEEways: Tales of EPEC, ATEC and EHEC. Cellular Microbiology, 12(11), 1544-1552.

67. Serbanescu, M.A. (2008) Virulence response of Escherichia coli O157:H7 to bile salts and short chain fatty acids. Unpublished master's thesis, Ryerson University, Toronto, Ontario.

68. Suzuki, K., Wang, X., Weilbacher, T., Pernestig, A. -., Melefors, Ö., Georgellis, D., et al. (2002). Regulatory circuitry of the CsrA/CsrB and BarA/UvrY systems of Escherichia coli. Journal of Bacteriology, 184(18), 5130-5140.

69. Tendeng, C., \& Bertin, P. N. (2003). H-NS in gram-negative bacteria: A family of multifaceted proteins. Trends in Microbiology, 11(11), 511-518.

70. Timmermans, J., \& Van Melderen, L. (2010). Post-transcriptional global regulation by CsrA in bacteria. Cellular and Molecular Life Sciences, 67(17), 2897-2908. 
71. Tobe, T., Nakanishi, N., \& Sugimoto, N. (2011). Activation of motility by sensing shortchain fatty acids via two steps in a flagellar gene regulatory cascade in enterohemorrhagic Escherichia coli. Infection and Immunity, 79(3), 1016-1024.

72. Tomenius, H., Pernestig, A. - K., Jonas, K., Georgellis, D., Möllby, R., Normark, S., et al. (2006). The Escherichia coli BarA-UvrY two-component system is a virulence determinant in the urinary tract. BMC Microbiology, 6

73. Torres, A. G., López-Sánchez, G. N., Milflores-Flores, L., Patel, S. D., Rojas-López, M., Martínez De La Peña, C. F., et al. (2007). Ler and H-NS, regulators controlling expression of the long polar fimbriae of Escherichia coli O157:H7. Journal of Bacteriology, 189(16), 5916-5928.

74. Torres, A. G., Slater, T. M., Patel, S. D., Popov, V. L., \& Arenas-Hernández, M. M. P. (2008). Contribution of the ler- and H-NS-regulated long polar fimbriae of Escherichia coli O157:H7 during binding to tissue-cultured cells. Infection and Immunity, 76(11), 50625071.

75. Torres, A. G., Zhou, X., \& Kaper, J. B. (2005). Adherence of diarrheagenic Escherichia coli strains to epithelial cells. Infection and Immunity, 73(1), 18-29.

76. Tutukina, M. N., Shavkunov, K. S., Masulis, I. S., \& Ozoline, O. N. (2010). Antisense transcription within the hns locus of Escherichia coli. Molecular Biology, 44(3), 439-447.

77. Waterman, S. R., \& Small, P. L. C. (2003). Transcriptional expression of Escherichia coli glutamate-dependent acid resistance genes gadA and gadBC in an hns rpoS mutant. Journal of Bacteriology, 185(15), 4644-4647.

78. Whittam, T. S., \& Wilson, R. A. (1988). Genetic relationships among pathogenic Escherichia coli of serogroup O157. Infection and Immunity, 56(9), 2467-2473.

79. Williams, R. M., \& Rimsky, S. (1997). Molecular aspects of the E. coli nucleoid protein, HNS: A central controller of gene regulatory networks. FEMS Microbiology Letters, 156(2), 175-185. 
80. Wong, J. M. W., de Souza, R., Kendall, C. W. C., Emam, A., \& Jenkins, D. J. A. (2006).

Colonic health: Fermentation and short chain fatty acids. Journal of Clinical Gastroenterology, 40(3), 235-243.

81. Yamada, H., Muramatsu, S., \& Mizuno, T. (1990). An Escherichia coli protein that preferentially binds to sharply curved DNA. Journal of Biochemistry, 108(3), 420-425.

82. Yu, Y. (2011) Characterization of the role of yadK in the pathogenesis of enterohaemorrhagic E. coli O157:H7. Unpublished master's thesis, Ryerson University, Toronto, Ontario.

83. Zhang, X., \& Bremer, H. (1995). Control of the Escherichia coli rrnB P1 promoter strength by ppGpp. Journal of Biological Chemistry, 270(19), 11181-11189. 